Informal Report

Mineralogy and Petrology of Tuff Units from the UE25a-1 Drill Site, Yucca Mountain, Nevada 
LA-8139-MS

Informal Report

UC-70

Issued: November 1979

\section{Mineralogy and Petrology of Tuff Units from the UE25a-1 Drill Site, Yucca Mountain, Nevada}

Martha L. Sykes

Grant H. Heiken Joseph R. Smyth 
MINERALOGY AND PETROLOGY OF TUFF UNITS FROM THE UE25a-1 DRILL SITE, YUCCA
MOUNTAIN, NEVADA

by

Martha L. Sykes, Grant H. Heiken, and Joseph R. Smyth

\section{ABSTRACT}

Thick sequences of zeolitized tuff may form effective natural harriers against ground water migration of radionuclides from radioactive waste isolation facilities. In the Yucca Mountain area of the Nevada Tesi Site, a location under investigation for such a facility, drill hole UE25a-1 has penetrated tuffs of Tertiary age which contain two major zeolitized horizons at depths below $380 \mathrm{~m}$. These horizons are restricted to low density, high porosity nonwelded tuffs below the basal vitrophyre of the Topopah Springs Member of the Paintbrush Tuff (approximately $70 \mathrm{~m}$ above the current water table), and interfinger with more-densely-welded devitrified tuffs of grancphyric mineralogy. Zeolites occur as glass pyroclast replacement, vug linings, and fracture fillings. Nonwelded units above the weided portion of the Topopah Springs Member are essentially unaltered, indicating that they have never been ground water-saturated for any significant length of time.

Zeolite mineral assemblages appear to be characteristic of low temperature $\left(<100^{\circ} \mathrm{C}\right)$ ground water alteration of glass in an open hydrologic system. The principal zeolite phase is high-Si clinoptilolite with Si/Al ratios of 4.7 to 6.0 . $\mathrm{Ca}$ tends to be the dominant 1 arge-radius cation, but grains with dominant $\mathrm{K}$ or $\mathrm{Na}$ are not uncommon, particularly with increasing depth. Compositional variations in clinoptilo1 ite may be due to ground water composition or original pyroclast composition.

Minor amounts of mordenite, characterized by lower silica content ( $<55 \mathrm{wt} \%)$ and high alkali content $(>10 \mathrm{wt} \%$ $\mathrm{Na}_{2} \mathrm{O}+\mathrm{K}_{2} \mathrm{O}$ ), occur as vug fillings at depths below $500 \mathrm{~m}$. Presence of mordenite may indicate slightly elevated alteration temperatures, but more likely reflects enrichment of ground water in alkal is with depth.

Mineralogical, compositional, and textural similarities of the zeolitized tuffs from UE25a-1 and J-13 are compatible with a single episode of crystallization. 


\section{INTKODUCTION}

Thick pyroclastic deposits have been proposed as possible repository sites for geologic isolation of radioactive waste (Smyth et al., 1979). Many large volume silicic tuff units have undergone ground water or hydrothermal alteration with glassy material replaced by mixtures of zeolites and several other authigenic minerals. Tuff units composed mainly of secondary zeolite minerals may act as an effective barrier to the movement of buried radioactive waste as some zeolite minerals have high sorptive coefficients for largeradius cations (Smyth et al., 1979).

Within southern Nevada many thousands of cubic kilometers of rhyolitic tephra were erupted and deposited as pyroclastic flows and air-fall units during late Tertiary time. One result of this activity was the formation of the overlapping calderas of the Timber Mountain-Oasis Valley Caldera Complex. This volcanic field was developed on fairly low relief topography probably associated with basin-range normal faulting (Byers et al., 1976; Christiansen et al., 1977). Cumulative maximum thickness of the tuff sequences may locally exceed three thousand meters. The tuff units and calderas, ranging in age from 16 - 9 m.y., have been mapped and described in detail by Byers et al. (1976) and Christiansen et al. (1977) at the U.S. Geological Survey.

Exploratory drill hole UE25a-1 was drilled into Yucca Mountain tuff to a depth of $762 \mathrm{~m}$, adjacent to the east side of Yucca Mounatin (see Fig. 1; northcentral part of the Topopah Spring SW 7.5' Quadrangle, Nye County, Nevada lat. $36^{\circ} 51^{\prime} 05^{\prime \prime}$, long. $\left.116^{\circ} 26^{\prime} 24^{\prime \prime}\right)$. The drill site is located between north-south trending normal faults and crosses several major faults or fracture systems; fracture surfaces are coated with manganese, silica, iron oxides and calcite (Spengler et al., 1979). For detailed information on the drilling history and background geological data, see Spengler et al . (1979).

Drill hole UE25a-1 penetrated the Paintbrust Tuff, tuffaceous beds of Calico Hills, and the Crater Flat Tuff. The purpose of the drilling was to investigate the stratigraphy, structure, mineralogy, petrology and physical properties of the tuff units. This report will describe the results of the mineralogical and petrological investigations. 


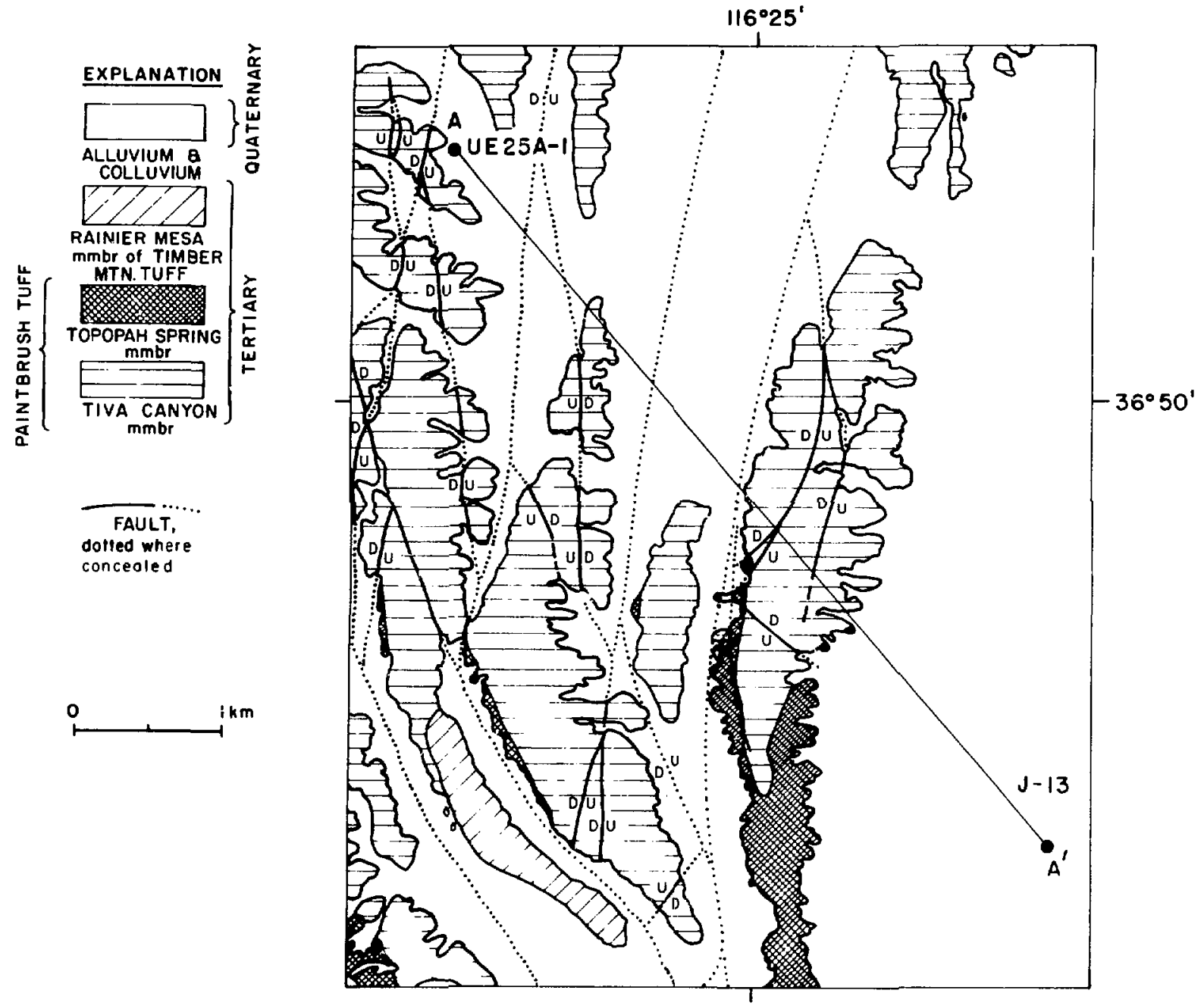

Fig. 1

Generalized geologic map of the Yucca Mountain area, Nevada Test Site, showing positions of drill sites UE25a-1 and J-13 (after Lipman and McKay, 1965).

II. SAMPLES AND ANALYTICAL TECHNIQUES

Core samples were obtained from UE25a-1 for drilling depths of 25.5 $759.3 \mathrm{~m}$; core from 143.0 - 226.8-m depth (YM-10 through -16) was waxed and wrapped, and therefore not available for analysis. Samples $Y M-20$ and -21 , from 206.4 and $223.3-\mathrm{m}$ depth respectively, were later obtained from this interval. 
Doubly polished thin sections cut normai to bedding were made of all samples, and additional sections cut parallel to bedding were prepared for samples $\mathbf{M i}-1$ through -19. Modal analyses were determined using 300 to 500 points. Chemical analyses for individual phases in samples were obtained using a Cameca model CAMEBAX automated electron microprobe. A 10- $\mu \mathrm{m}^{2}$ rastering beam of $15 \mathrm{kV}$ with a beam current of about $1.5 \mathrm{nA}$ was used in most analyses. Average analyses for selected phases are given in the Appendix.

Further phase identifications were made using Debye-Scherrer x-ray powder diffraction. Samples obtained from the cores were run for $6-12$ hours with $\mathrm{Ni}$-filtered $\mathrm{Cu} \mathrm{K} \alpha$ radiatiori. Results are included in Table I and the Appendix.

Bulk densities were obtained on cylinders cut from the UE25a-1 core and dried for 24 hours at $100^{\circ} \mathrm{C}$ (see Table I).

\section{CLASSIFICATION AND TERMINOLOGY}

The terminology used in this report follows that of Fisher (1961) and cook (1965). Fisher's classification (Fig. 2) which is based on grain size, has been in world-wide use for many years. Cook's classification (Fig. 3) is based on relative proportions of vitric, crystal, and lithic pyroclasts (pyroclast being any fragment from explosive volcanic activity). The designation of pyroclastic rocks as 'vitric,' 'vitric-crystal,' etc., is based upon the original nature of the rocks, regardless of the amount of fresh glass remaining. This terminology thus gives the reader some idea of the volume of material that is easily altered during devitrification or by interaction with volatile phases.

To describe welded units that were emplaced as pyroclastic flows we use the term 'pyroclastic flow.' Many authors use the term 'ash fiow,' but since most flows contain abundant coarse pumice pyroclasts (much coarser than 'ash' size) we prefer not to use that term. Also, for samples as restricted as cores, it is difficult to differentiate between air-fall or bedded and nonwelded pyroclastic flow units; we therefore use the term 'nonwelded' for each. 'Tuff' refers to all consolidated pyroclastic deposits and will be used for almost all the units sampled.

The degree of welding in pyroclastic flow units is usually determined for unaltered rocks by density measurements; due to the degree of alteration in these rocks, this procedure may not accurateiy reflect welding variations. We 
TABLE I

AUTHIGENIC MINERALOGY OF UE25a-1 SAMPLES

\begin{tabular}{|c|c|c|c|c|c|}
\hline SAMPLE & STRATIGRAPHIC UNIT & DESCRIPTION & AUTHIGENIC PHASES ${ }^{C}$ & COMPOSITIONS $^{d}$ & COMMENTS \\
\hline $\begin{array}{l}Y M-1 \\
(25.5)^{a}\end{array}$ & $\begin{array}{l}\text { Tiva Canyon member } \\
\text { of the Paintbrush } \\
\text { Tuff }\end{array}$ & $\begin{array}{l}\text { Devitrified densely } \\
\text { welded vitric tuff } \\
\text { with minor vapor } \\
\text { phase crystaliza- } \\
\text { tion (ND) }\end{array}$ & $\begin{array}{l}\text { Fibrous } 1-2 \mu m \text { wide (matrix) } \\
\text { Spherul itic } \leq 750 \mu \mathrm{m} \text { diam } \\
\text { (pumico) } \\
\text { Euhedral tabular } 50-400 \mu \mathrm{m} \\
\text { long (vugs) }\end{array}$ & $\begin{array}{l}\mathrm{Mix} 40 \% \mathrm{Cr}+60 \% \mathrm{KAF} \\
\mathrm{KAF}, \mathrm{Cr}\end{array}$ & \\
\hline $\begin{array}{l}Y M-2 \\
(48.0)\end{array}$ & $"$ & $\begin{array}{l}\text { Devitrified densely } \\
\text { welded vitric tuff } \\
\text { with vapor phase } \\
\text { crystallization(ND) }\end{array}$ & $\begin{array}{l}\text { Granular }<10 \mu \mathrm{m} \text { diam (matrix) } \\
\text { Granular } 20 \mu \mathrm{m} \text { diam (shards) } \\
\text { Spherul itic } 50-150 \mu \mathrm{m} \mathrm{diam} \\
\text { Euhedral equant } 50-100 \mu \mathrm{m} \\
\text { diam (vugs) }\end{array}$ & $\begin{array}{l}\text { Mix } 20 \% \mathrm{Cr}+80 \% \mathrm{KAF} \\
\text { Mix } 40 \% \mathrm{Cr}+60 \% \mathrm{KAF} \\
\mathrm{KAF}, \mathrm{Cr}\end{array}$ & \\
\hline $\begin{array}{l}Y M-3 \\
(57.0)\end{array}$ & $"$ & $\begin{array}{l}\text { Devitrified moder- } \\
\text { ately welded vitric } \\
\text { tuff with minor } \\
\text { vapor phase crys- } \\
\text { tallization (ND) }\end{array}$ & $\begin{array}{l}\text { Fibrous/granular } 1-3 \mu m \text { diam } \\
\text { (matrix) } \\
\text { Fibrous } 1-2 \mu \text { mide (vugs) } \\
\text { Spherulitic: xls } 3-5 \mu m \text { wide; } \\
<200 \mu m \text { long (pumice) }\end{array}$ & $\begin{array}{l}\text { Mix } 40 \% \mathrm{Cr}+60 \% \mathrm{KAF} \\
\operatorname{Mix} 20 \% \mathrm{Cr}+80 \% \mathrm{KAF}\end{array}$ & \\
\hline $\begin{array}{l}Y M-4 \\
(68.9)\end{array}$ & $"$ & $\begin{array}{l}\text { Nonwelded vitric- } \\
\text { crystal tuff (ND) }\end{array}$ & $\begin{array}{l}\text { Hydrated (?) glass at pyro- } \\
\text { clast boundaries }\end{array}$ & NA & Crystal rich \\
\hline $\begin{array}{l}Y M-5 \\
(76.5)\end{array}$ & $"$ & $\begin{array}{l}\text { Non-welded vitric- } \\
\text { crystal tuff (ND) }\end{array}$ & NA & NA & $\begin{array}{l}\text { Pumice, lithic, } \\
\text { and crystal rich }\end{array}$ \\
\hline $\begin{array}{l}Y M-6 \\
(84.3)\end{array}$ & $\begin{array}{l}\text { Topopah Springs } \\
\text { Member of the } \\
\text { Paintbrus. Tuff }\end{array}$ & $\begin{array}{l}\text { Densely welded } \\
\text { vitric-crystal } \\
\text { tuff (ND) }\end{array}$ & NA & NA & Crystal rich \\
\hline $\begin{array}{l}Y M-7 \\
(102.0)\end{array}$ & $"$ & $\begin{array}{l}\text { Devitrified densely } \\
\text { welded vitric- } \\
\text { crystal tuff with } \\
\text { vapor phase crys- } \\
\text { tallization (ND) }\end{array}$ & 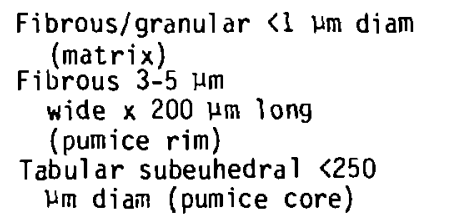 & $\operatorname{Mix} 30 \% \mathrm{Cr}+70 \% \mathrm{KAF}$ & Crystal rich \\
\hline $\begin{array}{l}Y M-8 \\
(137.2)\end{array}$ & $"$ & $\begin{array}{l}\text { Devitrified densely } \\
\text { welded vitric tuff } \\
\text { with minor vapor } \\
\text { phase crystalliza- } \\
\text { tion (ND) }\end{array}$ & $\begin{array}{l}\text { Fibrous }<3 \mu \mathrm{m} \text { diam (matrix) } \\
\text { Granular patches }<40 \mu \mathrm{m} \text { diam }\end{array}$ & $\operatorname{Mix}_{\mathrm{Cr}} 25 \% \mathrm{Cr}+75 \% \mathrm{KAF}$ & \\
\hline $\begin{array}{l}Y M-9 \\
(143.0)\end{array}$ & $"$ & $\begin{array}{l}\text { Devitrified densely } \\
\text { welded vitric tuff } \\
\text { with vapor phase } \\
\text { crystallization (ND) }\end{array}$ & $\begin{array}{l}\text { Fibrous } 1-3 \mu \mathrm{m} \text { wide } \\
\text { (matrix, vug rims) } \\
\text { Spherul ites (pumice) } \\
\text { Granular patches } 30-100 \mu m \\
\text { viam }\end{array}$ & $\begin{array}{l}\text { Mix } 35 \% \mathrm{Cr}+65 \% \mathrm{KAF} \\
\operatorname{Mix} 10 \% \mathrm{Cr}+90 \% \mathrm{KAF} \\
\mathrm{Cr},(\mathrm{KAF})\end{array}$ & \\
\hline
\end{tabular}




$Y M-20$
$(206.4)$
$Y M-21$
$(223.3)$

$Y M-17$
$(226.8)$
$Y M-24$
$(285.7)$
$Y M-18$
$(254.8)$
$Y M-19$
$(267.9)$
$Y M-22$
$(258.5)$

Devitrified modera-

tely welded vitric

tuff with vapor

phase crystalliza-

tion (2.25)

Devitrified moderately welded vitric tuff with minor

vapor phase crys-

tallization. $(2.30)$

(2.30)

Devitrified moderately welded vitric tuff with vapor phase crystallization. (ND)

Devitrified densely welded vitric tuff with vapor phase crystallization. (ND)

Devitrified densely welded vitric tuff with vapor phase crystallization. (2.27)

Devitrified densely welded vitric tuff with minor vapor phase crystallization. (ND)

Devitrified densely welded vitric tuff with vapor phase crystallization. (2.28)

Devitrified densely welded vitric tuff with vapor phase crystallization. (2.31) ibrous/granular $<8 u m$ dianm (matrix)

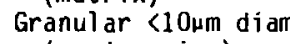

(pumice rims)

Subanhedral 60-200um diam

(pumice core)

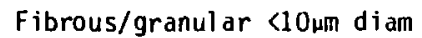
(matrix)

Fibrous 3-5 $\mu \mathrm{m}$ wide $\times 70-100 \mu \mathrm{m}$ long (shards)

Granular 2-10um diam

Spherul itic

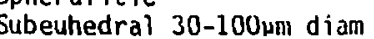

Fibrous (3นm diam (shards)

Equigranular $33 \mu \mathrm{m}$ diam

$$
\text { (matrix) }
$$

Spherul ites <8um diam

(pumice)

Tabular euhedral 20-100 $\mathrm{mm}$ long (pumice)

Fibrous/granular ( $3-10 \mu m$ diam (matrix,pumice $r i m s$ )

Spherulites (pumice)

Euhedral tabular <100um diam (vugs)

Fibrous/granular $<3 \mu m$ diam (matrix)

Granular <10um diam

(pumice rim)

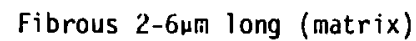
Spherulitic patches 300-600 um diam

Tabular euhedral $<70 \mu m$ long (vugs)

Granular (5um diam (matrix)

Fibrous $<5 \mu \mathrm{m}$ wide $\times<30 \mu \mathrm{m}$

long (vug rims)

Sub/euhedral blocky $<100 \mu m$ diam (vug fill)

Granular 5-15um diam (matrix) Spherul ites $1-2 \mathrm{~cm}$ diant Blocky <300pm dian (pumice)
Mix $30 \% \mathrm{Cr}+70 \% \mathrm{KAF}$

$\mathrm{Cr}, \mathrm{KAF}$

Mix 15-50\% $\mathrm{Cr}+$

$65-50 \%$ KAF, HaAF

Cr, MAF

Mix 30\% $\mathrm{Cr}+70 \% \mathrm{KAF}$

$\operatorname{Mix} 40 \% \mathrm{Cr}+60 \% \mathrm{KAF}$

$\mathrm{Cr}, \mathrm{KAF}$

\section{Mix $40 \% \mathrm{Cr}, \mathrm{Q}+60 \%$ \\ KAF to $20 \% \mathrm{Cr}, 0$ \\ $+80 \%$ KAF}

Mix 50\% Cr, Q + 50\% KAF

$\mathrm{Mix} 10 \% \mathrm{Cr}, \mathrm{Q}+90 \% \mathrm{KAF}$

$\operatorname{Cr}(Q), \mathrm{KAF}$

Mix 30\% Q + 70\% KAf

$Q(C r), K A F$

$\operatorname{Mix} 40 \% \mathrm{Q}, \mathrm{Cr}+60 \% \mathrm{KAF}$

$Q(C r)$, KAF

$\operatorname{Mix} 40 \% \mathrm{Q}, \mathrm{Cr}+60 \% \mathrm{KAF}$ $\mathrm{Mix} 20 \% \mathrm{Q}, \mathrm{Cr}+80 \% \mathrm{KAF}$ $Q(C r), K A F$
En echelon fractures parallel to fabric are filled with quartz

En eclieion fractures parallel to fabric are filled with quartz

En ecielon fractures parallel to fabric are filled with quart $z$

Fractures are filled with quartz

Lithic rich (with cherts)

Fractures are filled with

quartz 
Devitrified densely welded vitric tuff with vapor phase

Granular 5-15ull diam (matrix Spherul ites $1-2 \mathrm{~cm}$ diam Blocky $<300 \mu m$ diam (pumice)

$\operatorname{Mix} 35 \% \mathrm{Q}, \mathrm{Cr}+65 \% \mathrm{KAF}$ crystallization.

(2.35)

YM-26

$(323.3$

YM-27

$(339.1)$

YM-28

(351.3)

YM-29

(364.3)

$Y M-30$

(385.4)

$Y M-31$
$(389.9)$

$Y M-32$

(403.5)

$Y M-33$

(409.1)
Devitrified densely welded vitric tuff with vapor phase crystallization.

(2.34)

Devitrified densely welded vitric tuff with vapor phase crystallization.

(2.32)

Devitrified densely welded vitric tuff with vapor phase crystallization.

(2.30)

Granular 5-15um diam (matrix) Spherulites $1-2 \mathrm{~cm}$ diam Bl ocky $<300 \mu m$ diam (pumice)

$\operatorname{Mix} 30 \% Q+70 \%$ KAF

Mix $20 \% Q+80 \%$ KAF

$Q(C r), K A F$

Granular 5-15um dian (matrix) Spherulites $1-2 \mathrm{~cm}$ diam

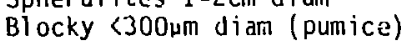

$\operatorname{Mix} 30 \% \mathrm{Cr}, \mathrm{Q}+65 \% \mathrm{~K}$, $\mathrm{NaAF}$

$\operatorname{Cr}(Q), K A F, A b$

Granular 5-20um diam (riatrix)

Spherul ies $1-2 \mathrm{~cm}$ diam

Mix $40 \% Q(C r)+55 \%$

NaAF

$Q(C r)$, KAF, NaAF

Devitrified densely

vitric tuff with

Fibrous/granular 5-15um diam (matrix) $\begin{array}{ll}\text { vapor phase crystal - Spherulitic patches (4um diam } \\ \text { lization.(2.32) } & \text { Tabular }<250 \mu m \text { long (pumice) }\end{array}$

Devitrified densely Fibrous orange/brown to

welded vitric-lithic colorless (shards)

tuff (vitrophyre) Spherulitic $<150 \mu m$ dian

with minor vapor Equant 2-200pm diam (pumice)

phase crystalliza- Fracture filling

tion. $(2.12,+$ cracks $)$

Densely welded

vitric tuff

(vitrophyre).

(2.22)

Hydrated (?) glass

'High' birefringent phase

<lum diam lining/filling

perlitic cracks

Altered nonwelded Colorless <lum diam (shards)

vitric-lithic tuff. Sub/euhedral tabular $\$ 60 \mathrm{~mm}$

(1.64)

long (vug lining)

Al tered nonwelded vitric lithic tuff (ND)
Colorless <lum diam (sllurds) Sub/euhedral tabular <60 m long (vug lining)
$\operatorname{Mix} 35 \% \mathrm{Q}(\mathrm{Cr})+65 \% \mathrm{KAF}$

Mix 60\% Q(Cr) $+40 \% \mathrm{KAF}$

Q, KAF

Mix 10-40\% $Q(C r)+90-60 \%$ Irregular branching KAF

Cr, kAF (heul)

Heul

(mont

NA

Heul

Clin

Clin

Sample dominated

by one very

large lithic

frayment
Irregular branching fractures are filled with

Lithic rich fractures ar filles with montmorillonite Lithic rich

n echel on fractures are filled with

quartz

n echelon fractures parallel to fabric are filled with 
Al tered non-to

slightly welded

vitric tuff $(1.65)$

$Y M-35$

(421.4)

YM-36 Bedded Tuffs of (422.0) Calico Hills

YM-37

(446.7)

YM-38

(458.7)

YM-39

$(482.9)$

$\mathrm{YM}-40$

(508.1)

$Y M-41$

(540.8)

Ai tered nonwelded vitric tuff(1.78)

Al tered nonwelded vitric tuff(1.73)

Altered slightly welded vitric tuff (1.75)

Al tered nonwelded vitric tuff(1.83)

Al tered nonwelded vitric tuff(1.81)

Al tered nonwelded vitric tuff(1.61)

Devitrified(?) nonwelded vitric
Pale brown $<1 \mu \mathrm{m}$ dian icement, $\mathrm{Cl}$ in

shards) (mont)

Lithic rich

(siltstones and welded (uff)

Colorless <lum diam (pumice)

clin

(vug lining)

Pale brown <luin diam (cement, shards)

Colorless <1um diam (punice)

Euhedral tabular <10uin lony (vug lining)

Crystalline $(1) \mathrm{m}$ diam (perlite, pumice)

Tabular <60um long (vug lining)

Orange-brown $<1 \mu \mathrm{m}$ fracture filling

Crystalline $<1 u m$ diam (pumice)

in

Clin, (Mont)

(Mont)

Lithic rich wedge-shaped (vug lining) (pumice) Euhedral tabular <80um (vug lining)

Fibrous <lum yellow brown (cement)

Granular <6um (perlite, punice)

Euhedral tabular <30um (vug lining)

Clin

Clin

(perlite) tuff with vapor crystallization (1.54)
Pale brown <6um diam (matrix, $\mathrm{Cl}$ in pumice)

Euhedral tabular $<25 \mu m$ long KAF, Q (vugs)

Pale brown $<4 \mu m$ diam (matrix, Clin pumice)

Lithic rich

\section{undant oxid fracture} filling ithic and crystal rich
Q, KAF 


\begin{tabular}{|c|c|c|c|c|c|}
\hline $\begin{array}{l}Y M-42 \\
(556.1)\end{array}$ & $"$ & $\begin{array}{l}\text { Coarse sandstone: } \\
\text { very inthature } \\
\text { feldspathic vol- } \\
\text { canic litharenite } \\
(2.26)\end{array}$ & NA & NA & $\begin{array}{l}\text { Some zeolitized } \\
\text { (heul) lithics }\end{array}$ \\
\hline $\begin{array}{l}Y M-43 \\
(564.5)\end{array}$ & $\begin{array}{l}\text { Prow Pass Member } \\
\text { of the Crater } \\
\text { Flat Tuff }\end{array}$ & $\begin{array}{l}\text { Devitrified welded } \\
\text { vitric-crystal tuff } \\
\text { with minor vapor } \\
\text { crystallization } \\
(1.74)\end{array}$ & 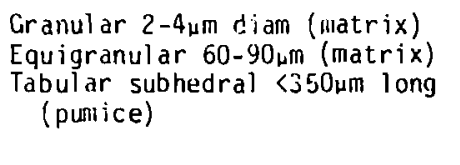 & $\begin{array}{l}\text { Mix } 80 \% Q+20 \% \text { KAF } \\
Q, \text { KAF }\end{array}$ & Crystal rich \\
\hline $\begin{array}{l}Y M-44 \\
(569.7)\end{array}$ & $"$ & $\begin{array}{l}\text { Devitrified welded } \\
\text { vitric-crystal tuff } \\
\text { with minor vapor } \\
\text { crystallization } \\
(1.91)\end{array}$ & 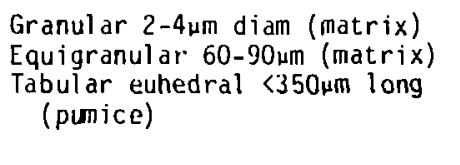 & $\begin{array}{l}\text { Mix } 80 \% Q+20 \% \text { KAF, Ab } \\
\text { Q, KAF }\end{array}$ & Crystal rich \\
\hline $\begin{array}{l}Y M-45 \\
(588.4)\end{array}$ & " & $\begin{array}{l}\text { Devitrified welded } \\
\text { vitric-crystal tuff } \\
\text { with minor vapor } \\
\text { phase crystalliza- } \\
\text { tion(588.4) }\end{array}$ & 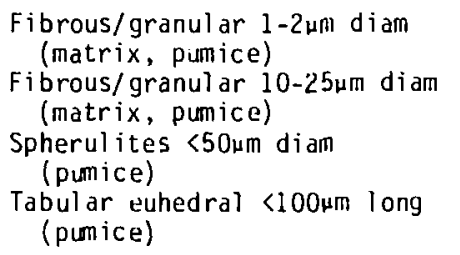 & $\begin{array}{l}\mathrm{KAF}+\mathrm{clay}(?) \\
Q, \mathrm{Ab} \\
Q, \mathrm{KAF}\end{array}$ & Crystal rich \\
\hline $\begin{array}{l}\text { YM-46 } \\
(610.1)\end{array}$ & $"$ & $\begin{array}{l}\text { Devitrified densely } \\
\text { welded vitric- } \\
\text { crystal tuff(2.22) }\end{array}$ & $\begin{array}{l}\text { Anhedral } 6 \mu m \text { wide } \times 60 \mu m \text { long } \\
\text { (shards) } \\
\text { Spherulites } 1.5 \mathrm{~mm} \text { diam } \\
\text { (pumice) } \\
\text { Hematite } 1-3 \mu \mathrm{m} \text { dian }\end{array}$ & $\begin{array}{l}\text { Mix } 60 \% Q+40 \% k \\
\text { NaAF } \\
\text { KAF }\end{array}$ & Crystal rich \\
\hline \multirow[t]{2}{*}{$\begin{array}{l}Y M-47 \\
(636.3) \\
(1.81)\end{array}$} & $"$ & $\begin{array}{l}\text { Altered nonwelded } \\
\text { vitric-crystal tuff }\end{array}$ & $\begin{array}{l}\text { Hydrated glass(?)(shard } \\
\text { interiors) } \\
\text { Fibrolis } 3-5 \mu m \text { long (shard } \\
\text { rims) }\end{array}$ & $\begin{array}{l}\mathrm{NA} \\
\mathrm{Cl} \text { in }\end{array}$ & Crystal rich \\
\hline & & & $\begin{array}{l}\text { Crystalline }<8 \mu m \text { diam (cement) } \\
\text { Crystalline }<3 \mu m \text { diam } \\
\text { (fracture fill) }\end{array}$ & Cl in & $\begin{array}{l}\text { Fractures are filled } \\
\text { with a zeolite }\end{array}$ \\
\hline $\begin{array}{l}\text { YM-49 } \\
(676.8)\end{array}$ & $"$ & $\begin{array}{l}\text { Altered nonwelded } \\
\text { vitric tuff(1.92) }\end{array}$ & $\begin{array}{l}\text { Fibrous } 10-15 u m \text { long } \\
\text { (pyroclasts) } \\
\text { Euhedral tabular } 15-25 \mu m \text { long } \\
\text { (vug lining) }\end{array}$ & $\mathrm{Clin} \pm$ Mord & Crystal rich \\
\hline $\begin{array}{l}Y M-50 \\
(702.4)\end{array}$ & " & $\begin{array}{l}\text { Altered nonwel ded } \\
\text { vitric-crystal tuff } \\
(1.97)\end{array}$ & $\begin{array}{l}\text { Fibrous } 10-20 \mu m \text { long } \\
\text { (pyroclasts) } \\
\text { Euhedral tabular } 15-25 \mu \mathrm{m} \\
\text { long (vug lining) }\end{array}$ & $\mathrm{Clin} \pm$ Mord $+Q$ & Crystal rich \\
\hline
\end{tabular}




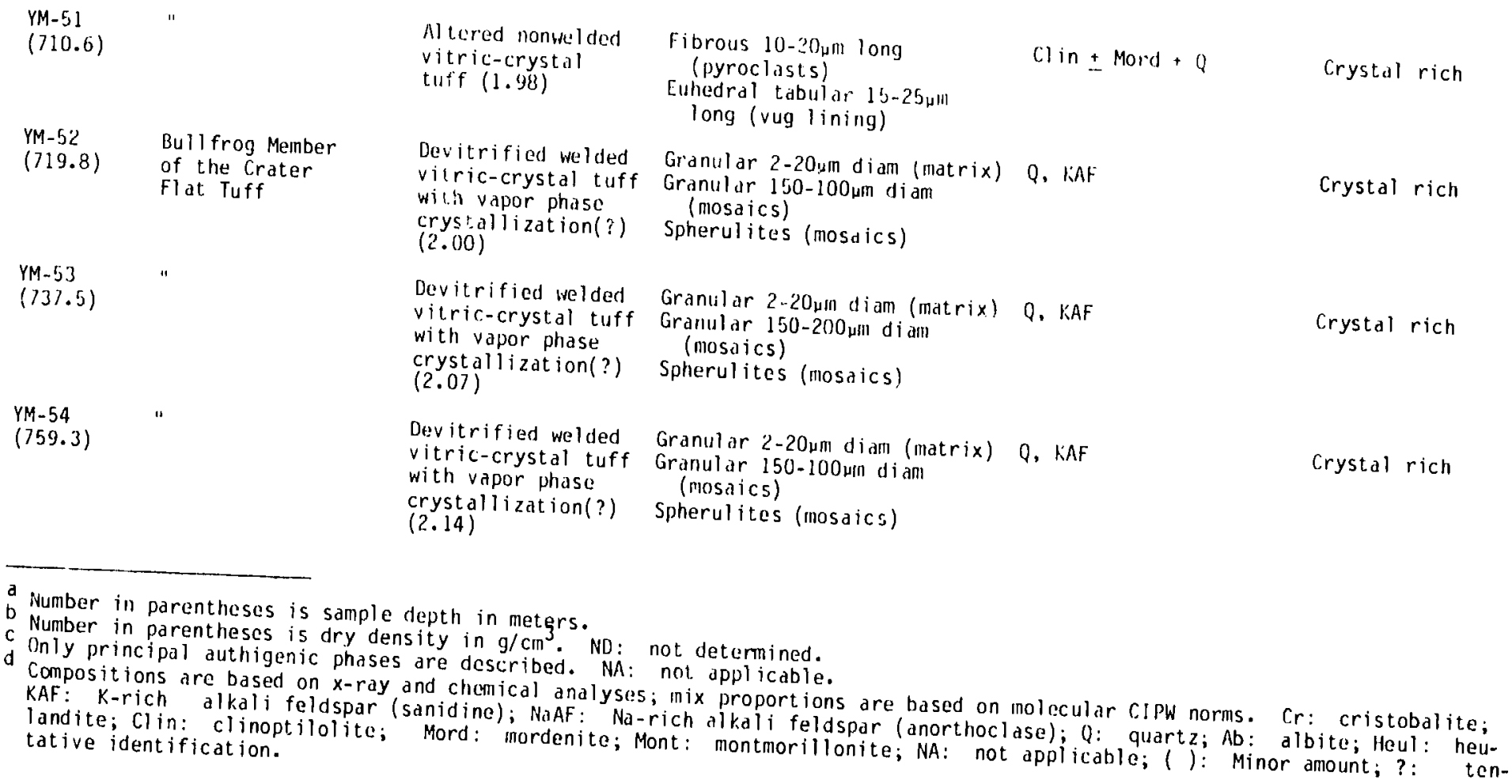




\begin{tabular}{|c|l|c|}
\hline Clast size & Clast name & $\begin{array}{c}\text { Rock riame } \\
\text { (if majority of clasts } \\
\text { in the' size range) }\end{array}$ \\
\hline$>256$ & Coarse blocks & Pyroclastic breccia \\
\hline $64-256 \mathrm{~mm}$ & Fine blocks & \\
\hline $2-64 \mathrm{~mm}$ & Lapilli & Lapillistone \\
\hline $1 / 16-2 \mathrm{~mm}$ & Coarse ash & \\
\hline$<1 / 16 \mathrm{~mm}$ & $\begin{array}{c}\text { Dust (or } \\
\text { fine ash) }\end{array}$ & Tuff \\
\hline
\end{tabular}

Fig. 2

Fisher's (1961) grain-size classification for volcaniclastic rocks.

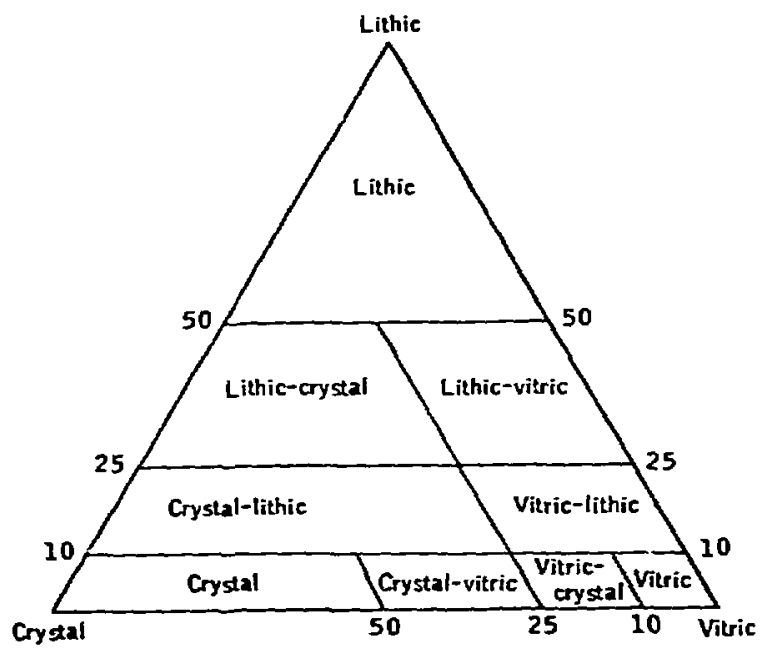

Fig. 3

Cook's (1965) classification of volcaniclastic rocks.

use the terms 'nonwelded,' 'moderately welded,' 'densely welded,' etc., to describe the observed degree of shard/pumice compaction or deformation. The term 'welded' is used in cases where texture has been almost completely obliterated by alteration, but some fabric is still observable.

Alteration of vitric pyroclasts in tuff can occur by: (1) devitrification of the hot pyroclistic flows; (2) vapor phase crystallization by release of hot volatiles during cooling of pyroclastic flows; and (3) interaction of ground water with tuffs. To date, it is possible only to qualitatively, rather than quantitatively, distinguish these processes. We therefore refer to the products of these various modes of alteration as 'authigenic phases' without genetic connotation. Where process identification is made, criteria are those described in Ross and Smith (1961) for devitrification and vapor phase crystallization. Secondary mineralization refers to ground water/rock interactions, and includes zeolitization, silicification, and calcitization. 


\section{STRATIGRAPHY}

\section{A. Crater Flat Tuff}

1. Bullfrog Member. This is the oldest unit encountered in drill hole UE25a-1; only the upper $51 \mathrm{~m}$ was penetrated. The three samples obtained from the Bullfrog are very similar: all are densely welded (relict textures are poorly preserved), crystal-rich (about $20 \%$ sanidine, oligoclase, quartz, biotite, and magnetite), and very poor in lithics. Dccasional xenocrysts of mafic phases now altered to phlogopite plus hematite al so occur.

The primary mode of alteration in the Bullfrog Member is coarse (granophyric) devitrification, with possibly some vapor phase crystallization or silicification. No zeolite minerals were observed.

2. Prow Pass Member. The upper member of the crater Flat Tuff encountered in UE25a-1 is about 152-m thick, compared to exposures that are 15.2-m thick at the type locality in Prow Pass or 50-m thick at Crater Flat (Byers et al., 1976). In this section the upper $60 \mathrm{~m}$ of the Prow Pass is a crystal-rich $(10-14 \%)$ densely to partially welded pyroclastic flow deposit. The lower portion is slightly less crystal-rich $(5-8 \%)$ and nonwelded.

The abundant phenocrysts consist predominantly of sanidine, resorbed quartz, and albite or oligoclase, with occasional anorthoclase, biotite, pyroxene, and magnetite. Lithic concentration is variable, ranging from less than 1 to $5 \%$; clasts are of altered welded tuffs and/or siltstone.

The more densely welded upper zone of the Prow Pass Member is devitrified to medium- to fine-grained granular or occasionally fibrous/spherul itic phases; the grain size of devitrification products is less coarse than in the Bullfrog Member. Vapor phase crystallization occurs as crystalline vug (relict pumice clast) linings or fillings. The nonwelded portion of the Prow Pass Member is completely zeolitized: clinoptilolite with rare mordenite replace both matrix material and pyroclasts. Minor silicification and/or vapor phase crystaliization occur at depths of 702 and $711 \mathrm{~m}$.

B. Bedded Tuff of Calico Hills

This unit is an approximately $144 \mathrm{~m}$ thick sequence of bedded tuff, air fall tuff, pyroclastic flows, and volcaniclastic sedimerts. All but the lowermost sample encountered in this section, a sandstone, appear to be nonwelded tuff. Nonvesicular perlitic clasts comprise the bulk of samples $\mathrm{M}-36,-38$, 12 
and -39 (422.0-, 458.7-, and 482.9-m depth respectively). The nonwelded tuffs of the Calico Hills are crystal-poor, containing 2 - 4\% ol iogoclase, sanidine, quartz, and occasionally biotite. Lithic clasts of altered welded tuffs and rhyolitic (?) lavas comprise only 2 - $4 \%$ of samples with the exceptions of YM-38 and -39 which contain about $8 \%$ lithics.

The basal sandstone is a very immature feldspathic litharenite with a matrix of Fe-stained clay. Clasts are predominantly lithic fragments (devitrified or zeolitized welded tuff, perlite, and lava) and crystals (andesine, biotite, and magnetite). Calcite orcurs both as a fracture filling and as pseudomorphs after plagioclase.

The upper $500 \mathrm{~m}$ of these bedded tuffs is completely zeulitized as in the nonwelded portion of the Prow Pass Member of the Crater Flat Tuff. Below 500 $m$ depth, zeolitization is accompanied by minor silicification of the matrix, and $K$-feldspar and quartz occur as vug and vesicle linings or fillings.

C. Paintbrush Tuff

1. Topopah Springs Member. The lower unit of the Paintbrush Tuff is about 333-m thick in drill hole UE25a-1, compared to a maximum reported thickness of about $275 \mathrm{~m}$ at the west $\mathrm{flank}$ of the CP Hills (Byers et al., 1976). Variation in degree of welding through the unit is typical of thick, compound cooling units (Lipman et al., 1966); the basal zone is nonwelded, grading up into a vitrophyric zone of dense welding that is overlain by thick sequences of devitrified densely to moderately welded tuff.

An upper densely welded zone corresponds to the quartz-latite caprock described by Lipman et al. (1966). Crystals of sanidine, oligoclase, anorthoclase, pyroxene, biotite, and magnetite comprise up to $17 \%$ of the samples. The moderately-welded zone and vitrophyre contain less than $3 \%$ phenocrysts; sanidine, plagioclase, anorthoclase, biotite, and magnetite are present. The nonwelded base is al so crystal-poor, containing 1 to $4 \%$ alkali feldspar, ol igoclase, magne:ite, quartz, and occasional biotite.

Lithic fragments are scarce (less than $3 \%$ by volume) in the Topopah Springs Member above the nonwelded base, and consist of welded tuff and rhyolitic lava clasts; chert clasts were found in sample YM-24 (about 286-m depth). Sample YM-30 (385-m depth) contains about $9 \%$ clasts of welded tuff and occasional perlitic glass. 
Alteration modes vary through the Topopah Springs Member. The uppermost densely welded sample and the basal vitrophyre are unaltered and have glass of dacitic to rhyolitic composition respectively. The remainder of the densely to moderately welded zone is extensively devitrified to fine-grained fibrous/spherulitic or granular phases. Vapor phase crystallization is welldeveloped in this section, predominantly as zoned vug (relict pumice clast) fillings. Lithophysae are represented in thin section by spherical to ovoid, coarsely crystalline mosaics in the matrix and occasionally in relict pumice clasts.

The shallowest drill hole occurrence of zeolites in UE25a-1 core samples is as fracture filling and minor vug linings in the basal vitrophyre of the Topopah Springs Member at about 385-m depth. Below the vitrophyre, zeolitization is extensive, completely replacing all pyroclasts and matrix with clinoptilolite.

2. Tiva Canyon Member. Only $64 \mathrm{~m}$ of this upper unit of the Paintbrush Tuff is exposed in UE25a-1 compared to observed thicknesses of $107 \mathrm{~m}$ at the type section in Tiva Canyon and to about $200 \mathrm{~m}$ near Beatty (Byers et al., 1976). Only the lowermost crystal-poor sanidine- and hornblende-bearing high silica portion (Byers et al., 1976) of this pyroclastic flow is present; the upper part has been removed by erosion, and the unit is covered by about $9 \mathrm{~m}$ of alluvium.

The cored section of the Tiva Canyon member at UE251-1 has a densely welded upper zone, extending to about $60-\mathrm{m}$ depth, and a nonwelded base from 60-70-m depth. A layer of 'bedded tuff' about 9-m thick beneath the nonwelded zone is included in the Tiva Canyon Member.

The densely welded upper zone is very poor in phenocrysts, containing less than 5\% sanidine, magnetite, plagioclase, hornblende, and sphene. The nonwelded base is crystal-rich, containing about $14 \%$ oligoclase, sanidine, biotite, magnetite, and orthopyroxene. The bedded tuff is slightly less crystal-rich than the nonwelded base, containing about $11 \%$ andesine/oligoclase, sanidine, biotite, magnetite, and orthopyroxene. Lithic fragments, usually consisting of clasts of altered welded tuffs, are rare in the Tiva Canyon Member; they are virtually absent in the densely-welded zone and comprise only about $2 \%$ of the nonwelded base and bedded tuff. Clasts of an immature sandstone are found in the bedded tuff. 
Alteration in the Tiva Canyon is restricted to the upper, welded zone and consists primarily of sub- m fibrous/spherulitic or granular devitrification products. Vapor phase crystallization occurs most often as crystalline rims or fillings of lenticular vugs (relict pumice clasts). The nonwelded base and bedded tuff are virtually unaltered; pyroclast rims may be partly hydrated, and are slightly ragged in the bedded tuff. Glass analyses give rhyolitic to dacitic compositions for the nonwelded base and bedded tuff respectively.

\section{v. FRACTURES}

Fracture density and morphology of samples from UE25a-1 are determined from thin sectioned samples and therefore may not be totally representative of in situ fractures. Fractures are defined as open or filled cracks of some linear extent, usually greater thalı $0.5 \mathrm{~mm}$ long. Perlitic cracks and fractures in phenocrysts are not included.

There is a general decrease in fracture density with depth in the drill section. The Tiva Canyon Member of the Paintbrush Tuff has a low fracture density; only a few open and rare filled frastures occur in the nonwelded zone. In contrast, the Topopah Springs Member has abundant filled fractures throughout most of the moderately to densely welded zone (samples YM-18 through -30 , about $250-385-m$ depth), as reported by Spengler et al. (1979). The bedded tuffs of Calico Hills have very few fractures. The Prow Pass Member of the Crater Flat Tuff has no fractures in the densely welded zone, and a moderate amount in the nonwelded zone (YM-48 through -50, about 640 700-m depth). No fractures were observed in the Bullfrog Member.

In the highly fractured Topopah Springs Member, fractures are usually en echelon and parallel or subparallel to relict fabric (Fig. 4). In the basal vitrophyre irregular branching fractures predominate (Fig. 5). A few older, healed fractures nomal to relict fabric were also observed. Fractures average $5-20 \mu \mathrm{m}$ in width, with a maximum of about $150 \mu \mathrm{m}$.

Fractures are most often filled with coarse, polycrystalline quartz (Fig. 4), but occasionally are filled or lined with montmorillonite and/or zeolite (Fig. 6). Alteration zones of fine-grained clear quartz occur parallel to some of the wider fractures occur as bands up to $0.6 \mathrm{~mm}$ wide.

In the Prow Pass Member of the Crater Flat Tuff both branching, normal fractures and en echelon parallel fractures are observed. These are smaller 


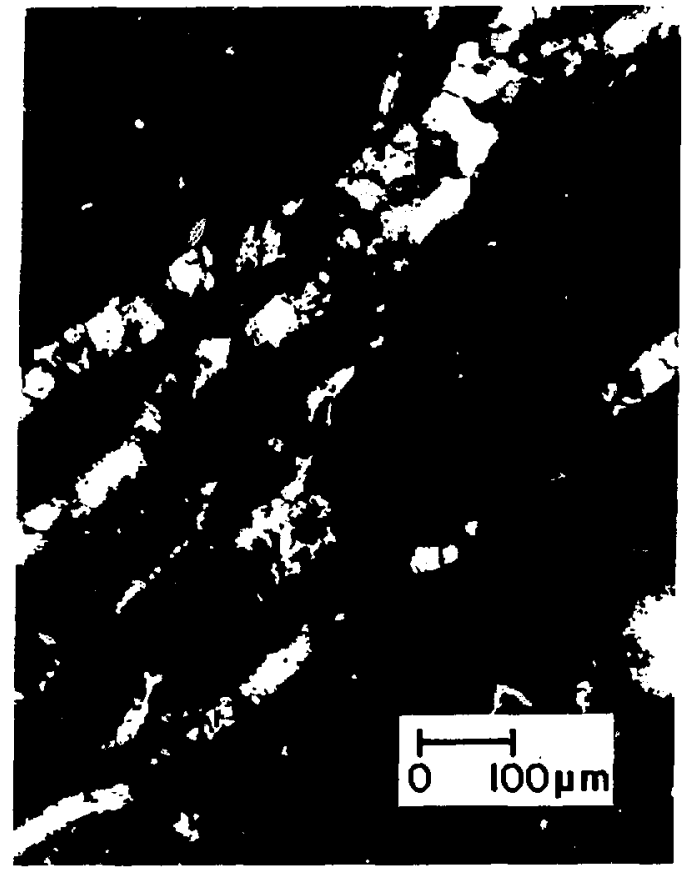

Fig. 4

En echelon fractures filled with quartz parallel to relict fabric

Photomicrograph of YM-29 (Topopah Springs Member of Paintbrush Tuff; with crossed nicols.

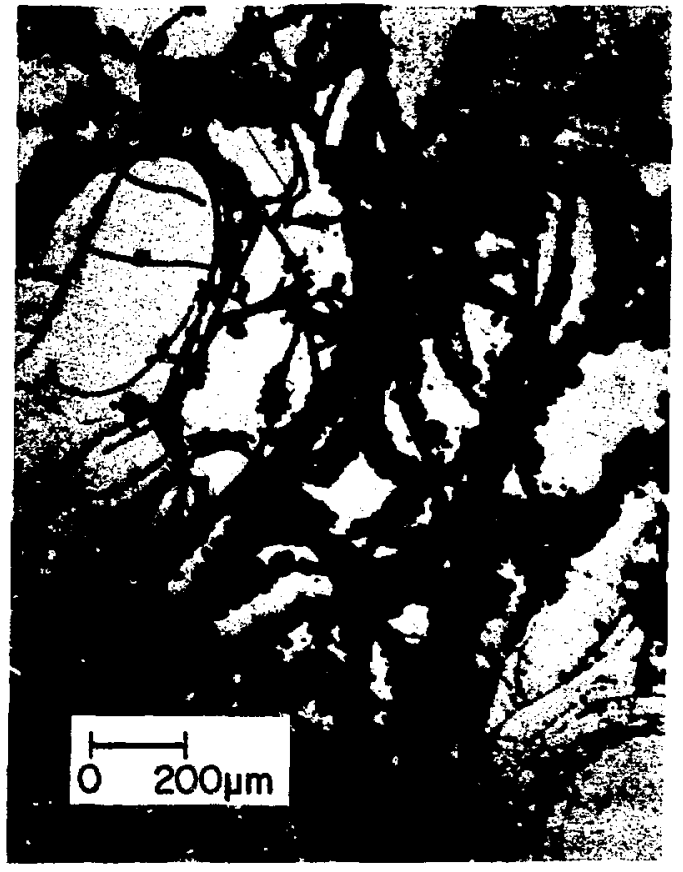

Fig. 5

Fractures and perlitic cracks normal to relict fabric filled with montmorillonite. Reflected light photomicrograph of YM-31 (Topopah Springs Member of Paintbrush Tuff).

than those of the Topopah Springs Member, averaging $5-10 \mu \mathrm{m}$ in width with a maximum of about $40 \mathrm{\mu m}$. Most fractures of the Prow Pass Member are either open or 1 ined with a very fine-grained phase (montmorillonite?).

With the exception of those in the Topopah Springs, fractures crosscut al1 primary and secondary tuff features. In the Topopah Springs Member, the en echelon filled fractures cross cut lithic fragments, phenocrysts, and matrix but in turn are crosscut by zones of coarse authigenic crystallization (Fig. 7). In some instances fracture fillings appear to be recrystallized within the authigenic. These relationships imply that some of the textures attributed to devitrification and vapor phase crystaliization in the Topopah Springs probably developed following deposition, fracturing, and fracturefilling. 


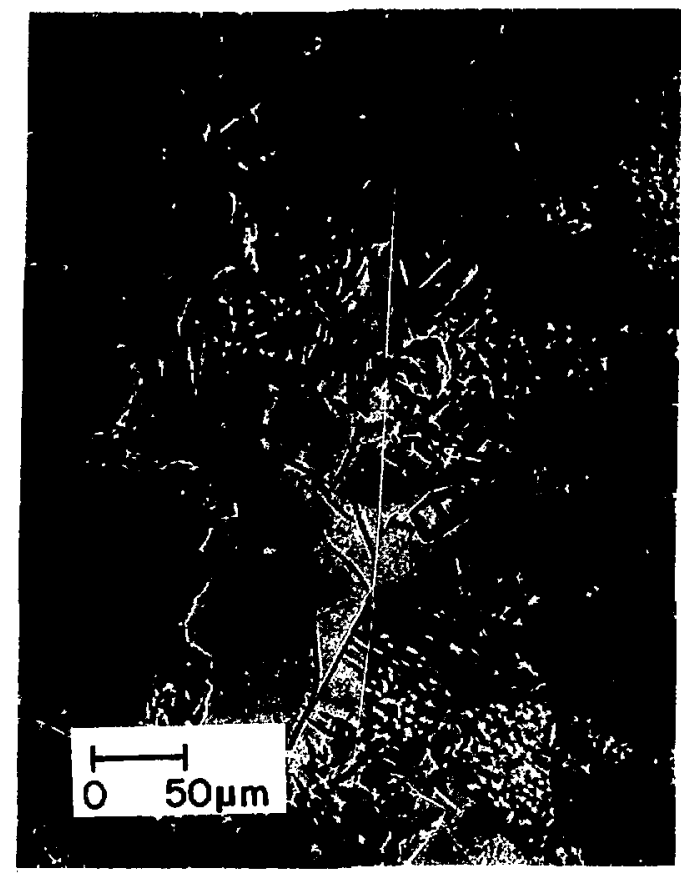

Fig. 6

Heulandite crystals present as fracture lining. Transmitted light photomicrograph of YM-30 (Topopah Springs Member of Paintbrush Tuff).

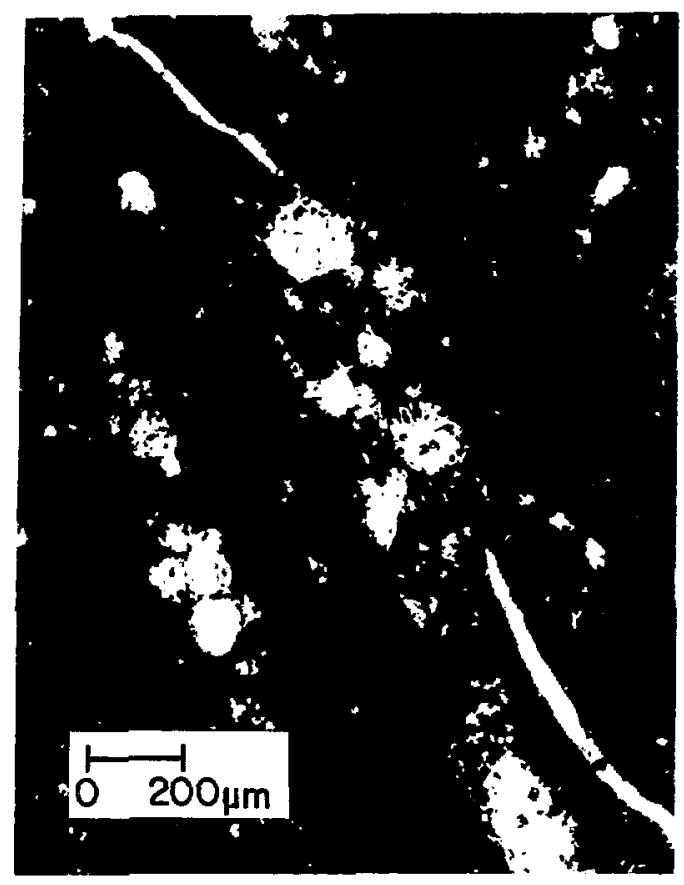

Fig. 7

Filled fracture overgrown by coarse authigenic phases. Photomicrograph with crossed nicols of YM-27 (Topopah Springs Member of Paintbrush Tuff).

VI. AUTHIGENIC PHASES

Devitrification, vapor phase crystallization, and zeolitization are the major modes of alteration in samples from UE25a-1. As noted previously, it is often difficult to distinguish the processes which produce the observed authigenic phases, particularly in highly altered samples. The foliuwing descriptions of the occurrence, texture, and composition of authigenic phases in the Yucca Mountain samples are intended only to give a general picture; detailed descriptions of the phases are given in the Appendix, and are summarized in Table I. 
A. Devitrification

Devitrification occurs in all the welded portions of the Paintbrush and Crater Flat Tuffs, with the exceptions of the basal vitrophyre (YM-31) and uppermost densely welded sample (YM-6) of the Topopah Springs Member. Devitrification products increase in grain size with depth in the drill hole.

Fig. 8A shows the typical fine-grained, fibrous style of devitrification found in the Paintbrush Tuff. The fibrous phases replacing shards are usually less than $3 \mathrm{\mu m}$ wide and grow normal to relict shard boundaries. Shard boundaries are preserved by chains of sub-um plates or dendrites of an opaque reddish-brown phase, probably an Fe-oxide. Spherulites (Fig. 8B) occur most often in relict pumice clasts but occasionally cross relict clast boundaries. Granular phases less than $10 \mathrm{~mm}$ in diameter occur alone or mixed with the fibrous phases.
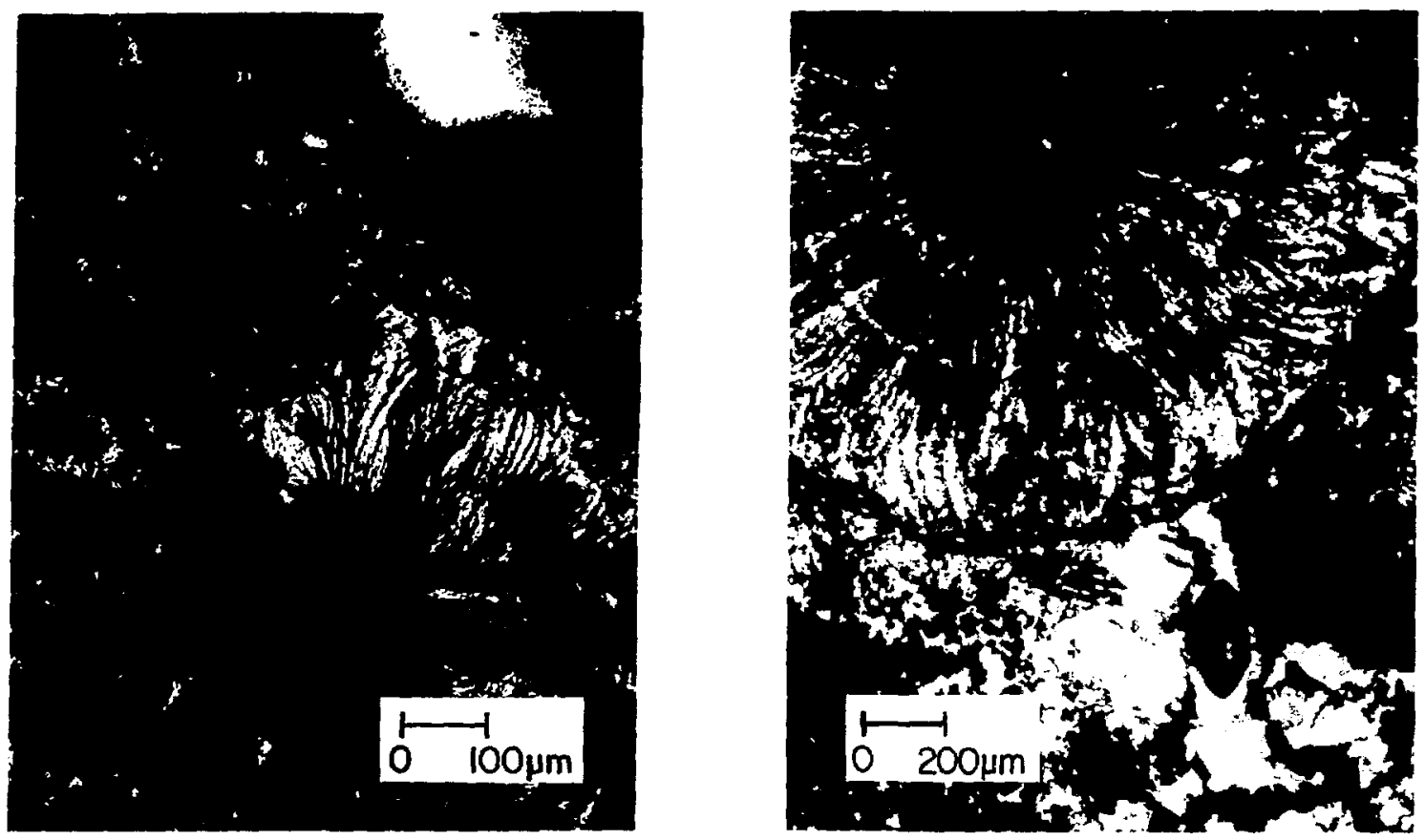

Fig. 8

Devitrification products in YM-2B (Tiva Canyon Member of Paintbrush Tuff). Photomicrographs with crossed nicols.

A. Fine-grained fibrous phases replacing relict shards. Note that fibers grow normal to relict shard boundaries.
B. Spherulite cross-cutting relict pyroclast boundaries. 


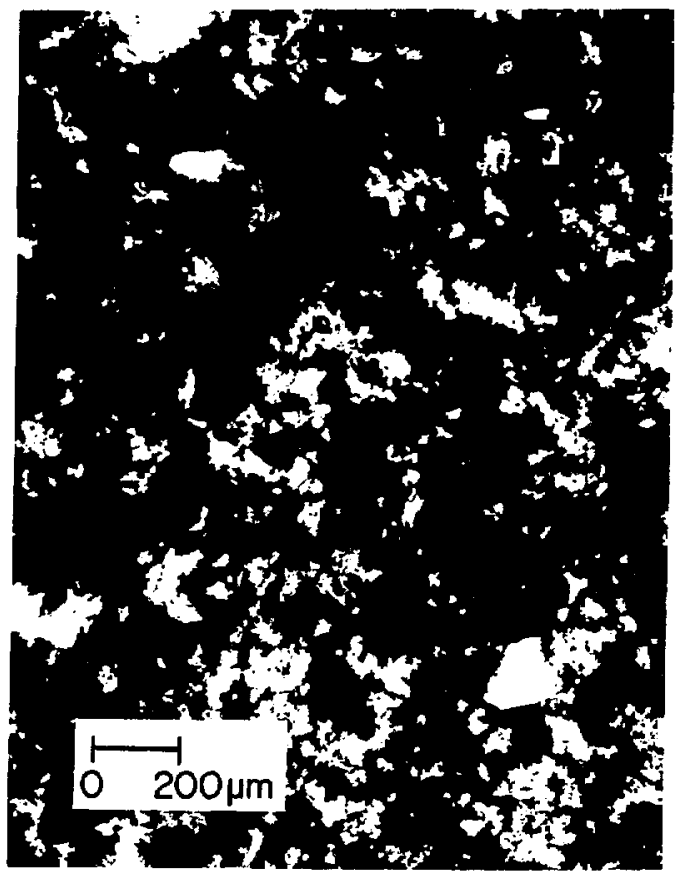

Fig. 9

Coarse, granophyric devitrification. Photomicrograph with crossed nicols of YM-53 (Bullfrog Member of Crater Flat Tuff).

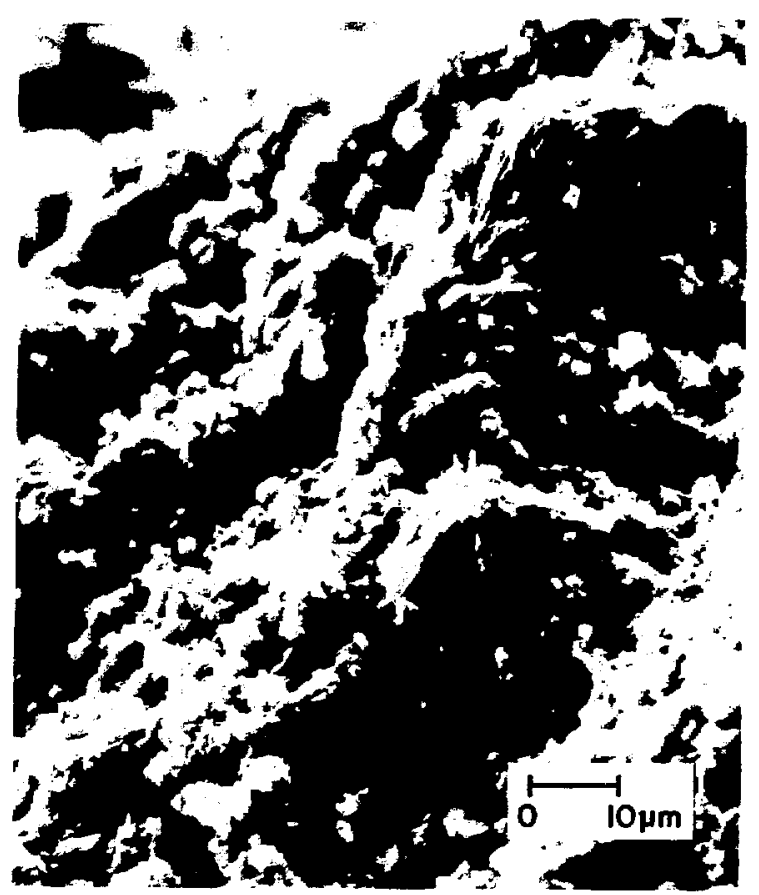

Fig. 10

Fine granular and fibrous devitrification phases (alkali feldspar and quartz). SEM photograph of fracture surface, YM-43 (Prow Pass Member of Crater Flat Tuff).

In the Crater Flat tuff, devitrification is coarse, approaching a granophyric texture which tends to obliterate relict textures (Fig. 9). Finegrained fibrous phases sometimes occur lining voids, and coarsely crystalline spherulites are present in relict pumice clasts (Fig. 10).

Compositionally, devitrification products consist of $\mathrm{SiO}_{2}$ (quartz or cristobalite), K-feldspar, and rare Na-feldspar or a mixture of these.* The finer-grained devitrification products of the Paintbrush and Crater Flat Tuffs average $40 \% \mathrm{SiO}_{2}$, 60\% K-feldspar and $80 \% \mathrm{SiO}_{2}, 20 \% \mathrm{~K}$-feldspar respectively. Spherulites are usually more feldspar-rich than other phases.

*Microprobe analysis of discrete grains was impossible for the finer-sized grains; proportions of $\mathrm{SiO}_{2}, \mathrm{KAlSi}_{3} \mathrm{O}_{8}$, and $\mathrm{NaAlSi}_{3} \mathrm{O}_{8}$ in the resulting mixed analyses were determined from normative compositions. 


\section{B. Vapor Phase Crystallization}

Vapor phase crystallization is developed to varying extents in the welded portions of the Paintbrish and Crater Flat Tuff. In both units it occurs primarily as linings or fillings of lenticular vugs, as shown in Fig. 11 . These linings are coarser than the matrix, averaging $50-300 \mu \mathrm{m}$ in diameter, and us':ally consist of subhedral to euhedral tabular, blocky, or wedge-shaped crystals. Vapor phase crystallization al so occurs as coarse crystals admixed with coarse spherulites and finer, granular phases in roughly-zoned large relict pumice clasts (Fig. 12). Most of these vapor phases are $\mathrm{SiO}_{2}$ (quartz or cristobablite) with lesser amounts of $\mathrm{K}$ - or rarely $\mathrm{Na}$-feldspar.

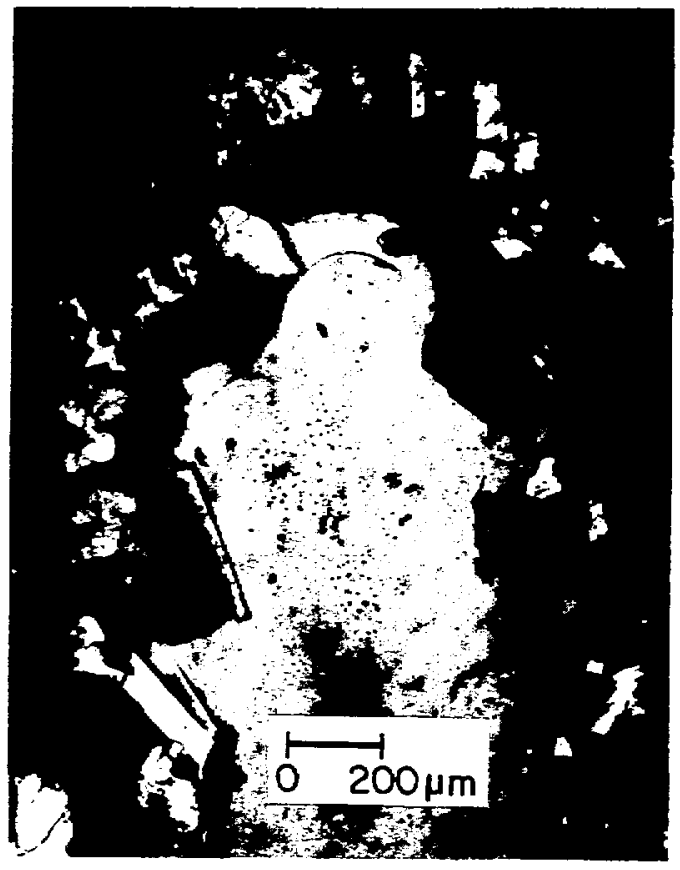

Fig. 11

K-feldspar and cristobalite crystals lining a zoned, lenticular vug. Photomicrograph with crossed nicois of YM-7B (Topopah Springs member of Paintbrush Tuff).

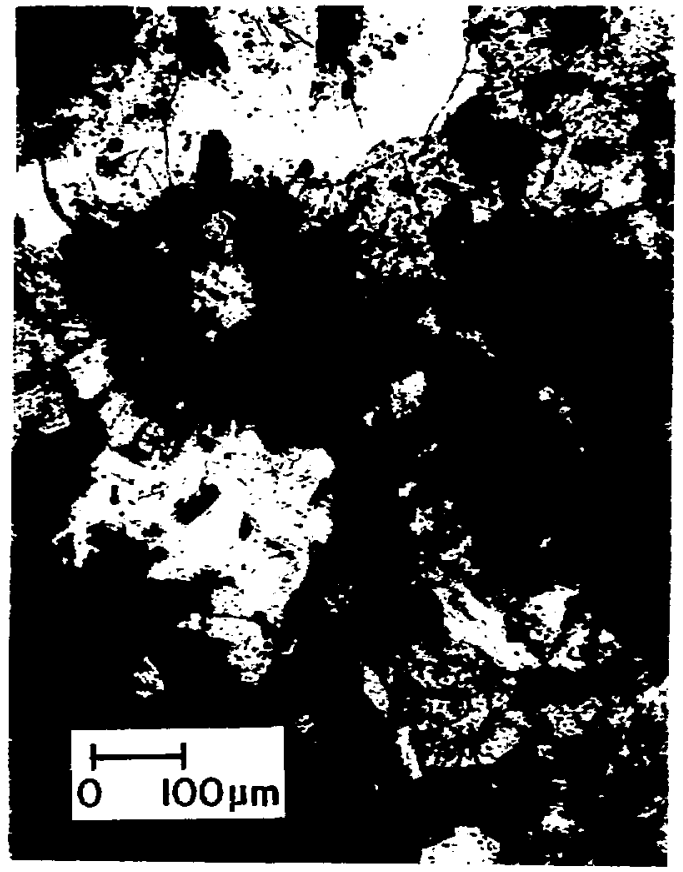

Fig. 12

Interior of irregularily zoned relict pumice clast. Spherul ites and crystals are K-feldspar with minor quartz. Photomicrograph with crossed nicols of YM-24 (Topopain Springs Member, Paintbrush Tuff). 
In the Topopah Springs Member a feature similar to vapor phase crystallization occurs which may be a smal1-scale expression of the abundant lithosphyre found in that member. These are spherical to ovoid mosaics, usually less than $100 \mu \mathrm{m}$ in diameter which consist of $\mathrm{SiO}_{2}$ and subsidiary K-feldspar (Fig. 13). These authigenic patches occur primarily in sample matrices and sometimes in the irregularly-zoned relict pumice clasts. Occasionally they serve as nuclei for spherulites.

\section{Zeolitization}

Two sequences of zeolitization occur in UE25a-1: one from the basal vitrophyre of the Topopah Springs Member to the basal sandstone of the Tuffaceous Beds of CalicO Hills (385.4 540.8-m depth), and the second in the Pass Member (636.3 - b10.6-m depth) Zeolites occur as: (1) fracture fillings or linings (Fig. 6); (2) pseudomorphs of pyroclasts and matrix replacement; and (3) vug linings or fillings (Fig. 14). Grain morphology is varied, including very rine-grained feathery intergrowths (mostly in matrices), sub- $\mu \mathrm{m}$ fibrous or granular phases in relict pyroclasts, and euhedral tabular to prismatic or wedge-shaped crystals in vugs (Fig. 15). In the lower part of each zeolitized sequence, minor amounts of quartz and K-feidspar occur as vug linings or in the matrix.

The principal zeolite encountered in the cores from UE25a-1 is calcic clinoptilolite. This mineral appears to have formed by the action of ground water on the glass shards and ash of the original volcanic material. Minor amounts of heulandite (distinguished by lower Si/Al ratios) were observed as a fracture-filling in the basal vitrophyre of the Topopah Springs Member. Clinoptilolite comprises more than 80 percent of the specimens of the Topopah 

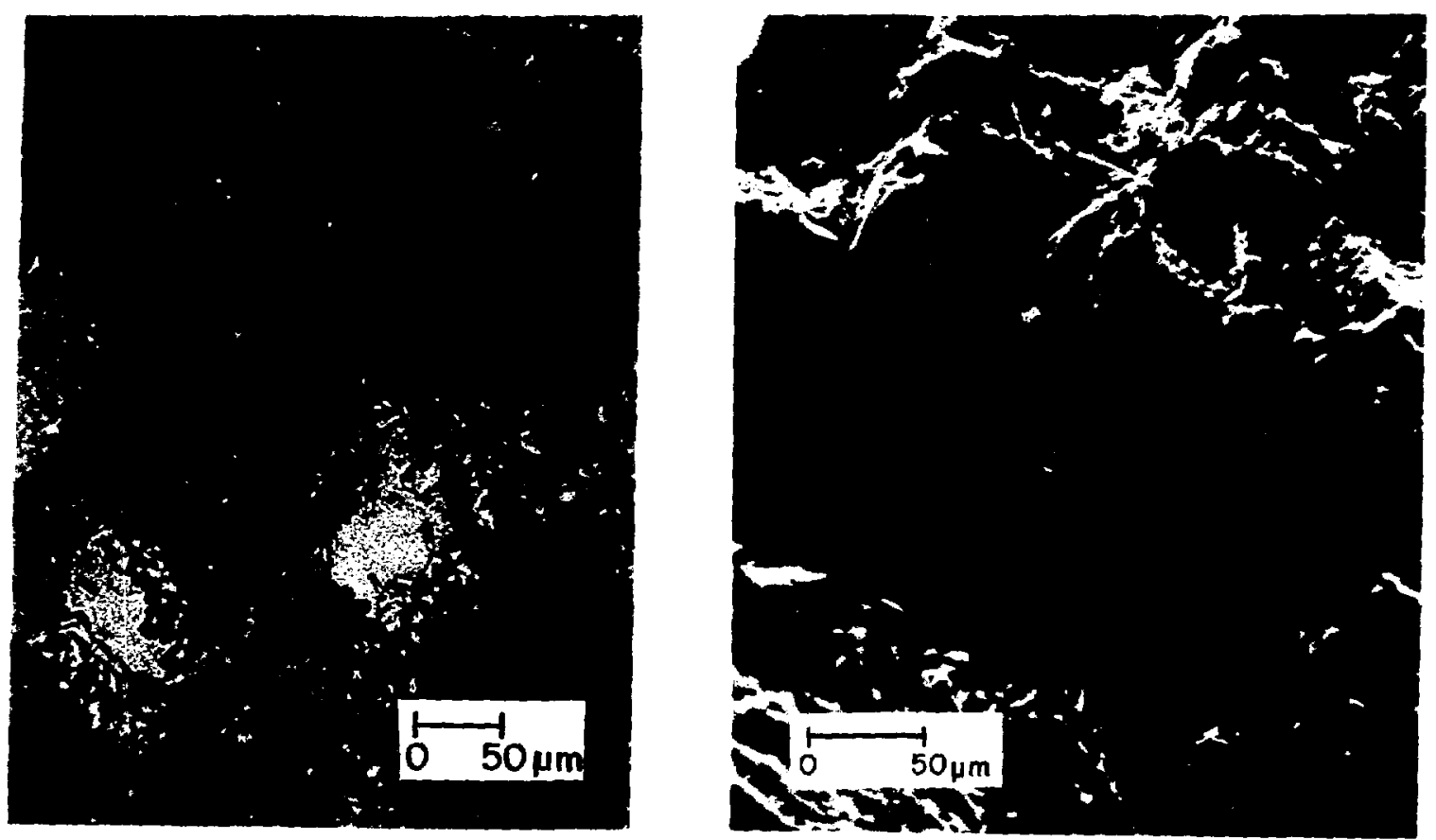

Fig. 14

Clinoptilolite crystals lining vugs in YM-49 (Prow Pass Member of Crater Flat Tuff).

A. Transmitted light photomicrograph of crystals lining voids in relict shards.
D. SEM photograph of fracture surface showing tabular crystals lining a vug.

Springs Member below the basal vitrophyre and of the bedded tuff of Calico Hills (YM-32 through -41; 403.5 - 540.8-m depth inclusive) and including major portions of the nonwelded units of the Crater Flat Tuff.

Clinoptilolite is isostructural with heulandite and the distinction between the two has been the subject of some discussion in the 1 iterature (Mason and Sand, 1960; Mumpton, 1960; Boles, 1972). The latter author concluded that all compositions between clinoptilolite $\left((\mathrm{Na}, \mathrm{K})_{6} \mathrm{Al}_{6} \mathrm{Si}_{30} \mathrm{O}_{72} \cdot 24 \mathrm{H}_{2} \mathrm{O}\right)$ and heulandite $\left(\mathrm{Ca}_{4} \mathrm{Al}_{8} \mathrm{Si}_{28}{ }_{72} \cdot 2 \mathrm{H}_{2} \mathrm{O}\right)$ may exist, and he preferred to set an arbitrary division between the two based on the Si/Al mole ratio. He terms those members of the series with Si/Al greater than 4.4 as clinoptilolite and those less than 4.4 as heulandites regardless of the large-radius cation content (Ba, Sr, Mg, Ca, Na, K). In general Boles (1972), Mumpton (1960), and 

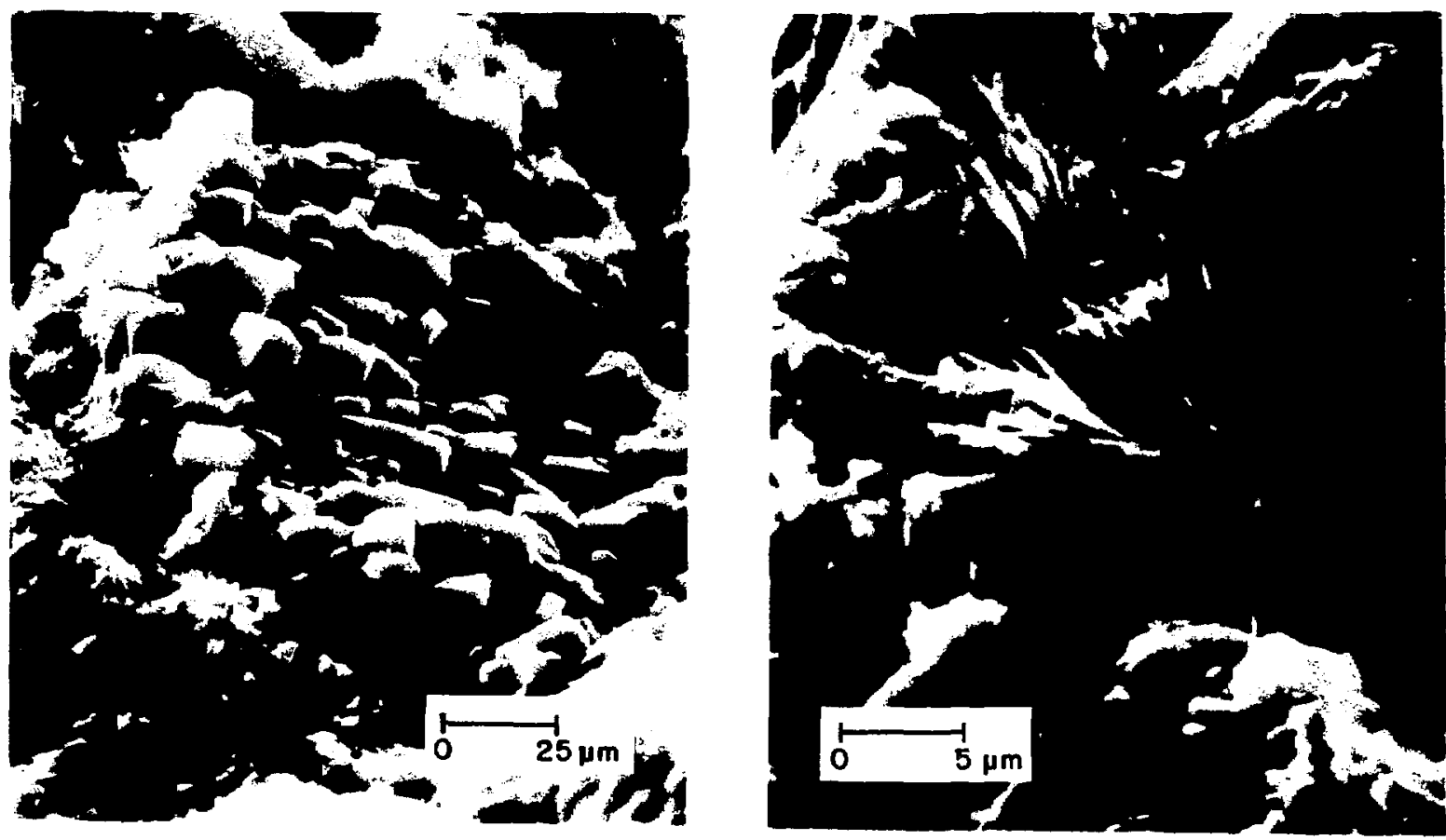

Fig. 15

SEM photographs of zeolites on a fracture surface in YM-34 (Topopah Sp:ings Member of Paintbrush Tuff).

A. Clinoptilolite(?) crystals (blocky), probably as a vug filling.
B. Detail of $A$, showing feathery crystals tentatively identified as erionite.

Aliotti (1972) found that those members of the series rich in divalent cations ( $\mathrm{Ca}, \mathrm{Ba}, \mathrm{Sr}, \mathrm{Mg}$ ) tended to contain more water than those in which monovalent cations ( $\mathrm{Na}, \mathrm{K}$ ) predominate. According to the nomenclature of Boles (1972) all the members of this series analyzed in Ue25-al should be classed as clinoptilolites except those filling fractures in sample YM-31 in the basal

vitrophyre of the Topopah Springs member. All the rest have Si/Al mole ratios in excess of 4.4 with some as high as 6.0 .

Mumpton (1960) proposed that clinoptilolite be distinguished from heulandite on the basis of a heating test with the latter becoming amorphous on heating to $450^{\circ} \mathrm{C}$ at 1 atm for a few hours and the former retaining a well-defined crystal structure to much higher temperatures. Both these minerals undergo a "polymorphic reaction" (Aliotti, 1972) in the range $200-400^{\circ} \mathrm{C}$. 
This appears to be a reversible displacive dehydration in which the cell volume shrinks by almost ten percent (Boles, 1972; Mumpton, 1960; Shepard and Starkey, 1964; Al iotti, 1967, 1972; Breger et al. 1970). In most cases, specimens showing higher $\mathrm{Si} / \mathrm{Al}$ ratios and higher monovalent to divalent cation ratios transformed to the collapsed structures at higher temperatures. It seems likely that this dehydration reaction accounts for the negative thermal expansions noted for non-welded tuff (A. Lappin, Sandia Laboratory, personal communication, 1979). The effect of water pressure on these reactions is currently under investigation by Los Al amos Scientific Laboratory.

As may be seen from the chemical analyses in the Appendix, the chemistry of clinoptilolite in UE25a-1 is somewhat variable. In general, the Si/A1 ratios are higher than commonly reported for clinoptilolites in the literature with a few ratios (e.g. YM-41) in excess of 6.0. In general the divalent cations ( $\mathrm{Ca}$ ) seem to predominate in the upper zeolitized zones while the monovalent cations, particularly $K$, predominate in the lower portions of the Bedded Tuff of Calico Hills. Calcium again predominates in the zeolitized horizons of the Crater Flat Tuff. It is not clear whether this is due to ground water action or the original composition of the glass.

Minor amounts of mordenite were observed as spherulitic cavity filling in the zeolitized horizons of the tuff of Crater Flat, both by x-ray and by electron microprobe techniques. Mordenite is characterized by low silica content $\left(\langle 55 \%)\right.$ and high alkali content $\left(>10 \% \mathrm{Na}_{2} \mathrm{O}+\mathrm{K}_{2} \mathrm{O}\right)$. Its presence may indicate slightly elevated temperatures of formation as suggested by Goto (1977) but more likely it reflects an enrichment of alkalis in ground water with depth (Hoover, 1968). Analcite and calcite were not observed in any of the cores from UE25a-1 but are common secondary phases in deeper samples of NTS tuff (Hoover, 1968, Heiken and Bevier, 1978). Erionite has been tentatively identified from SEM photographs of sample YM-34 (Fig. 15B).

Shepard and Starkey (1964) estimate that pyroclastic rocks may alter completely to zeolites in as little time as 10,000 years given complete water saturation at temperatures below $100^{\circ} \mathrm{C}$. Several zeolitized horizons are present in the lower zones of the 1.0 million-year-old Bandelier Tuff in Los Alamos County, N.M., indicating zones of ground water paleosaturation (Bailey and Smith, 1978; see Fig. 14). The fact that the bedded tuff unit of the Tiva Canyon Member is essentially unaltered is evidence that the unit probably has never been saturated since its emplacement. The current static water table is 
at approximately 470-m depth, approximately $80 \mathrm{~m}$ below the highest zone of zeolite minerals encountered, indicating that the water table has been at least $80 \mathrm{~m}$ higher than the current level in the geologic past.

VII. COMPARITIVE STRATIGRAPHY OF UE25a-1 and J-13

There are distinct changes in the thickness of pyroclastic flow units between drill holes UE25a-1 and J-13 despite the fact that the holes are located only about $6.1 \mathrm{~km}(3.8 \mathrm{mi})$ apart (Figs. 1 and 16$)$. These changes may be due either to thinning away from source areas or to paleotopography, as discussed below.

The Prow Pass Member of the Crater Flat Tuff thins from north to south away from the Sleeping Butte Caldera as would be expected with normal thinning of pyroclastic flows away from a vent.

The bedded, nonwelded tuffs of the two wells are both underlain by crater Flat Tuff and overlain by the Paintbrush Tuff. In UE25a-1, this unit has been tentatively identified as the 'Bedded Tuffs of Calico Hills' (Spengler et al., 1979); in well J-13, the possible equivalent unit is the 'Bedded Unit of the Paintbrush Tuff' (B. Crowe, personal communication). Whatever their source, petrologic evidence suggests that the units are correlative, as they are similar in texture and mineralogy. The observed thinning from north to south would be consistent with a source area of one of the calderas north of the drill sites.

The Topopah Springs Member of the Paintbrush Tuff thins from south to north, towards its source in the Claim Canyon cauldron. This could be due to greater erosion of the unit at UE25a-1, but is more likely due to lateral variations in pyroclastic flow thicknesses caused by pre-eruption topography. Byers et al. (1976) indicate that Basin and Range topography existed in this region prior to volcanic activity, so rapid changes in lateral thickness are quite possible.

The Tiva Canyon Member of the Paintbrush Tuff thins from $240 \mathrm{~m}$ at UE25a-1 to $70 \mathrm{~m}$ at $\mathrm{J}-13$. This difference is most likely due to erosional removal of the upper parts of the unit at the J-13 site. 


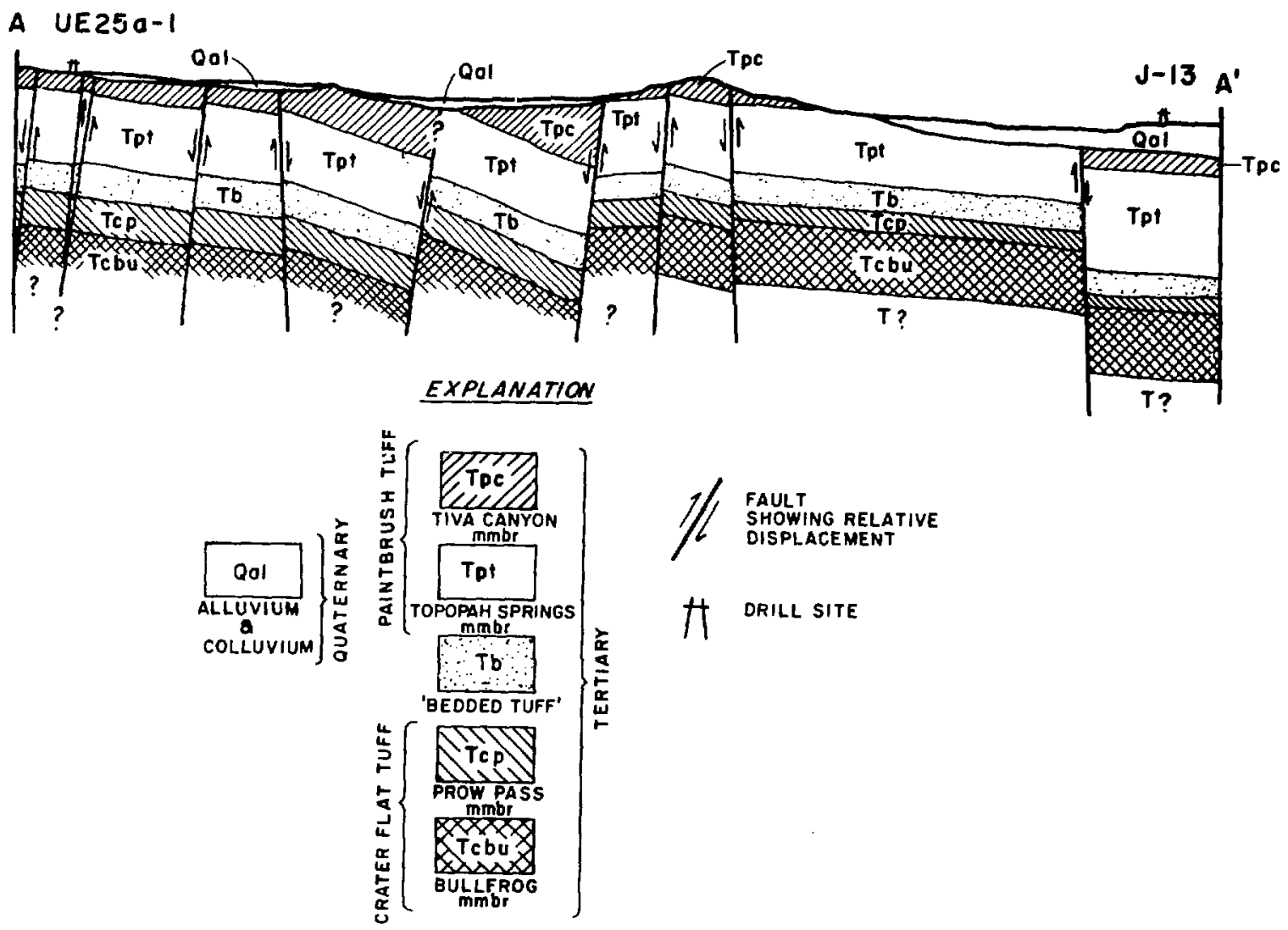

Fig. 16

Cross-section units between drill sites UE25a-1 and J-13. See Fig. 1 for location of $A$ and $A^{\prime}$.

\section{VIII. $\quad$ SUMMARY AND CONCLUSIONS}

Zeolitization of the tuff penetrated by the $\mathrm{J}-13$ hole has been described by Heiken and Bevier (1979) and is generally similar to that noted from core studies at drill hole UE25a-1. One possible difference is the occurrence of analcite and traces of erionite and phillipsite in the Bullfrog Member of the Crater Flat Tuff at J-13; the presence or absence of zeolites in this unit at UE25a-1 could not be determined as the drill hole penetrated only the upper 51 m. Also, zeolite mineralogy is more varied in the tuffs of $\mathrm{J}-13$; analcite, phillipsite, and erionite are present in addition to the clinoptilolite of the UE25a-1 tuffs. 
The occurrence of zeolites in tuff penetrated by the UE25a-1 and J-13 holes is similar to that described for other sequences of rhyolitic tephra where alteration was due to groundwater-glass interactions in open hydrologic systems (Walton, 1975; Hay and Sheppard, 1977).

The Yucca Mountain data suggest that the occurrence of zeolites in this area is restricted to low density, high porosity nonwelded tuffs which have been below the water table and have not been previously altered to alkali feldspar and $\mathrm{SiO}_{2}$. The absence of zeolites and presence of fresh glass in the lowermost Tiva Canyon and uppermost Topopah Springs samples (YM-5 and-6, 76.5 and $84.3 \mathrm{~m}$ depth respectively) indicate that portion of the stratigraphic section has not been below the water table for significant lengths of time. The absence of zeolites in the moderately to densely welded zones of the Topopah Springs, Prow Pass, and Bullfrog members is probably due to prohibitive mineralogy; alkali feldspar and $\mathrm{SiO}_{2}$ cannot react to form zeolites by interaction with ground water.

At present little can be inferred about the paleohydrology of the Yucca Mountain area and its relationship to zeolitization from the available data. Mineralogical, compositional, and textural similarities of the zeolitized tuffs are compatible with a single episode of zeolitization. Further detailed crystallographic, chemical, and isotopic characterization of the tuffs will be necessary to understand such relationships.

\section{ACKNOWLEDGMENTS}

We gratefully acknowledge the following: Roland Hagan for assistance on microprobe analyses; Dave Mann and his staff for thin section preparation; Shirley Mathews, Barbara Hahn, and Sue Noel for typing; Luween Smith for drafting; and the assistance of the U.S.G.S. Core Repository Staff at the Nevada Test Site. Bruce Crowe and Dave Vaniman provided many useful comments on an earlier version of the manuscript. Funding for this project was provided through the Nevada Nuclear Waste Investigations.

\section{REFERENCES}

1. A. Al iett $i$, "Heulanditi e clinoptiloti," Mineral. Petrogr. Acta $\underline{13}$, 119-138 (1967). 
2. A. Al ietti, "Polymorphism and Crystal Chemistry of Heulandite and Clinoptilolites," Am. Min. 57, p. 1448-1458 (1972).

3. R. A. Bailey and R. L. Smith, "Volcanic Geology of the Jemez Mountains, New Mexico," in Guidebook to Rio Grande Rift in New Mexico and Colorado, J. W. Hawley, Ed. (New Mexico Bur. Mines Min. Res. Circ. 163) 184-196 (1978).

4. J. R. Boles, "Composition, Optical Properties, Cell Dimensions, and Thermal Stability of Some Heulandite Group Zeolites," Am. Min. 57, p. 14631493.

5. I. A. Breger, J. C. Chandler, and P. Zubovic, "An Infrared Study of Water in Heulandite and Clinoptilolite," Am. Min. 55, p. 825-840 (1970).

6. F. M. Byers, Jr., W. J. Carr, P. P. Orkild, W. D. Quinlivan, and K. A. Sargent, "Volcanic Suites and Related Cauldrons of Timber Mountain--0asis Valley Caldera Complex, Southern Nevada," U.S. Geol. Surv. Prof. Pap. 919.

7. R. L. Christiansen, P. W. Lipman, W. J. Carr, F. M. Byers, Jr., P. P. Orkild, and K. A. Sargent, "Timber Mountain-Oasis Valley Caldera Complex of Southern Nevada," Geol. Soc. Am. Bul1. 88, 943-959 (1977).

8. E. F. Cook, "Stratigraphy of Tertiary Volcanic Rocks in Eastern Nevada,: Nevada Bur. Mines Report 11, 61 (1965).

9. R. V. Fisher, "Proposed Classification of Volcaniclastic Sediments and Rocks," Geol. Soc. Am. Bull. 72, 1409-1414 (1961).

10. Y. Goto, "Synthesis of Cl inoptilolite," Am. Min. 62, 330-332 (1977).

11. R. L. Hay and R. A. Sheppard, "Zeolites in Open Hydrologic Systems," in Mineralogy and Geology of Natural Zeolites, F.A. Mumpton, Ed. (Min. Soc. Am. Short Course Notes, Vol. 4) 93-102 (1977).

12. G. H. Heiken and M. L. Bevier, "Petrology of Tuff Units from the J-13 Drill Site, Jackass Flats, Nevada," Los Alamos Scientific Laboratory Report LA-7563-MS, 55 (1979).

13. D. L. Hoover, "Genesis of Zeolites, Nevada Test Site," in "Nevada Test Site," E. B. Eckel, Ed., Geol. Soc. Am. Mem. 110, 275-284 (1968).

14. P. W. Lipman, R. L. Christiansen, and J. T. O'Connor, "A Compositionally Zoned Ash-flow Shert in Southern Nevada," U.S. Geol. Surv. Prof. Pap. 524-F, F-1. - F-47 (1966).

15. P. W. Lipman and E. J. McKay, "Geologic Map of the Topopah Spring SW Quadrangle, Nye County, Nevada" U.S. Geol. Surv. Map GQ-439 (1965).

16. B. Mason and L. B. Sand, "Clinoptilolite from Patagonia, the Relationship Between Clinoptilolite and Heulandite," Am. Min. 45, 341-350 (1960).

17. F. A. Mumpton, "Clinoptilolite Redefined," Am. Min. 45, 351-369 (1960). 
18. C. S. Ross and R. L. Smith, "Ash-Flow Tuffs: Their Origin, Geologic Relations, and Identification," U.S. Geol. Surv. Prof. Pap. 366, 81 (1961).

19. A. 0. Shepard and H. C. Starkey, "Effect of Cation Exchange on the Thermal Behavior of Heulandite and Clinoptilolite," U.S. Geol. Surv. Prof. Pap. 475D, 89 (1964).

20. J. R. Smyth, B. M. Crowe, and P. M. Halleck, "Evaluation of the Concept of Terminal Storage of Radioactive Waste in Pyroclastic Rocks," in press.

21. R. W. Spengler, D. C. Muller, and R. B. Livermore, "Preliminary Report on the Geology and Geophysics of Drill Hole UE25a-1, Yucca Mountain, Nevada Test Site," U.S. Geol. Surv. Open-file Report 79-1244, 43 (1979).

22. A. W. Walton, "Zeolitic Diagenesis in 01 igocene Volcanic Sediments, Trans-Pecos Texas," Geol. Soc. Am. Bu11. 86, 615-624 (1975). 
MINERALOGY, PLTROGRAPHY, AND CHLMISTRY UF YUCCA MOUNTAIN SAMPLES

Following are petrographic descriptions, modes, chemical analyses, and normative compositions for samples from the Yucca Mountain exploratory drill hole UE25a-l. This information is given in order of increasing depth.

Sample descriptions are based on thin section petrography. The number in parentheses following the sample number is sample depth, in meters. Phenocryst compositions are based on molecular Cipw normative orthoclase (Or) and anorthite (An) contents calculated from electron microprobe analyses.

Modes in volume percent, based on 300 to 500 points, are given for major phases in each sample. Chemical analyses are given for those phases listed in the mode which are footnoted.

Chemical analyses are based on electron microprobe results. Average andyses are used when possible; the number of analyses is given in parentheses under the column heading. Standard deviations are given in parentheses beside the average oxide concentrations. For analyses of mixtures of phases, the size of the standard deviation indicates co.position variability rather than analytical uncertainty.

CIPW normative compositions in mole percent, calculated only for phases consisting of $\mathrm{SiO}_{2}$ and/or feldspar, follow the chemical analyses. As the total mafic content is usually low (less than 2 mole percent), normative quartz (Qz), orthoclase $(O r)$, albite $(A b)$, and anorthite $(A n)$ concentrations are recalculated to $100 \%$.

Molecular Si/Al ratios follow the normative compositions for zeolite analyses; these are calculated from the electron microprobe analyses.

Phase identifications are based on the combination of petrographic, $x$-ray, and microprobe analyses. Abbreviations used are as follow:

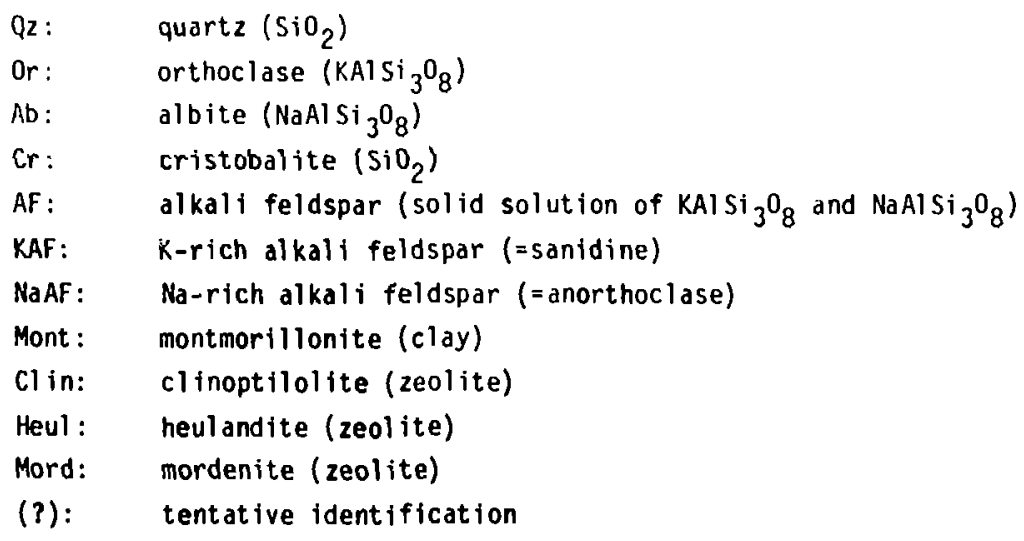




\section{Iive Canyon Mesber of the Paintbrush Tuff}

MM-1 $(25.5 \mathrm{~m})$ : Devitrified densely welded vitric tuff. Relict shards predominate in this rock; these are outlined by chains of $0.2 \mu \mathrm{m}$ diameter grains of hematite. Shards are replaced by color?ess, 1-2 um wide, 10-30 um long phases wich srow normal to grain boundaries. Former pumice clasts are replaced by spherulitic, equigranular colorless phases, and by vugs $50-400$ un long.

Phenocrysts consist of a few percent sanidine $\left(0 r_{88}\right)$ and magnetite.

MODE

Phase

Yol une Percent

Relict shards ${ }^{\text {a }}$

Fibrous

Henatite

41.3

Interstitial

3.3

15.3

Relict punice

Spherulites $^{b} \quad 21.7$

Fine granular $\quad 12.0$

Coarse crystallinec $\quad 3.0$

Phenocrysts

Sanidine $\quad 3.0$

Opaques 0.3

Totd] 99.9

$\begin{array}{lccc}\text { AMLYSES } & \mathrm{d} & \mathrm{b} & \mathrm{c} \\ \text { Oxide } & (33) & (13) & (11) \\ \mathrm{SiO}_{2} & 78.94(2.52) & 76.77(2.56) & 6 \mathrm{B.93}(2.46) \\ \mathrm{Al}_{2} \mathrm{O}_{3} & 12.48(1.09) & 13.68(1.85) & 17.54(0.90) \\ \mathrm{BaO} & 0.01(0.01) & 0.01(0.00) & 0.00(0.01) \\ \mathrm{CaO} & 0.08(0.03) & 0.08(0.01) & 0.06(0.01) \\ \mathrm{Na}_{2} \mathrm{O} & 3.22(0.35) & 3.86(0.70) & 5.00(0.24) \\ \mathrm{K}_{2} \mathrm{O} & 5.07(0.68) & 5.09(0.53) & 7.56(0.88) \\ \text { Total } & 99.80 & 99.49 & 99.09 \\ & & & \\ Q & 38.83 & 33.01 & 10.01 \\ \mathrm{Or} & 30.91 & 30.92 & 44.73 \\ \text { Ab } & 29.83 & 35.65 & 44.96 \\ \text { An } & 0.43 & 0.43 & 0.29 \\ & \text { Cr+KAF } & \text { Cr+KAF } & \text { Cr+KAF }\end{array}$


YM-2 (48.0): Devitrified densely welded vitric tuff. This rock is similar to MM-1. Relict shards consist of three phases, each grading into the others. Phase I consists of 10 um-diam with sub-um hematite grains evenly dispersed. Phase 2 consists of well-developed spherulites, 50-150 $\mathrm{m}$ in diameter. Phase 3 consists of a granular, colorless, 20 um diameter phase replacing the coarser shards; this is also found filling small voids.

Lenticular vugs (up to $3 \mathrm{~m}$ long) are zoned; edges consist af elongate phases ( 10 um wide) and centers are filled with equant, colorless phases 50-100 $\mathrm{\mu m}$ in diameter.

Flattened pumice pyroclasts are up to 8 m long and are replaced by both coarse spherulitec and equant colorless phases. Phenocrysts include sanidine $\left(0 r_{39}\right)$ plagioclase, sphene, hornblende (oxidized to hematite), and magnetite.

MODE

\begin{tabular}{|c|c|}
\hline Phase & Vol une $\mathrm{Pe}$ \\
\hline \multicolumn{2}{|l|}{ Shards and matrix } \\
\hline Very fine granular & 41.9 \\
\hline Fine spherulites ${ }^{b}$ & 20.8 \\
\hline Medium granular & 25.2 \\
\hline Vugs rims ${ }^{c}$ and cores ${ }^{d, e}$ & 8.5 \\
\hline \multicolumn{2}{|l|}{ Phenocrysts } \\
\hline Sanidine & 3.4 \\
\hline Plagioclase & 0.2 \\
\hline Sphene & $\mathrm{tr}$ \\
\hline Hornblende & $\operatorname{tr}$ \\
\hline Opaques & $\operatorname{tr}$ \\
\hline Total & 100.0 \\
\hline
\end{tabular}

\begin{tabular}{|c|c|c|c|c|c|}
\hline ANALYSES & $a$ & b & c & d & e \\
\hline 0xide & (13) & (11) & (9) & $(6)$ & (4) \\
\hline $\mathrm{SiO}_{2}$ & $72.09(3.85)$ & $77.43(4.57)$ & $70.98(0.43)$ & $68.81(1.45)$ & $95.07(0.59)$ \\
\hline A) ${ }_{2} \mathrm{O}_{3}$ & $15.97(2.58)$ & $12.75(2.48)$ & $17.50(0.70)$ & $18.31(0.53)$ & $0.36(0.04)$ \\
\hline $\mathrm{BaO}$ & $0.00(0.00)$ & $0.00(0.00)$ & $0.00(0.00)$ & $0.00(0.00)$ & $0.00(0.05)$ \\
\hline $\mathrm{CaO}$ & $0.04(0.01)$ & $0.06(0.02)$ & $0.49(0.01)$ & $0.05(0.04)$ & $0.01(0.01)$ \\
\hline $\mathrm{Na}_{2} \mathrm{O}$ & $4.11(0.42)$ & $3.28(0.45)$ & $4.99(0.53)$ & $5.00(0.71)$ & $0.11(0.02)$ \\
\hline $\mathrm{K}_{2} \mathrm{O}$ & $7.20(0.92)$ & $5.22(1.49)$ & $6.96(0.83)$ & $7.20(1.64)$ & $0.02(0.01)$ \\
\hline Total & 99.41 & 98.74 & 100.92 & 99.37 & 95.57 \\
\hline $\mathrm{Q}$ & 19.28 & 36.90 & $: 3.01$ & 11.31 & \\
\hline Or & 43.11 & 32.12 & 40.48 & 43.03 & \\
\hline$A b$ & 37.41 & 30.68 & 44.12 & 45.41 & \\
\hline \multirow[t]{2}{*}{ An } & 0.20 & 0.31 & 2.39 & 0.26 & \\
\hline & $\mathrm{Cr}+\mathrm{KAF}$ & $\mathrm{Cr}+\mathrm{KAF}$ & $C r+K A F$ & $\mathrm{Cr}$ & \\
\hline
\end{tabular}


MM-3 (57.0): Devitrified partly welded vitric tuff. This rock consists mostly of poorly preserved relict shards. The most comon phase is medium brown and finely crystalline (1-2:-.: tite mark the occasional pyroclast boundaries.

Small lenticular voids are lined with 1-2 um wide colorless needles of a low-birefringence phase. Pumice pyroclasts have been replaced by colorless to pale brown spherulites. Individual crystals are 3-5 um wide and up to $200 \mu \mathrm{m}$ long.

Phenocrysts include sanidine $\left(0 r_{38}\right)$, sphene, and magnetite.

\begin{tabular}{|c|c|c|c|c|}
\hline \multicolumn{5}{|l|}{ MODE } \\
\hline Phase & & Volume Percent & & \\
\hline Shards ${ }^{a}$ and & matrix & 63.5 & & \\
\hline \multicolumn{5}{|c|}{ Pumices } \\
\hline \multicolumn{5}{|c|}{ Spherulites ${ }^{b, c}$ and } \\
\hline \multicolumn{2}{|c|}{ fine grained } & 19.4 & & \\
\hline \multicolumn{2}{|c|}{ Vug filling } & 6.0 & & \\
\hline \multicolumn{5}{|l|}{ Phenocrysts } \\
\hline \multicolumn{2}{|l|}{ Sanidine } & 4.2 & & \\
\hline \multicolumn{2}{|l|}{ Sphene } & 0.4 & & \\
\hline \multicolumn{2}{|l|}{ Opaques } & $\operatorname{tr}$ & & \\
\hline \multicolumn{2}{|l|}{ Voids } & 5.8 & & \\
\hline \multicolumn{2}{|l|}{ Lithics } & $\operatorname{tr}$ & & \\
\hline \multicolumn{2}{|l|}{ Other } & 0.6 & & \\
\hline \multicolumn{2}{|l|}{ Total } & 99.9 & & \\
\hline \multicolumn{2}{|l|}{ AKALYSES } & 0 & c & d \\
\hline oxide & (10) & (8) & (1) & (7) \\
\hline \multirow{3}{*}{$\begin{array}{l}\mathrm{SiO}_{2} \\
\mathrm{Al}_{2} \mathrm{O}_{3} \\
\mathrm{BaO}\end{array}$} & $78.74(1.46)$ & $70.83(1.55)$ & 92.71 & $69.60(0.84)$ \\
\hline & $11.54(1.75)$ & $17.23(0.14)$ & 1.49 & $17.92(0.40)$ \\
\hline & $0.00(0.00)$ & $0.01(0.01)$ & 0.00 & $0.01(0.02)$ \\
\hline $\mathrm{Ca} 0$ & $0.07(0.00)$ & $0.09(0.02)$ & 0.01 & $0.11(0.03)$ \\
\hline $\mathrm{Na}_{2} \mathrm{O}$ & $2.78(0.03)$ & $3.81(0.21)$ & 0.27 & $3.84(0.31)$ \\
\hline$K_{2}{ }^{0}$ & $6.00(0.52)$ & $8.62(0.22)$ & 0.20 & $8.81(0.94)$ \\
\hline Total & 99.13 & 100.59 & 94.69 & 100.29 \\
\hline$Q z$ & 37.56 & 14.35 & & 12.41 \\
\hline Or & 36.42 & 50.96 & & 52.36 \\
\hline$A b$ & 25.65 & 34.23 & & 34.68 \\
\hline \multirow[t]{2}{*}{ An } & 0.36 & 0.47 & & 0.55 \\
\hline & $\mathrm{Cr}+\mathrm{KAF}$ & $\mathrm{Cr}+\mathrm{KAF}$ & $\mathrm{Cr}$ & $C r+K A F$ \\
\hline
\end{tabular}


YM-4 (68.9): Non-welded vitric-crystal tuff. This rock consists of equant, subrounded pumice pyroclasts up to 15 ma long in a matrix of shards and finely crystalline ( $<2 \mu \mathrm{m}$ diam) phases.

Phenocrysts include plagioclase (An $16-20)$ (many as fractured glomerocrysts), biotite, magnetite, sanidine (0r 52 ), oxyhornblende, and orthopyroxene(?). Lithic fragments consist predominanty of older welded tuffs and lavas.

MODE

Phase

Putices ${ }^{a}$

Shards ${ }^{b}$

olume Percent

47.5

36.9

Phenocrysts

Plagioclase

Sanidine

Biotite

Hornblende

Opaques

Lithic fragments

Total

12.0

0.2

1.0

tr

0.7

1.7

100.00

$\begin{array}{ccc}\text { ANaLYSES } & a & b \\ \text { Oxide } & (3) & (11) \\ \mathrm{SiO}_{2} & 71.77(0.01) & 72.07(1.22) \\ \mathrm{Al}_{2} \mathrm{O}_{3} & 12.83(0.05) & 12.85(0.24) \\ \mathrm{FeO}_{\mathrm{MgO}} & 0.65(0.05) & 0.73(0.09) \\ \mathrm{BaO} & 0.04(0.00) & 0.05(0.01) \\ \mathrm{CaO} & 0.05(0.02) & 0.06(0.06) \\ \mathrm{Na}_{2} \mathrm{O} & 0.51(0.01) & 0.54(0.03) \\ \mathrm{K}_{2} \mathrm{O} & 3.07(0.02) & 2.99(0.16) \\ \text { Total } & 5.25(0.04) & 5.17(0.17) \\ & 94.16 & 94.46\end{array}$

$\begin{array}{lrr}\text { Qz } & 32.69 & 33.69 \\ \text { Or } & 34.11 & 33.66 \\ \text { Ab } & 30.32 & 29.59 \\ \text { An } & 2.88 & 3.07 \\ & \text { Glass } & \text { Glass }\end{array}$


M-5 (76.5): Nonwelded vitric-crystal tuff. This rock is an airfall (?) tuff composed of 2-30 mm long equant to slightly elongate pumice pyroclasts in a matrix of shards. Glass pyroclasts are intact except for slightly ragged surfaces wich indicate some weathering.

Abundant phenocrysts include $\mathrm{plagioclase}\left(\mathrm{An}_{25-30}\right)$, oxidized biotite, sanidine $\left(0 \mathrm{r}_{43}\right)$, magnetite, orthopyroxene, and glamerocrysts of sanidine and plagioclase. Lithic fragments consist of clasts of an imature sandstone.

MODE

Phase

Punice ${ }^{a}$

Shards ${ }^{b}$

Volume Percent

36.0

48.4

Phenocrysts

Plagioc lase

Biotite

Sanidine

Opaques

Lithic fragments

Voids

4.8

3.2

2.7

0.2

4.3

0.5

Total

100.1

$\begin{array}{ccc}\text { AMALYSES } & \mathrm{a} & \mathrm{b} \\ \text { Oxide } & (3) & (7) \\ \mathrm{SiO}_{2} & 68.25(0.30) & 68.60(0.23) \\ \mathrm{Al}_{2} \mathrm{O}_{3} & 14.66(0.33) & 14.11(0.36) \\ \mathrm{FeO}_{\mathrm{O}} & 1.59(0.14) & 1.53(0.10) \\ \mathrm{MgO} & 0.17(0.01) & 0.18(0.03) \\ \mathrm{BaO} & 0.09(0.11) & 0.00(0.08) \\ \mathrm{CaO} & 0.79(0.04) & 0.83(0.07) \\ \mathrm{Na}_{2} \mathrm{O} & 3.75(0.12) & 2.91(0.14) \\ \mathrm{K}_{2} \mathrm{O} & 5.69(0.06) & 5.42(0.11) \\ \mathrm{Total}_{\mathrm{a}} & 94.98 & 93.58 \\ & & \\ \mathrm{Qz}_{\mathrm{z}} & 21.71 & 29.11 \\ \mathrm{Or} & 36.84 & 36.45 \\ \mathrm{Ab} & 36.96 & 29.75 \\ \mathrm{An} & 4.48 & 4.69 \\ & \mathrm{Glass} & \mathrm{Glas5}\end{array}$


YM-6 (84.3): Densely welded vitric-crystal tuff. Compacted pumice pyroclasts, 0.5-1.2 mm long, are evenly dispersed throughout a matrix of 20-600 $\mu \mathrm{m}$ long compressed shards. Within the pumice pyroclasts, former vesicles are marked by lines of microlites.

Phenocrysts include sanidine $\left(0 \mathrm{r}_{41}\right)$, plagioclase $\left(\mathrm{An}_{31-35)}\right.$, oxidized biotite, magnetite, spinel(?), and orthopyroxene. Numerous lithic fragnents include devitrified rhyolitic lava, welded tuff, and rhyolitic glass clasts.

\begin{tabular}{|c|c|c|}
\hline \multicolumn{3}{|l|}{ MODE } \\
\hline Phase & & Volume Percent \\
\hline Punices ${ }^{a}$ & & 24.9 \\
\hline Shards ${ }^{b}$ & & 56.5 \\
\hline \multicolumn{3}{|c|}{ Phenocrysts } \\
\hline \multicolumn{2}{|c|}{ Sanidine } & 10.7 \\
\hline \multicolumn{2}{|c|}{ Plagioclase } & 3.3 \\
\hline \multicolumn{2}{|c|}{ Orthopyroxene } & 2.1 \\
\hline \multicolumn{2}{|c|}{ Biotite } & 0.5 \\
\hline \multicolumn{2}{|c|}{ Opaques } & 0.2 \\
\hline \multicolumn{2}{|c|}{ Lithic fragnents } & 1.9 \\
\hline \multicolumn{2}{|l|}{ Total } & 100.1 \\
\hline \multicolumn{2}{|l|}{ ANAL YSES } & $b$ \\
\hline \multicolumn{2}{|l|}{ Oxide } & (5) \\
\hline & $67.34(1.07)$ & $70.46(3.22)$ \\
\hline $\mathrm{Al}_{2} \mathrm{O}_{3}$ & $15.04(0.30)$ & $13.38(2.08)$ \\
\hline \multirow{2}{*}{$\begin{array}{l}\mathrm{FeO} \\
\mathrm{Mg} 0\end{array}$} & $0.86(0.52)$ & $0.92(0.78)$ \\
\hline & $0.14(0.11)$ & $0.05(0.09)$ \\
\hline $\mathrm{BaO}$ & $0.05(0.05)$ & $0.07(0.12)$ \\
\hline $\mathrm{CaO}$ & $0.75(0.24)$ & $0.43(0.31)$ \\
\hline $\mathrm{Na}_{2} \mathrm{O}$ & $3.67(0.51)$ & $3.48(0.75)$ \\
\hline $\mathrm{K}_{2} \mathrm{O}$ & $6.64(0.61)$ & $5.92(0.36)$ \\
\hline Total & 94.51 & 94.71 \\
\hline $0 z$ & 18.01 & 25.82 \\
\hline or & 42.32 & 37.88 \\
\hline$A b$ & 35.55 & 33.84 \\
\hline \multirow[t]{2}{*}{ An } & 4.11 & 2.45 \\
\hline & Glass & Gl ass \\
\hline
\end{tabular}


YM-7 (102.0): Devitrified densely welded vitric-crystal tuff. This tuff consists of relict pumices within a matrix of relict shards which have been replaced by finely crystalline, colorless, fibrous to granular sub-um phases.

Lenticular relict pumices are zoned from rims of fibrous, 3-5 um wide grains up to 200 um long to hollow centers lined with sub-to euhedral tabular colorless phases.

Large $\left(2-3 \mathrm{~cm}\right.$ long) anorthoclase $\left(0 \mathrm{r}_{30-33}\right)$ crystals comprise the bulk of the phenocrysts; others include magnetite and oxidized biotite.

\begin{tabular}{|c|c|c|c|c|}
\hline \multicolumn{5}{|l|}{ MODE } \\
\hline \multicolumn{2}{|l|}{ Phase } & Volume Percent & & \\
\hline \multicolumn{2}{|c|}{ Shards ${ }^{a}$ and matrix } & 48.6 & & \\
\hline \multicolumn{5}{|c|}{ Pumice } \\
\hline \multicolumn{2}{|c|}{ Fine rims ${ }^{b}$} & 20.8 & & \\
\hline \multicolumn{2}{|c|}{ Spherul ites } & 2.2 & & \\
\hline \multicolumn{2}{|c|}{ Coarse vug $f i 1 f^{c, d}$} & 9.0 & & \\
\hline \multicolumn{5}{|c|}{ Phenocrysts } \\
\hline \multicolumn{2}{|c|}{ Anorthoclase } & 15.1 & & \\
\hline \multicolumn{2}{|l|}{ Opaques } & 1.3 & & \\
\hline \multicolumn{2}{|c|}{ Cl inopyroxene } & 0.4 & & \\
\hline \multicolumn{2}{|l|}{ Biotite } & 0.4 & & \\
\hline \multicolumn{2}{|l|}{ Voids } & 2.2 & & \\
\hline \multicolumn{2}{|l|}{ Total } & 100.0 & & \\
\hline \multicolumn{2}{|l|}{ ANALYSES } & b & $c$ & $d$ \\
\hline \multicolumn{2}{|l|}{ Oxide } & (10) & (5) & (4) \\
\hline $\mathrm{SiO}_{2}$ & $74.56(2.37)$ & $69.41(1.80)$ & $67.81(0.14)$ & $97.73(0.53)$ \\
\hline \multirow{2}{*}{$\begin{array}{l}\mathrm{Al}_{2} \mathrm{O}_{3} \\
\mathrm{BaO}\end{array}$} & $13.80(1.52)$ & $17.42(0.93)$ & $18.64(0.12)$ & $1.31(0.09)$ \\
\hline & $0.11(0.04)$ & $0.12(0.01)$ & $0.12(0.03)$ & $0.10(0.04)$ \\
\hline $\mathrm{CaO}$ & $0.49(0.03)$ & $0.61(0.08)$ & $0.63(0.09)$ & $0.01(0.02)$ \\
\hline $\mathrm{Na}_{2} \mathrm{O}$ & $3.76(0.38)$ & $5.17(0.6 !)$ & $5.44(0.30)$ & $0.31(0.00)$ \\
\hline \multirow{2}{*}{$\begin{array}{r}K_{2}{ }^{0} \\
\text { Total }\end{array}$} & $5.91(0.92)$ & $6.67(0.14)$ & $7.16(0.37)$ & $0.16(0.05)$ \\
\hline & 98.63 & 99.39 & 99.81 & 99.63 \\
\hline$Q z$ & 27.32 & 11.48 & 6.70 & \\
\hline Or & 35.59 & 39.17 & 41.77 & \\
\hline$A b$ & 34.42 & 46.14 & 48.23 & \\
\hline \multirow[t]{2}{*}{ An } & 2.68 & 3.21 & 3.31 & \\
\hline & Cr+KAF & $C r+K A F$ & KAF & $\mathrm{Cr}$ \\
\hline
\end{tabular}


YM-8 (137.2): Devitrified densely welded vitric tuff. Pyroclasts within this rock have been replaced with finely crystalline ( $<3 \mu \mathrm{m} d i a m$ ) colorless, fibrous phases. Relict textures are difficult to define; relict punices are visible only due to subtle color changes.

Sanidine $\left(0 r_{45}\right)$ is the most common phenocryst, with lesser amounts of plagioclase (An 17-21), magnetite, and biotite.

\begin{tabular}{|c|c|c|c|c|}
\hline \multicolumn{5}{|l|}{ MODE } \\
\hline Phase & & Volume Percent & & \\
\hline \multicolumn{5}{|l|}{ Matrix } \\
\hline \multicolumn{5}{|c|}{ Very fine granular } \\
\hline \multicolumn{2}{|c|}{ to fibrous } & 70.7 & & \\
\hline \multicolumn{2}{|c|}{ Spherul ites $^{c}$} & 10.7 & & \\
\hline \multicolumn{2}{|c|}{ Authigenic patches } & 15.6 & & \\
\hline \multicolumn{5}{|c|}{ Phenocrysts } \\
\hline \multicolumn{5}{|c|}{ Sanidine and } \\
\hline \multicolumn{2}{|c|}{ plagioclase } & 2.6 & & \\
\hline \multicolumn{2}{|l|}{ Biotite } & $\operatorname{tr}$ & & \\
\hline \multicolumn{2}{|l|}{ Opaques } & 0.5 & & \\
\hline \multicolumn{2}{|l|}{ Total } & 100.1 & & \\
\hline ANALYSES & $a$ & b & c & $d$ \\
\hline Oxide & (5) & (9) & $(2)$ & (9) \\
\hline $\mathrm{SiO}_{2}$ & $77.57(3.66)$ & $72.82(1.93)$ & $64.61(0.98)$ & $99.32(0.31)$ \\
\hline $\mathrm{Al}_{2} \mathrm{O}_{3}$ & $13.17(1.60)$ & $15.48(1.64)$ & $17.50(0.68)$ & $0.66(0.19)$ \\
\hline $\mathrm{FeO}$ & $0.30(0.12)$ & ND & $0.13(0.04)$ & ND \\
\hline $\mathrm{MgO}$ & $0.00(0.01)$ & MO & $0.00(0.00)$ & ND \\
\hline $\mathrm{BaO}$ & $0.20(0.06)$ & $0.07(0.01)$ & $0.05(0.08)$ & $0.03(0.03)$ \\
\hline $\mathrm{CaO}$ & $0.30(0.05)$ & $0.37(0.09)$ & $0.29(0.04)$ & $0.01(0.01)$ \\
\hline $\mathrm{Na}_{2} \mathrm{O}$ & $4.03(0.80)$ & $3.76(0.37)$ & $4.74(0.55)$ & $0.26(0.06)$ \\
\hline$K_{2} 0$ & $5.55(1.36)$ & $7.52(0.89)$ & B. $79(0.38)$ & $0.03(0.01)$ \\
\hline Total & 101.12 & 100.02 & 96.11 & 100.31 \\
\hline Qz & 29.57 & 19.77 & 2.71 & \\
\hline Or & 32.78 & 44.46 & 53.18 & \\
\hline$A b$ & 36.18 & 33.80 & 43.59 & \\
\hline \multirow[t]{2}{*}{ An } & 1.46 & 1.97 & 0.52 & \\
\hline & $\mathrm{Cr}+\mathrm{KAF}$ & $\mathrm{Cr}+\mathrm{KAF}$ & KAF & $\mathrm{Cr}$ \\
\hline
\end{tabular}


M-9 (143.0): Devitrified densely welded vitric tuff. This tuff consists of relict pumice pyroclasts in a matrix of compacted relict shards. Spherulites developed in relict pumices cross pyroclast boundaries. Small (30-100 un diam) patches of equant, colorless phases are dispersed throughout the relict pyroclasts. These patches are rimmed with finely crystalline fibrous phases.

Lenticular vugs are zoned; rims consist of fibrous to granular colorless phases and centers consist of coarse, euhedral, colorless phases.

Anorthoclase $\left(0 r_{25}\right)$ is the dominant phenocryst; plagioclase $\left(A n_{28}\right)$ and magnetite occur in lesser amounts. Occasional fractures are either parallel or normal to the fabric.

MODE

Phase

Shards ${ }^{\mathrm{a}}$ and matrix

Punice b

Authigenic patches $c, d$

Phenocrysts

Anorthoclase

Plagioclase

Opaques

Total

AMALYSES

Oxide

$\mathrm{SiO}_{2}$

$\mathrm{Al}_{2} \mathrm{O}_{3}$

$\mathrm{FeO}$

$\mathrm{MgO}$

BaO

CaO

$\mathrm{Na}_{2} \mathrm{O}$

$\mathrm{k}_{2} \mathrm{O}$

Total

\section{Qz}

Or

Ab

An
Volune Percent

54.0

28.5

15.4

1.6

0.2

0.2

99.9

$\begin{array}{cc}c & d \\ (2) & (3) \\ 66.69(1.14) & 97.32(0.93) \\ 17.83(0.56) & 0.58(0.11) \\ 0.25(0.02) & 0.02(0.04) \\ 0.00(0.00) & 0.00(0.00) \\ 0.13(0.15) & 0.04(0.01) \\ 0.15(0.04) & 0.00(0.00) \\ 4.39(0.06) & 0.33(0.07) \\ 10.39(0.08) & 0.06(0.05) \\ 99.83 & 98.35\end{array}$

2.69

61.37

35.94

0.00

KAF
$\mathrm{Cr}$ 
YM-20 (206.4): Devitrified moderately welded vitric-1ithic tuff. The 'matrix' of this rock consists of relict shards 200-400 um long and an interstitial colorless to tan, fine-grained (up to 8 um in diameter) phase. Larger relict shards and pumices are roughly zoned, from rims of colorless, <10 um, granular phases to coarser (60-200 um diam) colorless, sub- to anhedral phases in the centers.

Rounded plagioclase (An 16 ) is the most abundant phenocryst with minor amounts of sanidine (Or 58 ). quartz, and biotite. Glomerocrysts of biotite, K-feldspar, and plagioclase are also present. Abundant lithic fragments consist predominantly of older welded tuff clasts, 0.3 to 4 min in diameter.

MODE

Phase

Shard $s^{D}$ and matrix

Pumices

Fine granular

Coarse authigenic patches $c, d$

Phenocrysts

Plagioclase

Sanidine

Lithic fragments

Unfilled fractures

Total

\section{ANALYSES}

Oxide

$\mathrm{SiO}_{2}$

$\mathrm{Al}_{2} \mathrm{O}_{3}$

$\mathrm{FeO}$

$\mathrm{MgO}$

BaO

$\mathrm{CaO}$

$\mathrm{Na}_{2} \mathrm{O}$

$\mathrm{K}_{2} \mathrm{O}$

Total

\section{Qz}

Or

$A b$

An
Volume Percent

71.8

8.9

8. 5

0.4

tr

9.5

1.0

100.1
(3)

$76.20(1.05)$

$11.68(0.23)$

$0.50(0.07)$

$0.00(0.00)$

$0.07(0.06)$

$0.22(0.05)$

$3.31(0.17)$

$5.86(0.67)$

97.84

33.16

36.29

30.55

0.00

$\mathrm{Cr}+\mathrm{KAF}$

\section{b}

(2)

$72.06(1.74)$

$11.41(0.07)$

$0.45(0.05)$

$0.00(0.00)$

$0.00(0.00)$

$0.46(0.14)$

$4.21(0.80)$

$4.47(3.06)$

93.05

31.31

29.12

39.56

0.00

$\mathrm{Cr}+\mathrm{AF}$ c

$97.96(0.68)$

$0.31(0.05)$

$0.00(0.04)$

$0.00(0.00)$

$0.11(0.09)$

$0.00(0.00)$

$0.18(0.04)$

$0.00(0.01)$

98.56

$\begin{array}{cc} & 5.61 \\ & 62.52 \\ & 31.87 \\ & 0.00 \\ C r & \text { KAF }\end{array}$


M-21 (223.3): Devitrified moderately welded vitric tuff. The matrix of this tuff consists of relict shards up to 1 mm Tong and finer grained : $\left.10 \mathrm{um}_{\mathrm{m}} \mathrm{diam}\right)$ interstitial phases. Shards are replaced with fibrous, $70-100$ um $10 n g$, 3-5 um wide phases. Relict pumices with indistinct boundaries consist of three phases: (1) a fine-grained, 2-10 $\mu$ miameter granular phase; (2) a fibrous to spherulitic phase (usually concentrated along punice boundaries); and (3) sub- to euhedral, 30-100 $\mathrm{um}$ diameter colorless phases.

Phenocrysts ronsist of sub- to euhedral fractured plagioclase (An ${ }_{11}$ ), magnetite, biotite, and rounded quartz. Lithic fragments are rare.

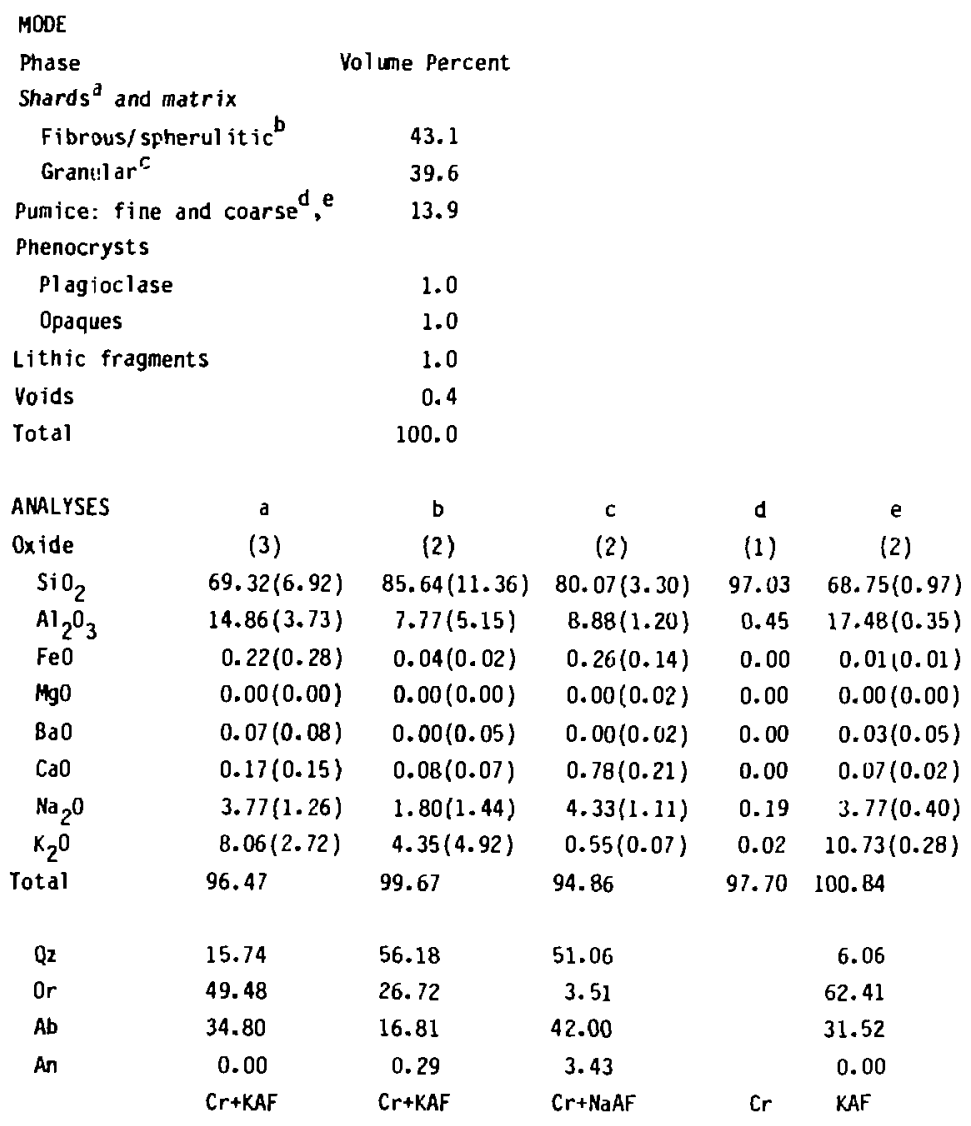


YM-17 (226.8): Devitrified moderately welded vitric tuff. Most of this rock consists of relict shards replaced by fibrous, $33 \mu \mathrm{m}$ wide, 40-100 $\mu \mathrm{m}$ long phases, outlined by chains of sub-um equant to dendritic hematite grains. Interstitial phases are colorless to tan, equigranular, and $33 \mu \mathrm{m}$ diameter. Relict pumice pyroclasts have been replaced by spherulites up to $B \mathrm{~mm}$ in diameter, and sub- to euhedral tabular colorless phases, 20 to $100 \mathrm{um}$ long.

Plagioclase $\left(A_{14-55}\right)$ is the major phenocryst phase, and occurs as fractured an- to euhedral grains up to 2 cm long. Fractured sub- to euhedral sanidine $\left(0 r_{57}\right)$, oxidized biotite, magnetite, and quartz also occur. Plagioclase, quart $z$, and $K$-feldspar somet imes exist as glomerocrysts.

\begin{tabular}{|c|c|c|c|c|c|}
\hline \multicolumn{6}{|l|}{ MODE } \\
\hline \multicolumn{2}{|l|}{ Phase } & \multicolumn{4}{|l|}{ Volume Percent } \\
\hline \multicolumn{2}{|c|}{ Shards and matrix } & 62.9 & & & \\
\hline \multicolumn{6}{|l|}{ Pumice } \\
\hline \multicolumn{6}{|c|}{ Fibrous and } \\
\hline \multicolumn{2}{|c|}{ Coarse crystalline ${ }^{e}$} & 8.8 & & & \\
\hline \multicolumn{2}{|c|}{ Authigenic patches ${ }^{c, d}$} & 4.8 & & & \\
\hline \multicolumn{6}{|c|}{ Phenocrysts } \\
\hline \multicolumn{2}{|c|}{ Plagioclase } & 1.8 & & & \\
\hline \multicolumn{2}{|c|}{ Biatite } & 0.2 & & & \\
\hline \multicolumn{2}{|c|}{ Lithic fragments } & 0.4 & & & \\
\hline \multicolumn{2}{|l|}{ Total } & 100.2 & & & \\
\hline \multicolumn{2}{|l|}{ ANALYSES } & b & c & d & e \\
\hline \multicolumn{2}{|l|}{ 0xide } & (4) & (1) & (9) & (5) \\
\hline $\mathrm{SiO}_{2}$ & $73.09(1.62)$ & $81.02(3.18)$ & 95.98 & $66.25(0.11)$ & $38.10(4.47)$ \\
\hline \multirow{2}{*}{$\begin{array}{l}\mathrm{Al}_{2} 2_{3} \\
\mathrm{FeO}\end{array}$} & $11.33(0.16)$ & $10.70(1.18)$ & 1.19 & $17.45(0.09)$ & $11.17(2.40)$ \\
\hline & $0.54(0.11)$ & $0.20(0.10)$ & 0.05 & $0.09(0.03)$ & $0.67(0.59)$ \\
\hline $\mathrm{MgO}$ & $0.00(0.07)$ & $0.00(0.00)$ & 0.00 & $0.00(0.00)$ & $0.00(0.01)$ \\
\hline $\mathrm{BaO}$ & $0.00(0.04)$ & $0.00(0.06)$ & 0.08 & $0.01(0.02)$ & $0.12(0.09)$ \\
\hline $\mathrm{CaO}$ & $0.25(0.09)$ & $0.20(0.06)$ & 0.03 & $0.10(0.04)$ & $0.17(0.06)$ \\
\hline $\mathrm{Na}_{2} \mathrm{O}$ & $3.47(0.26)$ & $3.34(0.73)$ & 0.59 & $4.13(0.04)$ & $2.91(0.73)$ \\
\hline \multirow{2}{*}{$\begin{array}{r}\mathrm{K}_{2} 0 \\
\text { Total }\end{array}$} & $5.80(0.59)$ & $4.98(0.75)$ & 0.10 & $10.61(0.23)$ & $5.79(1.37)$ \\
\hline & 94.49 & 100.45 & 98.02 & 98.64 & 98.93 \\
\hline $\mathrm{Qz}$ & 32.35 & 40.37 & & 3.63 & 36.81 \\
\hline $0 r$ & 37.48 & 30.04 & & 63.42 & 35.63 \\
\hline$A b$ & 30.17 & 29.59 & & 32.95 & 27.22 \\
\hline \multirow[t]{2}{*}{ An } & 0.00 & 0.00 & & 0.00 & 0.33 \\
\hline & $\mathrm{Cr}+\mathrm{KAF}$ & $\mathrm{Cr}+\mathrm{KAF}$ & $\mathrm{Cr}$ & KAF & $\mathrm{Cr}+\mathrm{KAF}$ \\
\hline
\end{tabular}


YM-18 (254.8): Devitrified densely welded vitric tuff. Mast of this tuff consists of fine (3-10 $\mu \mathrm{m}$ diam) colorless phases replacing shards. Zoned lenticular vugs replace coarser shards; these are outlined by fibrous phases with tabular, euhedral, colorless phases growing into and somet imes filling the centers.

Relict punice pyroclasts are replaced by three phases. The first is an indistinct $r$ in of fibrous to granular, <3 un diameter phases. Voids are lined or filled with euhedral, tabular, colorless phases. Coarse fibrous to spherulitc phases orcur between rims and cores.

Phenocrysts include rounded plagioclase $\left(A n_{13-39}\right)$, subhedral sanidine $\left(0 r_{54-56}\right)$, and oxidized biotite and pyroxene (?). Rounded glomerocrysts of feldspar, biotite and quartz are al so present. Lithic fragnents consist of welded tuffs. En echelon to branching fractures $10-20 \mu \mathrm{m}$ tide are filled with quart 2 and parallel the rock fabric.

MODE

Phase

Shards ${ }^{d}$ and matrix

Pumice rims ${ }^{b, c}$ and coarse yug fill ${ }^{d, e, f}$

Phenocrysts

Sanidine

Plagioclase

Opaques

Lithic fragments

Fracture filling ${ }^{g}$

Total

\section{ANALYSES}

Dxide

$\mathrm{SiO}_{2}$
$\mathrm{Al}_{2} \mathrm{O}_{3}$

$\mathrm{Al}_{2} \mathrm{O}_{3}$
$\mathrm{BaO}$

$\mathrm{CaO}$

$\mathrm{Na}_{2} \mathrm{O}$

$\mathrm{k}_{2} \mathrm{O}$

Total

$\begin{array}{cc}\text { Qz } & 37.54 \\ \text { Or } & 31.46 \\ \text { Ab } & 30.24 \\ \text { An } & 0.76 \\ & \text { Cr+KAF }\end{array}$

Volume Percent

86.5

10.4

0.4

1.2

tr

0.8

0.8

100.1

$\begin{array}{ccccccc}\mathrm{a} & \mathrm{b} & c & \mathrm{~d} & \mathrm{e} & f & 9 \\ (12) & (7) & (6) & (7) & \langle 3) & \langle 5\} & \langle 1\rangle \\ 78.28(0.52) & 94.34(1.29) & 71.66(4.78) & 100.90(0.21) & 68.05(0.20) & 68.98(0.63) & 37.88 \\ 11.18(0.27) & 0.45(0.13) & 15.29(2.77) & 0.14(0.04) & 20.93(0.31) & 18.20\{0.68) & 0.29 \\ 0.04(0.02) & 0.04(0.01) & 0.06(0.01) & 0.00(0.00) & 0.01(0.01) & 0.00(0.00) & 0.17 \\ 0.34(0.07) & 0.02(0.02) & 0.77(0.48) & 0.00(0.00) & 2.42(0.14) & 0.34(0.12) & 0.05 \\ 3.25(0.18) & 0.16(0.07) & 5.09(0.96) & 0.05(0.00) & 9.79(0.18) & 5.17(0.40) & 0.03 \\ 5.14(0.16) & 0.06(0.03) & 5.42(3.82) & 0.01(0.01) & 1.29(0.33) & 8.96(0.48) & 0.00 \\ 98.23 & 95.03 & 98.29 & 101.10 & 102.49 & 101.65 & 98.42\end{array}$

\begin{tabular}{|c|c|c|c|c|}
\hline & 18.57 & & 1.35 & 3.82 \\
\hline & 32.35 & & 7.17 & 51.24 \\
\hline & 46.18 & & 82.68 & 44.93 \\
\hline & 2.89 & & 8.80 & 0.00 \\
\hline $\mathrm{Cr}$ & $C r+K A F$ & $\mathrm{Cr} / \mathrm{Qz}$ & NaAF & KAF \\
\hline
\end{tabular}


YM-22 (258.5): Devitrified densely welded vitric tuff. This rock consists of relict pumices in a matrix of small shards and vargs (5-20 $\mu \mathrm{m}$ long) filled with finely crystalline, pale brom to colorless phases. Coarser shards and pumice pyroclasts are zoned, ranging from $10 \mathrm{um}$ diameter, colorless phases along rims to $300 \mu \mathrm{m}$ diameter phases in the centers.

Rare phenocrysts include equant, slightly rounded plagioclase (An $14-16$ ), anipnibole(?) and biotite(?) replaced by hernatite, alkali feldspar, and magnetite. Lithic fragments cc'sist of rounded vitric tuff clasts. The rock is crossed by en echelon, 20-150 um wide fractures, wich are filled with quartz and parallel the fabric.

\begin{tabular}{|c|c|c|c|c|c|c|}
\hline \multicolumn{7}{|l|}{ MODE } \\
\hline \multicolumn{2}{|l|}{ Phase } & \multicolumn{5}{|l|}{ Volume Percent } \\
\hline \multicolumn{2}{|l|}{ Patrixa } & \multicolumn{5}{|l|}{59.2} \\
\hline \multicolumn{2}{|l|}{ Snards ${ }^{b}$} & \multicolumn{2}{|l|}{23.7} & & & \\
\hline \multicolumn{7}{|l|}{ Punice } \\
\hline \multicolumn{2}{|c|}{ Granular $r \mathrm{~m}^{\mathrm{C}}$} & \multicolumn{2}{|l|}{6.6} & & & \\
\hline \multicolumn{2}{|c|}{ Fibrous/spherulitic } & \multicolumn{2}{|l|}{4.6} & & & \\
\hline \multicolumn{2}{|c|}{ Coarse crystalline $d, e$} & \multicolumn{2}{|l|}{4.4} & & & \\
\hline \multicolumn{7}{|c|}{ Phenocrysts } \\
\hline \multicolumn{2}{|c|}{ Plagioclase } & \multicolumn{2}{|l|}{1.0} & & & \\
\hline \multicolumn{2}{|c|}{ Luthic fragmencs } & \multicolumn{2}{|l|}{0.4} & & & \\
\hline \multicolumn{2}{|c|}{ Fracture filling ${ }^{f}$} & \multicolumn{2}{|l|}{0.2} & & & \\
\hline \multicolumn{2}{|l|}{ To:al } & \multicolumn{2}{|l|}{100.1} & & & \\
\hline ANALYYSES & $a$ & b & c & a & e & $f$ \\
\hline Oxide & (3) & (3) & (2) & (4) & (2) & (2) \\
\hline $\mathrm{S}_{2} \mathrm{O}_{2}$ & $83.07(5.26)$ & $76.79(10.52)$ & $69.56(1.75)$ & $68.92(1.70)$ & $98.24(0.99)$ & $98.21(0.45)$ \\
\hline $\mathrm{Al}_{2} \mathrm{O}_{3}$ & $8.98(3.37)$ & $11.94(4.98)$ & $17.04(0.96)$ & $17.11(1.20)$ & $0.27(0.15)$ & $0.25(0.02)$ \\
\hline $\mathrm{FeO}^{2}$ & $0.18(0.05)$ & $0.14(0.12)$ & $0.08(0.01)$ & $0.07(0.04)$ & $0.01(0.01)$ & $0.02(0.00)$ \\
\hline $\mathrm{MgO}$ & $0.02(0.04)$ & $0.00(0.00)$ & $0.00(0.02)$ & $0.00(0.00)$ & $0.00(0.00)$ & $0.00(0.00)$ \\
\hline $\mathrm{BaO}$ & $0.00(0.00)$ & $0.03(0.03)$ & $0.00(0.06)$ & $0.01(0.03)$ & $0.00(0.00)$ & $0.01(0.01)$ \\
\hline $\mathrm{CaO}$ & $0.11(0.05)$ & $0.17(0.16)$ & $0.65(0.44)$ & $0.44(0.46)$ & $0.01(0.01)$ & $0.00(0.02)$ \\
\hline $\mathrm{N}_{2}{ }_{2} \mathrm{O}$ & $2.30(1.15)$ & $3.42(2.09)$ & $5.38(1.88)$ & $4.88(1.58)$ & $0.01(0.02)$ & $0.01(0.01)$ \\
\hline $\mathrm{K}_{2} \mathrm{O}$ & $4.99(1.94)$ & $6.17(4.24)$ & $6.54(1.84)$ & $7.27(1.56)$ & $0.02(0.03)$ & $0.02(0.02)$ \\
\hline Total & 99.65 & $98.60 \hat{~}$ & 99.26 & 98.70 & 98.56 & 98.52 \\
\hline $\mathrm{Qz}$ & 49.03 & 32.61 & 10.85 & 10.86 & & \\
\hline Or & 30.66 & 37.69 & 38.29 & 43.03 & & \\
\hline$A D$ & 20.31 & 29.70 & 47.87 & 43.91 & & \\
\hline An & 0.00 & 0.00 & 3.01 & 2.20 & & \\
\hline & $\mathrm{QZ}+\mathrm{KAF}$ & $Q 2+K A F$ & $K A F+Q 2$ & $K A F+Q 2$ & Qz & Qz \\
\hline
\end{tabular}


M-19 (267.9): Devitrified densely welded vitric tuff. This tuff consists of three major, gradational phastes. The most comon is a slightiy elongated (2-6 um long), fine-grained colorless phase. finely disseninated through this phase are very fine grained ( $<0.5 \mu \mathrm{m}$ diam) henatite grains. Spherulitic patches $300-600$ um wide are scattered throughout. At contacts between these two phases are coarser (up to 2 um wide and 10 um long) hematite grains.

Lenticular vugs, 100-0 $\mathrm{mm}$ long, are filled with sub- to euhedral, equant to tabular, colorless phases.

Rare phenocrysts consist of sanidine $\left(0 \mathrm{r}_{58}\right)$, subhedral plagioclase (An $\left.16-23\right)$ up to $100 \mathrm{um}$ long, quartz, and biotite replaced by henatite. Rare lithic fragments include devitrified rhyolitic lava clasts.

\section{MOOE}

Phase

Shards and matrix

Pumice (including rims) ${ }^{\text {b.c }}$

Phenocrysts

Sanidine

Opaques

Plagioclase

Fracture filling

Total

\section{ANAL YSES}

Ox ide

$\mathrm{SiO}_{2}$

Al $2 \mathrm{O}_{3}$

$\mathrm{FeO}$

$\mathrm{Hg} 0$

$\mathrm{BaO}$

$\mathrm{CaO}$

$\mathrm{Na}_{2} \mathrm{O}$
$\mathrm{K}_{2} \mathrm{O}$

Total

Qz

Or

$A b$

An

(14)

$6.16(0.57)$

98.44

30.52

37.64

31.01

0.84
Volume Percent

$$
72.2
$$

24.9
1.2
0.9
0.6
0.3

100.0

\section{b}

(2)

$95.41(0.32)$

$0.23(0.12)$

$0.04(0.04)$

$0.00(0.00)$

$0.00(0.00)$

$0.00(0.00)$

$0.00(0.00)$

$0.00(0.00)$

95. $6 \mathrm{~B}$

Qz+KAF

32.79
34.24
31.53
$\mathrm{Cr} / \mathrm{Qz} \quad \mathrm{1.40}$
$\mathrm{Qz}+\mathrm{KAF}$

d

(1)

$76.26(2.89) \quad 97.86$

$12.13(1.93) \quad 0.38$

$0.70(0.77) \quad 0.01$

$0.00(0.00) \quad 0.00$

$0.00(0.00) \quad 0.00$

$0.27(0.15) \quad 0.00$

$3.38(0.63) \quad 0.12$

$5.58(1.31) \quad 0.03$

$98.32 \quad 98.39$

32.79

34.24

Z+KAF

Qz 
YM-23 (272.5): Devitrified densely welded vitric tuff. Most of this rock consists of a matrix of relict shards, 1550 um long, with fine ( $5 \mu \mathrm{m}$ diam) granular, colorless phases occurring interstitially. Zoned vugs replace the coarser shards; rims consist of fibrous, $<5 \mu \mathrm{m}$ wide, $20-30 \mu \mathrm{m}$ long phases and centers are filled with colorless, sub- to eunedral blacky phases up to $100 \mu \mathrm{m}$ in diameter. Pumice pyroclasts are replaced by the same phases as in the 20 ned vugs, but the zonation is less well defined.

Fractured or rounded sanidine $\left(0 r_{55}\right)$ is the most abundant of the rare phenocrysts; magnetite, plagioclase, quartz, and biotite also occur. Lithic fragments consist of older welded tuffs. Occasional fractures are filled with quartz.

MODE

Phase

Small shards and matrix :

fibrous and granular ${ }^{b, c}$

Coarse shards

Pumice: fibrous ${ }^{e}$ and

coarse crystallined

Phenocrysts

Plagioclase and sanidine 0.6

Opaques

Fracture filling ${ }^{f}$

other

Total

\section{ANALYSES}

Oxide

$\mathrm{SiO}_{2}$

A) ${ }_{2} \mathrm{O}_{3}$

$\mathrm{FeO}$

$\mathrm{MgO}$

$\mathrm{BaO}$

$\mathrm{CaO}$

$\mathrm{Na}_{2} \mathrm{O}$

$\mathrm{K}_{2} \mathrm{O}$

Total

Q2 $\quad 36.72$

Or $\quad 37.18$

$\mathrm{Ab} \quad 26.10$

An

\section{b}

(1)

(3)

$77.19(0.46)$

$10.98(0.26)$

$0.54(0.29)$

$0.00(0.00)$

$0.00(0.05)$

$0.16(0.07)$

2. $95(0.50)$

$5.96(0.99)$

97.78

26.10

$Q_{2}+\mathrm{KAF}$

0.00

0.12

0.03

98.34

$\mathrm{QziCr}$
Volume Percent

54.5

15.9

27.2

0.2

0.2

1.4

100.0
97.72

0.40

0.00

0.00

0.02

10.63
100.37

(1)

67.90

17.94

0.10

0.00

0.00

0.07

3.73

10.63

100.3

$\begin{array}{rr}4.83 & 7.77 \\ 61.85 & 54.60 \\ 32.98 & 37.58 \\ 0.34 & 0.05 \\ \text { KAF } & \text { KAF }\end{array}$

\begin{abstract}
d
\end{abstract}
(2)

$69.06(0.18)$

$17.05(0.55)$

$0.23(0.19)$

$0.00(0.00)$

$0.05(0.08)$

$0.15(0.02)$

$4.22(0.00)$

$9.32(0.65)$

100.09

7.77

60

.05

KAF
(2)

(1)

$81.37(1.44) \quad 96.82$

$10.04(0.84) \quad 0.34$

$0.28(0.14) \quad 0.00$

$0.00(0.02) \quad 0.00$

$0.06(0.05) \quad 0.14$

$0.17(0.01) \quad 0.00$

$2.66(0.22) \quad 0.11$

$5.05(1.13) \quad 0.02$

$99.62 \quad 97.44$

43. 99

30.80

24.65

0.55

$\mathrm{Qz}+\mathrm{KAF} \quad \mathrm{Qz} / \mathrm{Cr}$ 
MM-24 (285.7): Devitrified densely welded vitric tuff. This tuff consists mostily of compacted relict shards up to 1 m long. These are crossed by $1-2 \mathrm{~cm}$ dianeter, coarsely crystalline spherulites; several of these originate in pumice pyroclasts but may extend beyond them. The matrix consisis of pale brom to colorless granular phases 5-15 um in diameter with finely dispersed sub-um hematite grains.

Relict pumices are zoned; fibrous rims grade into blocky, colorless phases in the interiors.

Trace phenocrysts include sanidine $\left(\mathrm{Or}_{63}\right)$, plagioclase $\left(\mathrm{An}_{16-34}\right)$, oxidized hornblende and biotite, magnetite, and glomerocrysts of plagiclase and hornblende. Lithic fragments include subangular chert clasts up to

$1 \mathrm{~mm}$ long and rounded welded tuff clasts. En echelon fractures 15-150 um wide parallel to the rock fabric are filled with quartz.

\section{MODE}

Phase

Shards and matrix

Punice ${ }^{b, c}$

Spherulitic patches ${ }^{d}$

Phenocrysts

Plagioclase and

sanidine

Biotite

Hornblende

Lithic fragments

Fracture fillinge

Total

\section{AMALYSES}

Oxide

$\mathrm{SiO}_{2}$

$\mathrm{Al}_{2} \mathrm{O}_{3}$

$\mathrm{FeO}$

$\mathrm{MgO}$

BaO

$\mathrm{CaO}$

$\mathrm{Na}_{2} \mathrm{O}$

$\mathrm{k}_{2} \mathrm{O}$

Total

\section{Qz}

Or

AD

An
Volume Percent

30.00

11.3

50.0

tr

tr

tr

8.0

0.7

100.0

\begin{tabular}{|c|c|c|c|c|}
\hline$a$ & b & C & d & e \\
\hline (4) & (4) & (3) & $(2)$ & (3) \\
\hline $80.18(3.43)$ & $99.40(0.83)$ & $67.83(0.08)$ & $74.74(0.19)$ & $95.82(1.50)$ \\
\hline $11.69(1.93)$ & $0.41(0.08)$ & $18.63(0.25)$ & $14.61(0.45)$ & $1.18(0.60)$ \\
\hline $0.31(0.36)$ & $0.07(0 . \mathrm{C4})$ & $0.14(0.05)$ & $0.19(0.10)$ & $0.00(0.02)$ \\
\hline $0.20(0.00)$ & $0.00(0.00)$ & $0.00(0.00)$ & $0.00(0.00)$ & $0.00(0.00)$ \\
\hline $0.00(0.00)$ & $0.05(0.09)$ & $0.06(0.10)$ & $0.19(0.12)$ & $0.13(0.07)$ \\
\hline $0.17(0.14)$ & $0.01(0.01)$ & $0.15(0.06)$ & $0.12(0.06)$ & $0.03(0.04)$ \\
\hline $3.10(0.92)$ & $0.12(0.11)$ & $4.61(0.27)$ & $3.75(0.54)$ & $0.42(0.33)$ \\
\hline $5.96(0.84)$ & $0.03(0.01)$ & $10.50(0.41)$ & $7.96(0.18)$ & $0.09(0.09)$ \\
\hline 101.40 & 100.09 & 101.92 & 101.56 & 97.68 \\
\hline 36.18 & & 1.32 & 20.81 & \\
\hline 35.42 & & 60.20 & 46.70 & \\
\hline 28.00 & & 38.48 & 32.50 & \\
\hline 0.38 & & 0.00 & 0.00 & \\
\hline $\mathrm{QZ}+\mathrm{KAF}$ & $\mathrm{Qz} / \mathrm{Cr}$ & $\mathrm{KAF}$ & $Q Z+A F$ & $Q z$ \\
\hline
\end{tabular}


M-25 (308.4): Devitrified densely welded vitric tuff. This rock is nearly identical to M-24, with the exception of more abundant spherulites in both the matrix and punice pyroclasts. Spherulitic zones cut cross-fabric, and are not limited to single pyroclasts. Rare phenocrysts include oxidized hornblende and biotite, quartz, and plagioclase $($ An $12-47)$. Thin fractures are filled with quartz.

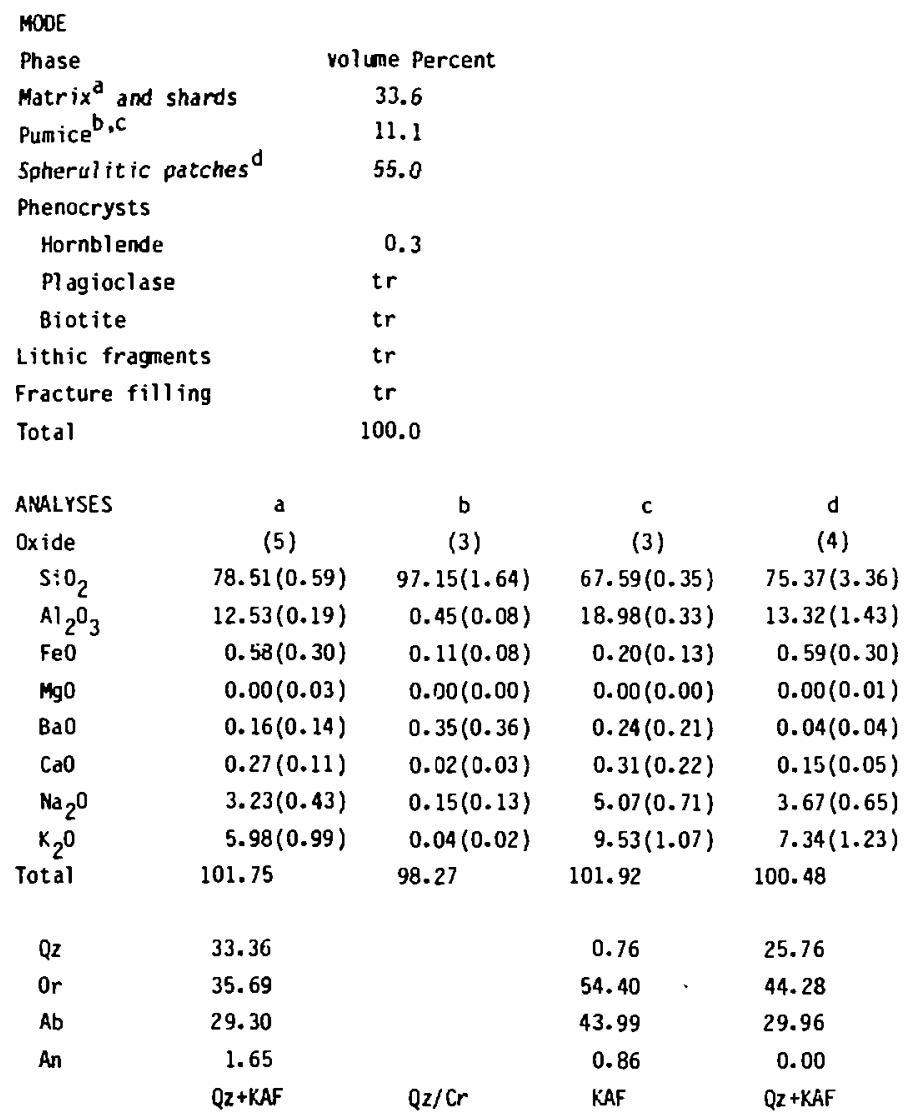




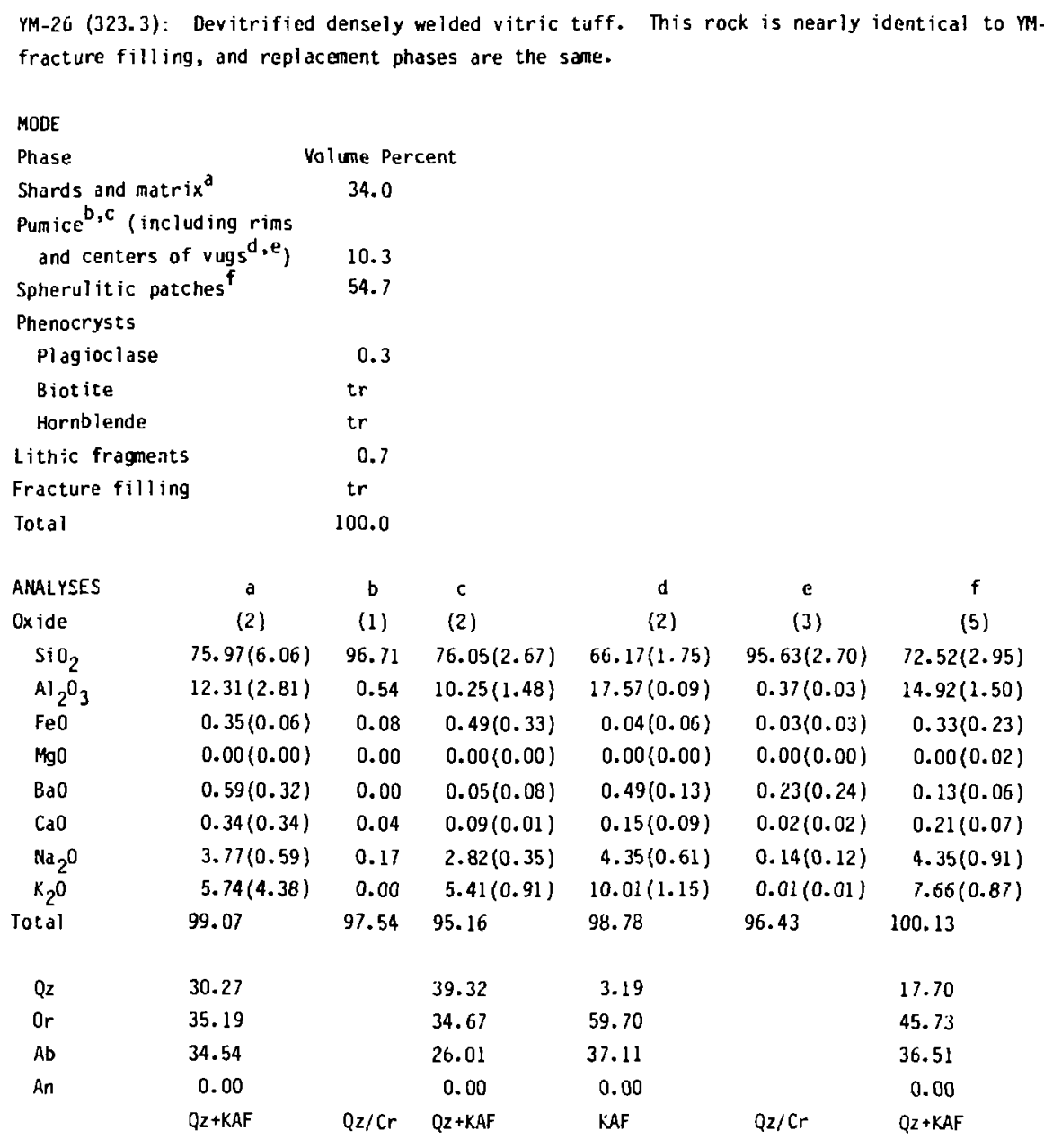


MM-27 (339.1): Devitrified densely welded vitric tuff. This rock is nearly identical to Samples MM-24 through M-26. in both texture and authigenic phase assemblage. Phenocrysts are limited to plagioclase $\left(A n_{31}\right)$, alkali feldspar, and quartz. 200-250 $\mu \mathrm{m}$ wide en echelon fractures parallel to the rock fabric are filled with quartz.

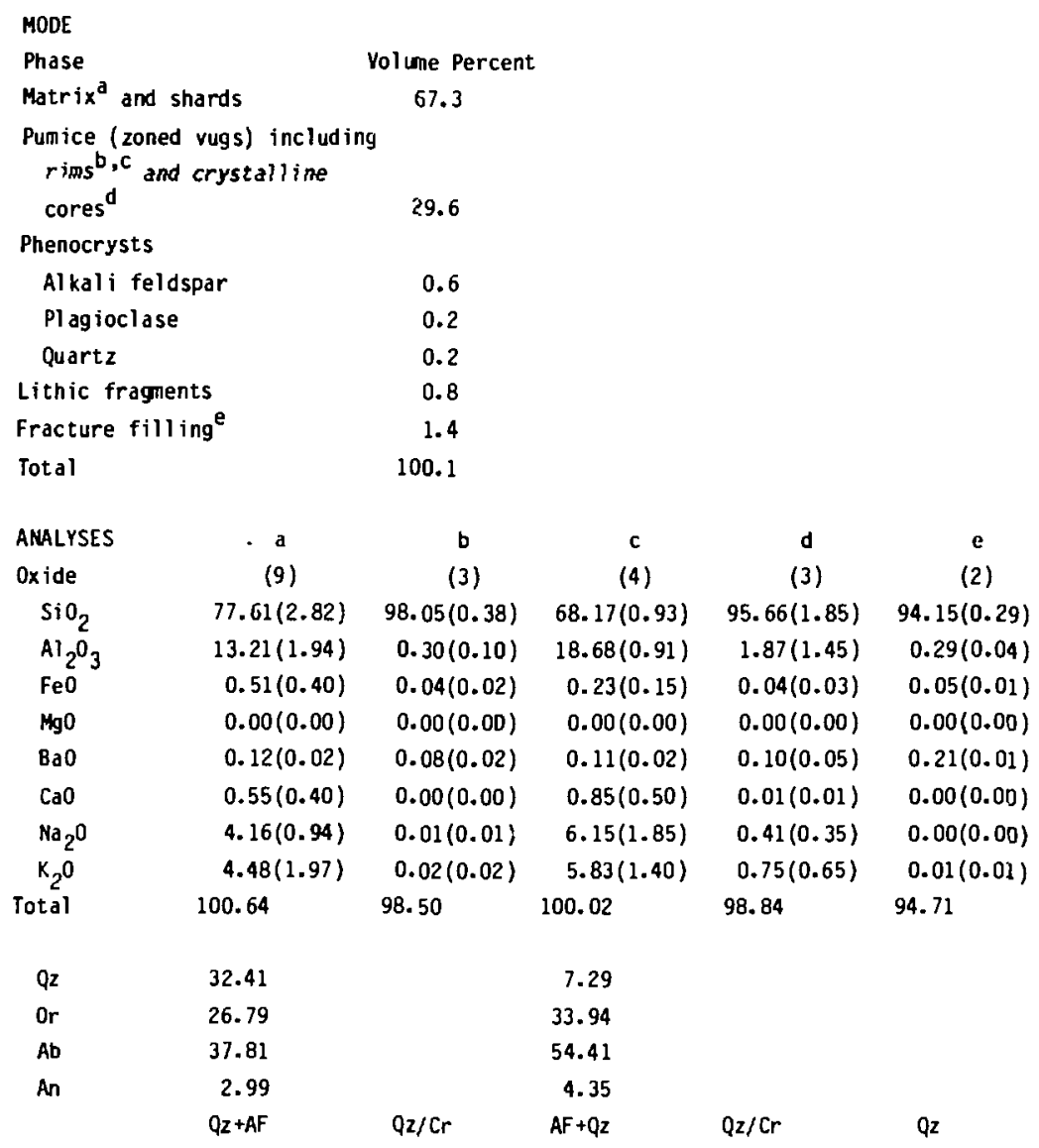


YM-2B (351.3): Devitrified densely welded vitric tuff. This rock is similar in many respects to MM-26 and MM-27, but contains much more of the evenly disnersed hematite. Hematite occurs as solid strands outlining relict pyroclasts, as finely crystalline $(<0.2 \mu m$ diam) grains dispersed throughout the rock, and as irregular patches 10 m in dianeter.

Phenocrysts include zoned plagioclase (An $30^{\text {core, }} 18^{\text {rim), }}$ quartz, sanidine (0r ${ }_{56}$ ) and magnetite. Fractures parallel to the fabric are about $10 \mu m$ wide and filled with quartz. Lithic fragments consist of devitrified rhyolitic lava clasts.

MODE

$\begin{array}{lc}\text { Phase } & \text { Volume Percent } \\ \text { Matrix and shards } & 62.2 \\ \text { Pumice (zaned vugs, including } & \\ \text { rims }{ }^{b}, c \text { and cores } & \text {,e,f) } \\ \text { Phenocrysts } & 26.5 \\ \quad \text { Plagioclase } & \\ \text { Sanidine } & 1.1 \\ \text { Quartz } & 0.4 \\ \text { Lithic fragnents } & 0.2 \\ \text { Fracture filling } & 6.1 \\ \text { Tatal } & 0.4\end{array}$


M-29 (364.3): Densely welded vitric tuff. This rock is similar mineralogically and texturally to YM-27 and Mm-28. . Spherulitic patches up to $4 \mathrm{~mm}$ in diameter consist of cores of tabular, colorless phases (up to 250 um long), rinmed with thin fibrous phases.

Phenocrysts include sanidine $\left(0 r_{59-62}\right)$, plagioclase ( $\left.A n_{18}\right)$, quartz, hornblende, and magnetite. Lithic fragments include subrounded tu subangular equant clasts of rhyolitic lava and welded tuff. En echelon fractures, parallel to the fabric, are filled with quartz.

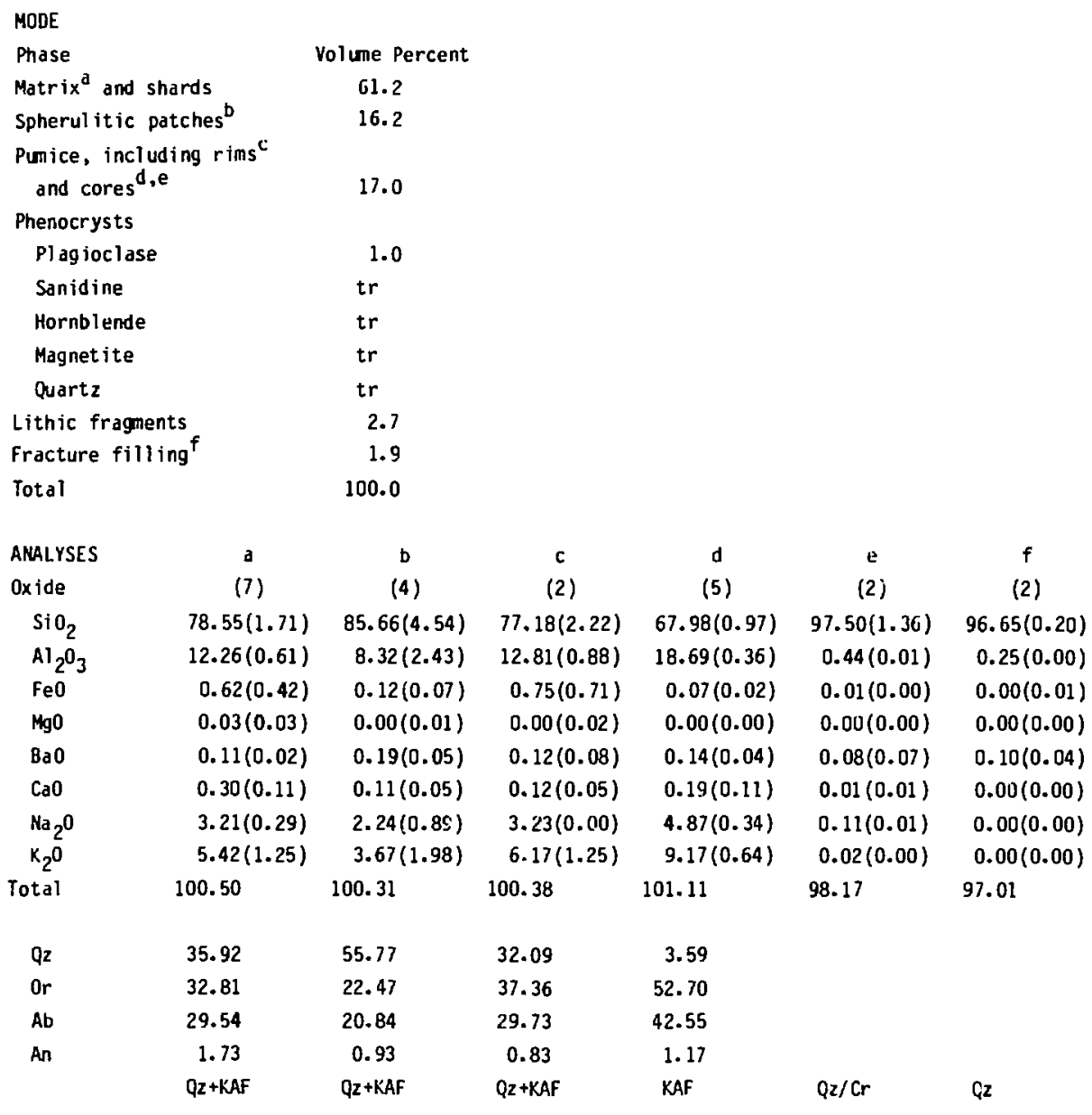


YM-30 (385.4): Devitrified densely welded vitric lithic tuff (vitrophyre). Densely welded and compacted shards with fibrous pale orange-brown cores and coloriess rims comprise most of this tuff. Pumice pyroclasts are replaced by fine ( $<2 \mu \mathrm{m}$ ) to medium (up to $200 \mu \mathrm{m}$ diam) colorless, equant to spherul itic phases.

Quartz, plagioclase $\left(\mathrm{An}_{31}\right\}$, sanidine $\left(\mathrm{Or}_{66}\right)$, and biotite are the phenocrysts. Abundant large (6-10 mm diam) 1 ithics consist of equant to slightly elongate fragments of devitrified welded tuff. Branching fractures $1-40$ mm wide are oriented nomal to the fabric and are filled with heulandite and montmorillonite.

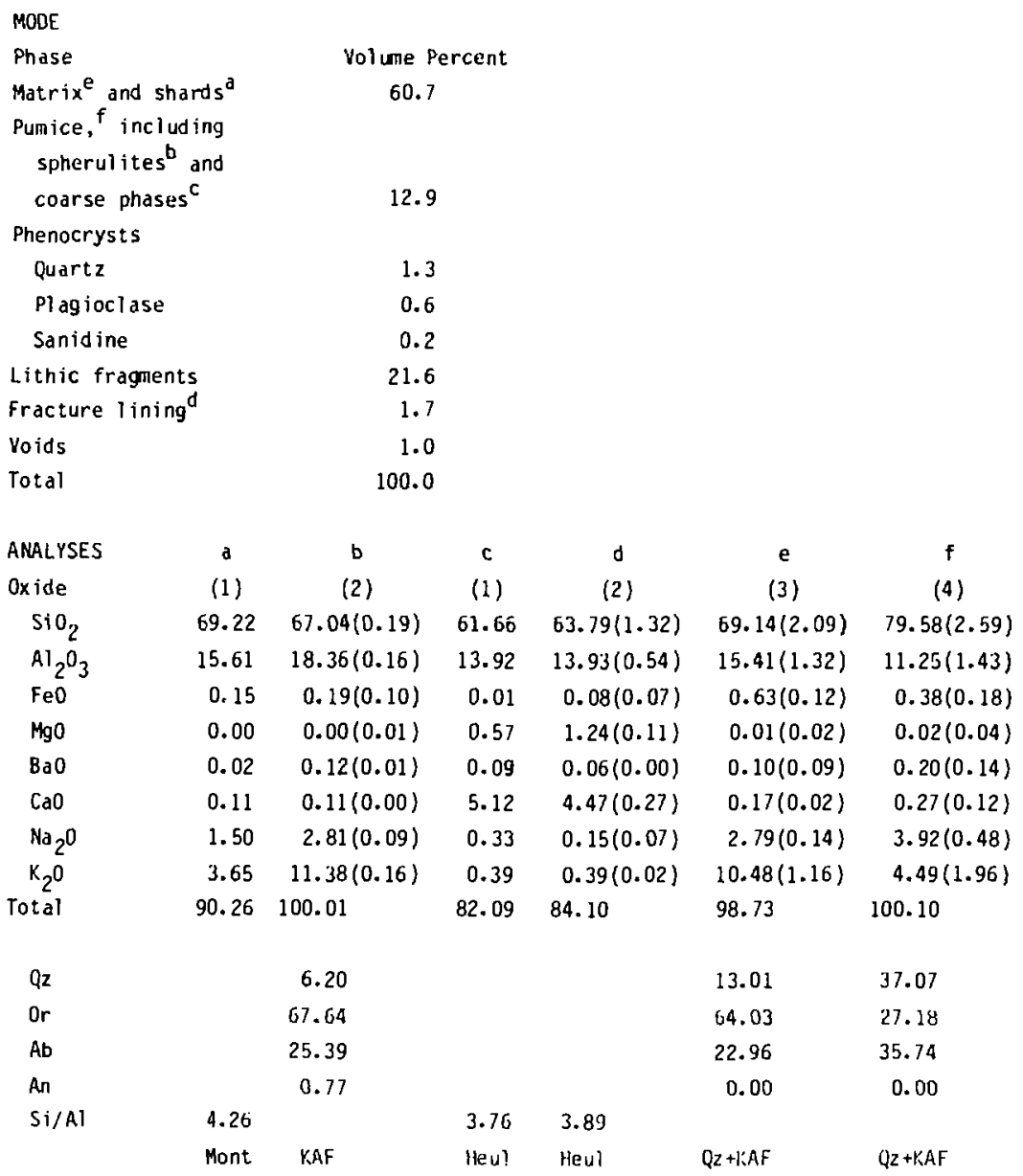


YM-31 (389.9): Densely welded Vitric tuff (vitropyre). Glassy shards, 150 um to 1 mm long, and flattened pumice pyroclasts up to $4 \mathrm{~cm}$ long, are crossed by perlitic cracks. A sub-um phase identified as heulandite lines the perlitic cracks; montmorillonite fills fractures that cut normal to the fabric.

Phenocrysts include zoned plagioclase up to $2 \mathrm{~mm} 10 \mathrm{gg}$, anorthoclase $\left(0 \mathrm{r}_{25}\right)$, quartz, biotite replaced by hematite, and magnetite(?).

\begin{tabular}{|c|c|c|c|}
\hline \multicolumn{4}{|l|}{ MOOE } \\
\hline Phase & \multicolumn{3}{|c|}{ Volune Percent } \\
\hline Shardsa & \multicolumn{3}{|c|}{59.0} \\
\hline Pumice ${ }^{c}$ & \multicolumn{3}{|c|}{31.3} \\
\hline \multicolumn{4}{|l|}{ Phenocrysts } \\
\hline Plagioclase & \multicolumn{3}{|c|}{0.3} \\
\hline Biotite & \multicolumn{3}{|c|}{0.3} \\
\hline Quartz & \multicolumn{3}{|c|}{$\operatorname{tr}$} \\
\hline Anorthocl ase & \multicolumn{3}{|c|}{$\mathrm{tr}$} \\
\hline Opaques & \multicolumn{3}{|c|}{$\operatorname{tr}$} \\
\hline Lithic fragment & \multicolumn{3}{|c|}{0.7} \\
\hline Perlitic crack & \multicolumn{3}{|l|}{ fill ing ${ }^{b}$} \\
\hline Total & \multicolumn{3}{|c|}{99.9} \\
\hline ANALYSES & $\mathbf{a}$ & b & c \\
\hline Oxide & (8) & (3) & (3) \\
\hline $\mathrm{SiO}_{2}$ & $74.38(0.25)$ & $55.67(0.10)$ & $77.57(0.55)$ \\
\hline $\mathrm{Al}_{2} \mathrm{O}_{3}$ & $11.43(0.15)$ & $14.08(1.10)$ & $12.03(0.12)$ \\
\hline $\mathrm{FeO}$ & $0.47(0.22)$ & $0.82(0.46)$ & $0.33(0.26)$ \\
\hline $\mathrm{Hg} 0$ & $0.00(0.01)$ & $3.30(0.55)$ & $0.00(0.03)$ \\
\hline BaO & $0.00(0.03)$ & $0.00(0.03)$ & $0.06(0.02)$ \\
\hline $\mathrm{CaO}$ & $0.38(0.03)$ & $2.10(0.03)$ & $0.43(0.13)$ \\
\hline $\mathrm{Na}_{2} \mathrm{O}$ & $3.69(0.11)$ & $0.62(0.24)$ & $2.42(0.09)$ \\
\hline $\mathrm{K}_{2} \mathrm{O}$ & $4.57(0.11)$ & $0.85(0.18)$ & $4.31(0.16)$ \\
\hline Total & 94.92 & 77.44 & 97.16 \\
\hline$Q z$ & 34.20 & & 46.16 \\
\hline $0 r$ & 29.00 & & 27.74 \\
\hline$A b$ & 35.59 & & 23.66 \\
\hline An & 1.21 & & 2.45 \\
\hline \multirow[t]{2}{*}{ Si/Al } & \multicolumn{3}{|c|}{3.35} \\
\hline & Glass & Heul & Gl ass \\
\hline
\end{tabular}


YM-32 (403.5): Altered nonwelded vitric-lithic tuff. This tuff consists of angular relict shards, 150 um to 1.5 long, and relict pumice pyroclasts up to $6 \mathrm{~mm}$ long, in a matrix of tan, finely crystalline phases. Shards are replaced

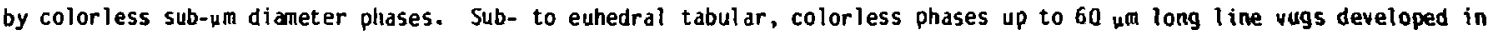
shards and vesicles in relict pumice pyroclasts. All of these authigenic phases are clinoptilolite.

Phenocrysts include alkali feldspar, plagioclase $\left(A_{15-22}\right)$, and quartz. Lithics include one 3.2 cm long rounded fragment of devitrified rhyolitic lava; other lithics are fragnents of welded tuffs.

\begin{tabular}{|c|c|c|c|c|}
\hline \multicolumn{5}{|l|}{ MODE } \\
\hline Phase & \multicolumn{3}{|c|}{ Volume Percent } & \\
\hline Shards ${ }^{a}$ & \multicolumn{2}{|r|}{25.3} & & \\
\hline Pumice $^{b}$ & \multicolumn{2}{|r|}{14.3} & & \\
\hline Matrix & \multicolumn{2}{|r|}{39.0} & & \\
\hline Vug fill in & \multicolumn{2}{|r|}{9.0} & & \\
\hline \multicolumn{5}{|c|}{ Phenocrysts } \\
\hline \multicolumn{2}{|c|}{ A]kali feldspar } & 3.3 & & \\
\hline \multicolumn{2}{|l|}{ Opaques } & 0.3 & & \\
\hline \multicolumn{2}{|c|}{ Plagioclase } & $\operatorname{tr}$ & & \\
\hline \multicolumn{2}{|c|}{ Quartz } & $\operatorname{tr}$ & & \\
\hline \multicolumn{2}{|c|}{ Lithic fragments } & 8.7 & & \\
\hline \multicolumn{2}{|l|}{ Total } & 99.9 & & \\
\hline ANALYSES & a & b & $c$ & d \\
\hline Oxide & (5) & (2) & (2) & (11) \\
\hline $\mathrm{SiO}_{2}$ & $66.20(1.21)$ & $67.63(0.26)$ & $65.40(1.98)$ & $66.46(1.49)$ \\
\hline $\mathrm{Al}_{2} \mathrm{O}_{3}$ & $10.86(0.18)$ & $11.07(0.17)$ & $11.90(0.49)$ & $11.25(0.18)$ \\
\hline $\mathrm{FeO}$ & $0.00(0.00)$ & $0.11(0.02)$ & $0.02(0.03)$ & $0.02(0.04)$ \\
\hline $\mathrm{MgO}$ & $0.47(0.11)$ & $0.44(0.01)$ & $0.55(0.11)$ & $0.51(0.09)$ \\
\hline $\mathrm{BaO}$ & $0.03(0.03)$ & $0.00(0.01)$ & $0.11(0.03)$ & $0.08(0.04)$ \\
\hline $\mathrm{CaO}$ & $3.58(0.28)$ & $3.41(0.02)$ & $3.37(0.14)$ & $3.62(0.25)$ \\
\hline $\mathrm{Na}_{2} \mathrm{O}$ & $0.44(0.06)$ & $0.72(0.04)$ & $0.37(0.03)$ & $0.48(0.20)$ \\
\hline $\mathrm{K}_{2} \mathrm{O}^{\mathrm{O}}$ & $1.55(0.08)$ & $1.63(0.00)$ & $1.59(0.05)$ & $1.40(0.20)$ \\
\hline Total & 83.13 & 85.00 & 83.31 & 83.82 \\
\hline \multirow[t]{2}{*}{ Si/Al } & 5.17 & 5.18 & 4.66 & 5.01 \\
\hline & $\mathrm{Cl}$ in & $\mathrm{Cl}$ in & $\mathrm{Cl}$ in & $\mathrm{Clin}$ \\
\hline
\end{tabular}


M-34 (413.9): Altered non- to slightly welded vitric tuff. This tuff consists mostly of relict pumice pyroclasts, 100 $\mu$ to $6 \mathrm{~m}$ long, in a matrix of 30-300 um long shards and pale brom finely crystalline coment (also fills voids and replaces the finer grained shards). Punice pyroclasts have been replaced by sub-um clinoptilalite grains. Vesicles are partly filled by euhedral, tabular clinoptilolite crystals up to $10 \mathrm{\mu m}$ long.

Phenocrysts include quartz and alkali feldspar. Lithic fragments are abundant; perlitic clasts (replaced by clinoptilolite) up to $3 \mathrm{~mm}$ in diameter are most comon. Other lithic clasis include siltstones and welded tuffs.

\begin{tabular}{|c|c|c|c|}
\hline \multicolumn{4}{|l|}{ MOOE } \\
\hline Phase & \multicolumn{3}{|c|}{ Volume Percent } \\
\hline Matrix & \multicolumn{3}{|c|}{42.7} \\
\hline Punice ${ }^{a}$ & \multicolumn{3}{|c|}{33.3} \\
\hline Shards & \multicolumn{3}{|c|}{10.0} \\
\hline Vug lining ${ }^{c}$ & \multicolumn{3}{|c|}{2.0} \\
\hline \multicolumn{4}{|l|}{ Phenocrysts } \\
\hline Quartz & \multicolumn{3}{|c|}{0.3} \\
\hline Alkalf felds & \multicolumn{3}{|c|}{$\operatorname{tr}$} \\
\hline Lithic fragnen & \multicolumn{3}{|c|}{8.3} \\
\hline Voids & \multicolumn{3}{|c|}{3.3} \\
\hline Total & \multicolumn{3}{|c|}{99.9} \\
\hline ANALYYSES & a & $b$ & c \\
\hline Oxide & (8) & (5) & (6) \\
\hline $\mathrm{SiO}_{2}$ & $67.69(073)$ & $63.80(3.12)$ & $66.67(0.58)$ \\
\hline $\mathrm{Al}_{2} \mathrm{O}_{3}$ & $11.23(0.40)$ & $10.25(0.76)$ & $11.21(0.73)$ \\
\hline $\mathrm{FeO}$ & $0.03(0.05)$ & $0.23(0.29)$ & $0.00(0.00)$ \\
\hline Mgo & $0.31(0.08)$ & $0.22(0.03)$ & $0.30(0.07)$ \\
\hline $\mathrm{BaO}$ & $0.07(0.03)$ & $0.03(0.03)$ & $0.10(0.06)$ \\
\hline $\mathrm{CaO}$ & $3.71(0.05)$ & $3.07(0.20)$ & $3.80(0.17)$ \\
\hline $\mathrm{Na}_{2} \mathrm{O}$ & $0.57(0.08)$ & $0.56(0.11)$ & $0.35(0.12)$ \\
\hline $\mathrm{K}_{2} \mathrm{O}$ & $1.79(0.21)$ & $2.05(0.79)$ & $1.78(0.08)$ \\
\hline Total & $85.40^{\circ}$ & 80.21 & 84.21 \\
\hline \multirow[t]{2}{*}{ Si $/ A 1$} & 5.11 & 5.28 & 5.05 \\
\hline & $\mathrm{Cl}$ in & $\mathrm{Clin}$ & Clin \\
\hline
\end{tabular}


MM-35 (421.1): Altered non-welded vitric tuff. This rock is identical texturally and mineralogically to M-34.

\begin{tabular}{|c|c|c|c|c|}
\hline \multicolumn{5}{|l|}{ MODE } \\
\hline Phase & \multicolumn{3}{|c|}{ Volume Percent } & \\
\hline Matrix & \multicolumn{3}{|c|}{43.7} & \\
\hline Shards ${ }^{b}$ & \multicolumn{3}{|c|}{3.3} & \\
\hline Punice ${ }^{c}$ & \multicolumn{3}{|c|}{31.3} & \\
\hline Vug linings & \multicolumn{3}{|c|}{7.0} & \\
\hline \multicolumn{5}{|l|}{ Phenocrysts } \\
\hline Plagioclase & \multicolumn{3}{|c|}{0.3} & \\
\hline Biotite & \multicolumn{3}{|c|}{0.3} & \\
\hline \multicolumn{4}{|l|}{ Sanidine and } & \\
\hline Lithic fragment & \multicolumn{3}{|c|}{8.7} & \\
\hline Voids & \multicolumn{3}{|c|}{5.3} & \\
\hline Total & \multicolumn{3}{|c|}{99.9} & \\
\hline AMLYSES & $\mathbf{a}$ & b & $c$ & d \\
\hline Oxide & (3) & (1) & (2) & (2) \\
\hline $\mathrm{SiO}_{2}$ & $67.08(1.48)$ & 65.46 & $67.18(0.86)$ & $66.02(0.12)$ \\
\hline $\mathrm{Al}_{2} \mathrm{O}_{3}$ & $9.34(0.11)$ & 10.61 & $10.51(0.50)$ & $10.90(0.17)$ \\
\hline $\mathrm{FeO}$ & $0.07(0.09)$ & 0.00 & $0.00(0.12)$ & $0.00(0.02)$ \\
\hline $\mathrm{MgO}$ & $0.00(0.03)$ & 0.45 & $0.00(0.04)$ & $0.31(0.21)$ \\
\hline $\mathrm{BaO}$ & $0.21(0.19)$ & 1.11 & $0.00(0.12)$ & $0.00(0.12)$ \\
\hline $\mathrm{CaO}$ & $2.86(0.11)$ & 3.57 & $2.82(0.09)$ & $3.44(0.22)$ \\
\hline $\mathrm{Ma}_{2} \mathrm{O}$ & $1.27(0.20)$ & 0.56 & $1.04(0.07)$ & $0.40(0.00)$ \\
\hline$k_{2} 0$ & $1.11(0.22)$ & 2.05 & $0.92(0.13)$ & $1.75(0.03)$ \\
\hline Total & 81.94 & 83.81 & 82.48 & 82.82 \\
\hline \multirow[t]{2}{*}{ Si/Al } & 6.09 & 5.23 & 5.42 & 5.14 \\
\hline & $\mathrm{Cl}$ in & Clin & Clin & Clin \\
\hline
\end{tabular}




\section{Bedded Iuffs of Calico Hjlls}

YM-36 (422.0): Altered nonwelded vitric tuff. This tuff consists of slightly ronded, non-vesicular, relict perlitic giass clasts and 2-5 m long punice pyroclasts. The fomer have been replaced by clinoptilolite.and are zoned parallel to the perlitic cracks. The perlitic cracks are filled with an unidentified orange-brown, sub- $\mu$ m phase. The two concentric zones parallel to the cracks are an outer zone of tan, finely crystalline clinoptilolite, grading into an inner zone of some coarsely crystalline tabular clinoptilolite crystals. Pumice pyroclasts have been replaced by colorless, finely crystalline clinoptilolite.

Phenocrysts in both perlite and pumice pyroclasts include plagioclase (An 12 ), quartz, sanidine (Or 67 ), and biotite. Lithics consist of devitrified banded rhyolitic lava fragments.

MODE

Phase

Punice

Perlitic clasts

Vug lining and coment ${ }^{b, c}$

Phenocrysts

Plagioclase

Quartz

Sanidine

Biotite

Lithic fragments

Voids

Total

\section{ANALYSES}

Qxide

$\mathrm{SiO}_{2}$

$\mathrm{Al}_{2} \mathrm{O}_{3}$

$\mathrm{FeO}$

MgO

$\mathrm{BaO}$

$\mathrm{CaO}$

$\mathrm{Na}_{2} \mathrm{O}$

$\mathrm{K}_{2} \mathrm{O}$

Total

Si/AI
Vol une Percent

$$
51.0
$$

18.0

24.0

1.7

0.7

0.3

$\mathrm{tr}$

1.7

2.7

100.1

(5) (7) (1)

$66.87(0.38) \quad 64.78(0.88) \quad 63.29$

$11.13(0.22) \quad 10.35(0.56) \quad 11.95$

$\begin{array}{llll}0.08(0.12) & 0.12(0.09) & 1.59\end{array}$

$0.38(0.02) \quad 0.44(0.05) \quad 0.00$

$\begin{array}{lll}0.00(0.00) & 0.00(0.08) & 0.00\end{array}$

$\begin{array}{lll}3.57(0.21) & 3.24(0.25) & 0.19\end{array}$

$\begin{array}{lll}0.57(0.24) & 0.82(0.40) & 4.80\end{array}$

$\begin{array}{lll}1.55(0.06) & 1.74(0.29) \quad 3.27\end{array}$

$\begin{array}{lll}84.15 & 81.49 & 85.09\end{array}$

$\begin{array}{lll}5.10 & 5.31 & 4.49 \\ \text { Clin } & C l i n & \end{array}$


M-37 (446.7): Altered slightly welded vitric tuff. This tuff consists of slightly compacted, 0.5 to 8 mo long relict punice pyroclasts. Glass has been replaced by a finely crystalline mixtue of authigenic quartz and zealite (heulandite/clinoptilolite). Vesicles and voids are partially to completely filled with tabular. 10-30 um long crystals of a zeolite (heulandite/clinoptilolite).

Phenocrysts include plagioclase $\left(A n_{15-24}\right)$, sanidine $\left(O r_{66}\right)$, quartz, and biotite; nearly all are fractured. Lithic fragments from $300 \mathrm{um}$ to $5 \mathrm{~mm}$ long consist of vitric and crystal-vitric welded tuff clasts.

\begin{tabular}{|c|c|c|c|}
\hline \multicolumn{4}{|l|}{ MODE } \\
\hline \multicolumn{2}{|l|}{ Phase } & \multicolumn{2}{|c|}{ Volume Percent } \\
\hline \multicolumn{2}{|c|}{ Matrix ${ }^{a, b}$} & \multicolumn{2}{|c|}{46.3} \\
\hline \multicolumn{4}{|c|}{ Pumice, including vug } \\
\hline \multicolumn{2}{|c|}{ lining and filling ${ }^{c}$} & 48.3 & \\
\hline \multicolumn{4}{|c|}{ Phenocrysts } \\
\hline \multicolumn{2}{|c|}{ Plagioclase } & 1.0 & \\
\hline \multicolumn{2}{|c|}{ Sanidine } & 1.0 & \\
\hline \multicolumn{2}{|c|}{ Lithic fragments } & 3.3 & \\
\hline \multicolumn{2}{|l|}{ Total } & \multicolumn{2}{|l|}{99.9} \\
\hline ANALYSES & a & b & $c$ \\
\hline Oxide & (3) & (1) & (10) \\
\hline $\mathrm{SiO}_{2}$ & $65.40(2.63)$ & 98.30 & $68.46(0.05)$ \\
\hline $\mathrm{Al}_{2} \mathrm{O}_{3}$ & $11.14(1.12)$ & 0.31 & $11.33(0.00)$ \\
\hline Fed & $0.37(0.37)$ & 0.00 & $0.01(0.00)$ \\
\hline $\mathrm{MgO}$ & $0.00(0.00)$ & 0.00 & $0.00(0.00)$ \\
\hline $\mathrm{BaO}$ & $0.04(0.04)$ & 0.00 & $0.01(0.00)$ \\
\hline $\mathrm{Ca} 0$ & $2.76(0.54)$ & 0.00 & $3.66(0.06)$ \\
\hline $\mathrm{Na}_{2} \mathrm{O}$ & $0.50(0.16)$ & 0.08 & $0.67(0.11)$ \\
\hline $\mathrm{K}_{2} \mathrm{O}$ & $4.05(3.59)$ & 0.30 & $2.14(0.14)$ \\
\hline Total & 84.26 & 98.99 & 86.28 \\
\hline \multirow[t]{2}{*}{ Si/Al } & 4.98 & & 5.13 \\
\hline & $\mathrm{Cl}$ in & $Q_{z}$ & Clin \\
\hline
\end{tabular}


M-38 (458.7): Altered nonwelded vitric tuff. This tuff is nearly identical to $M-37$ texturally and aineralogically.

\begin{tabular}{|c|c|c|c|c|}
\hline \multicolumn{5}{|l|}{ moOE } \\
\hline Phase & & Yolume Percent & & \\
\hline \multicolumn{5}{|c|}{ Perlitic clasts ${ }^{C}$ and } \\
\hline vog lin & & 24.0 & & \\
\hline Puniced & & 14.7 & & \\
\hline Matrix & & 46.7 & & \\
\hline \multicolumn{5}{|c|}{ Phenocrysts } \\
\hline Plagloc & & 1.0 & & \\
\hline Sanidin & & 1.0 & & \\
\hline Quartz & & 2.0 & & \\
\hline \multicolumn{2}{|c|}{ Lithic fragents } & 7.7 & & \\
\hline \multicolumn{2}{|c|}{ Yoids } & 1.0 & & \\
\hline \multicolumn{2}{|l|}{ Total } & 100.1 & & \\
\hline \multicolumn{2}{|l|}{ AMALYSES } & b & c & d \\
\hline Oxide & (5) & (3) & (4) & (3) \\
\hline \multirow{3}{*}{$\begin{array}{l}\mathrm{SiO}_{2} \\
\mathrm{Ai}_{2} \mathrm{O}_{3} \\
\mathrm{FeO}\end{array}$} & $65.13(5.50)$ & $65.86(0.55)$ & $65.55(0.91)$ & $70.88(5,01)$ \\
\hline & $12.57(0.17)$ & $9.95(0.81)$ & $11.41(0.29)$ & $10.25(0.92)$ \\
\hline & $0.01(0.03)$ & $0.01(0.03)$ & $0.04(0.13)$ & $0.01(0.02)$ \\
\hline$M 0$ & $0.00(0.00)$ & $0.00(0.01)$ & $0.00(0.00)$ & $0.00(0.01)$ \\
\hline BaO & $0.03(0.01)$ & $0.04(0.04)$ & $0.14(0.09)$ & $0.00(0.06)$ \\
\hline $\mathrm{CaO}$ & $3.71(0.13)$ & $3.33(0.22)$ & $3.46(0.09)$ & $3.02(0.55)$ \\
\hline $\mathrm{Ha}_{2} \mathrm{O}$ & $0.70(0.20)$ & $0.60(0.06)$ & $0.78(0.18)$ & $0.39(0.03)$ \\
\hline \multirow{2}{*}{$\begin{array}{r}\mathrm{K}_{2} \mathrm{O} \\
\text { Total }\end{array}$} & $2.60(0.47)$ & $2.25(0.24)$ & $3.07(0.45)$ & $2.10(0.48)$ \\
\hline & 84.75 & 82.05 & 84.46 & 86.65 \\
\hline \multirow[t]{2}{*}{$\mathrm{Si} / \mathrm{Al}$} & 4.39 & 5.61 & 4.87 & 5.87 \\
\hline & Clin & Clin & clin & $\mathrm{Cl}$ in \\
\hline
\end{tabular}


M-39 (482.9): Aitered nanwelded vitric tuff. This rack consists mostly of equant to slightly elongate, angular to subrounded perlite frayments. Most of these fragments have been replaced by micro- to medium crystalline clinoptilolite and are zaned as in YM.-36. Some fragments have 100-200 um diameter spherulites. There are also scane ragged relict pumice pyroclasts up to 5 min long. Cenent consists of a finely crystalline fibrous, highly birefringent, pale yellow-brom mineral (montmorillonite?).

Phenocrysts include sanidine $\left(0 \mathrm{r}_{70-72}\right)$, plagioclase, quartz, and biotite. A 2-m wide black band, consisting of an oxide wich is bright yellow in reflected light, crosses the sample. Perlitic cracks are lined with an orange-yellow, highly birefringent phase (montmorillonite?).

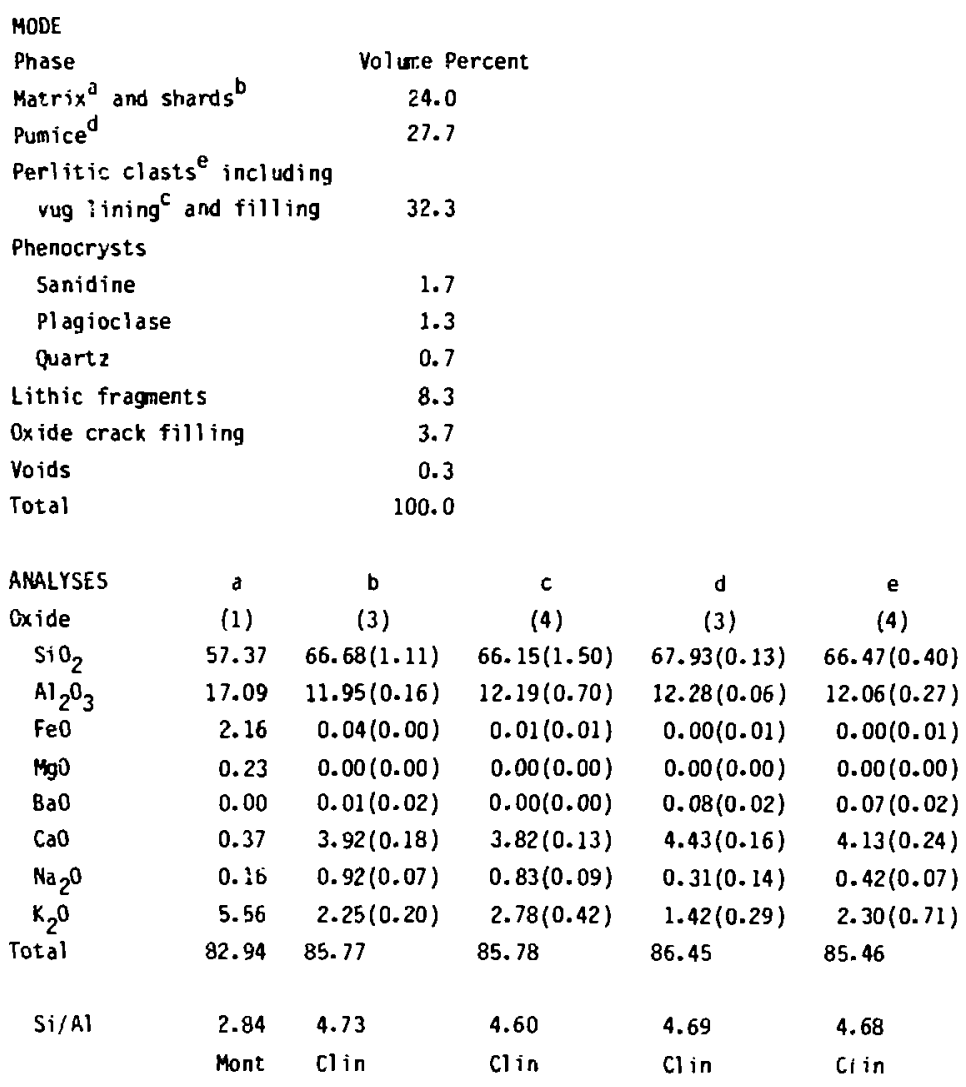


M-40 (508.1): Altered non-welded vitric tuff. Poorly preserved, angular relict pumice pyroclasts, $300 \mu \mathrm{m}$ to $4 \mathrm{~mm}$ long. are enclosed in a matrix of pale brom, <1-5 $\mu$ m diameter zeolite grains. Within the matrix only faint relict shard forms are preserved. Voids and vesicles are filled with euhedral tabular crystals of authigenic K-feldspar and quart $z$.

Phenocrysts include plagioclase $\left(A n_{13-17}\right)$, sanidine $\left(0 r_{48}\right)$, quartz, and magnetite. Lithic fragments consist of rounded clasts of weided tuff, $300{ }^{\text {min }}$ to $3.5 \mathrm{~mm}$ in diameter.

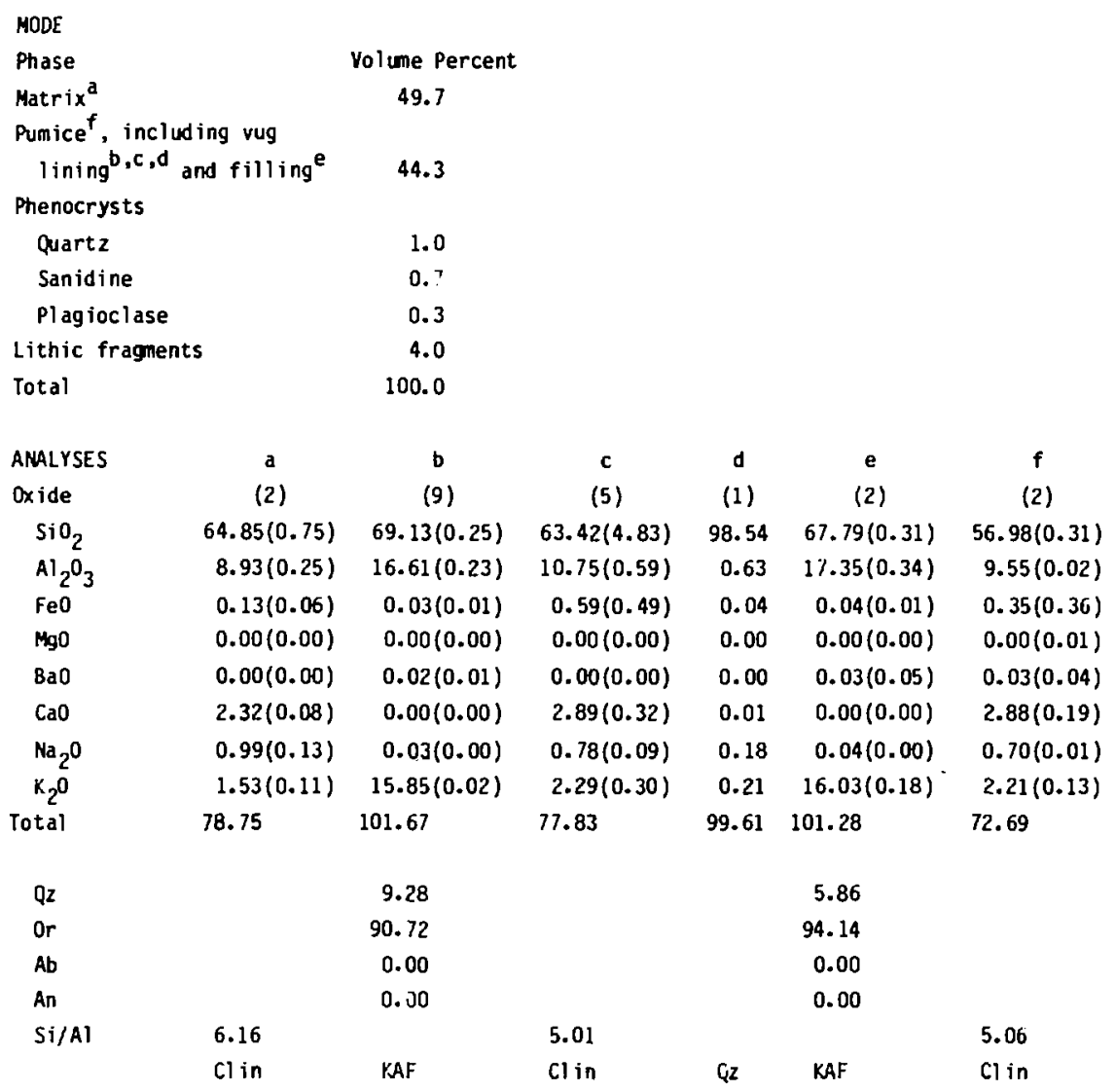


MM-41 (540.8): Devitrified (?) non-welded vitric tuff. Only a few faint relict pyroclasts can be seen in this highly altered tuff. Host of the rock consists of pale brown, finely crystalline, 1-4 um dianeter phases. These may be a mixture of authigenic feldspar, quartz, and zeolite (?). Poorly defined relict pumices range from 1 mim to several cm in length, and have been replaced by a mixture of alkali feldspar and quartz.

Phenorrysts include plagioclase (An $17-29$ ), alkali feldspar, and quartz. Abundant lithic fragments are all subrounded clasts of welded tuff.

\begin{tabular}{|c|c|c|c|c|}
\hline \multicolumn{5}{|l|}{ MODE } \\
\hline Phase & & Volume Percent & & \\
\hline Matrix ${ }^{a, d}$ & & 54.0 & & \\
\hline Pumice ${ }^{b}$ and vus & fill ing $c$ & 33.0 & & \\
\hline \multicolumn{5}{|l|}{ Phenocrysts } \\
\hline Plaoioclase & & 1.6 & & \\
\hline Alkal, feldsp & & 1.0 & & \\
\hline Quartz & & 1.0 & & \\
\hline Lithic fragment & & 4.9 & & \\
\hline Yoids & & 4.5 & & \\
\hline Total & & 100.0 & & \\
\hline ANALYSES & $a$ & $b$ & $c$ & d \\
\hline Dxide & (2) & (2) & (4) & (3) \\
\hline $\mathrm{SiO}_{2}$ & $65.15(0.78)$ & $87.81(4.33)$ & $66.81(0.39)$ & $70.00(2.92)$ \\
\hline $\mathrm{Al}_{2} \mathrm{O}_{3}$ & $8.37(0.16)$ & $6.27(1.76)$ & $15.40(0.37)$ & $11.56(1.94)$ \\
\hline $\mathrm{Fe} 0$ & $0.28(0.33)$ & $0.11(0.00\}$ & $0.21(0.10)$ & $0.49(0.14)$ \\
\hline $\mathrm{Mg} 0$ & $0.00(0.00)$ & $0.00(0.00)$ & $0.00(0.00)$ & $0.00(0.00)$ \\
\hline $\mathrm{BaO}$ & $0.00(0.00)$ & $0.03\langle 0.01\}$ & $0.00\langle 0.06\}$ & $0.10(0.06)$ \\
\hline $\mathrm{CaO}$ & $0.85(0.21)$ & $0.12(0.06)$ & $0.04(0.02)$ & $1.55(0.56)$ \\
\hline $\mathrm{Na}_{2} \mathrm{O}$ & $0.51(0.11)$ & $1.88(0.64)$ & $0.05\{0.01\}$ & $0.53(0.10)$ \\
\hline $\mathrm{K}_{2} \mathrm{O}$ & $5.99(3.69)$ & $3.43(0.69)$ & $15.47(0.50)$ & $4.24(2.16)$ \\
\hline TotaT & 81.15 & 99.65 & 98.00 & 88.47 \\
\hline Qz & & 63.79 & 11.07 & \\
\hline or & & 21.44 & 88.93 & \\
\hline$A b$ & & 14.77 & 0.00 & \\
\hline An & & 0.00 & 0.00 & \\
\hline \multirow[t]{2}{*}{$\mathrm{Si} / \mathrm{AT}$} & 6.60 & & & 5.14 \\
\hline & Cl in & $Q z+K A F$ & KAF & $\mathrm{Cl}$ in \\
\hline
\end{tabular}


M-42 (556.1): Coarse sandstone: clayey, very immature, feldspathic, volcanic litharenite. This rock is an alluvial' sandstone, consisting mostly of angular fragnents of devitrified or zeolitized welded tuff. Other grains include slightly rounded perlitic fragments, rhyolitic lavas, biotite, alkali feldspar, plagioclase, magnetite, and calcite pseudomorphing plagioclase. The matrix consists of heavily hematite-stained clay.

\begin{tabular}{|c|c|c|c|c|}
\hline \multicolumn{5}{|l|}{ MODE } \\
\hline Phase & & \multicolumn{3}{|l|}{ Volume Percent } \\
\hline Clay matrix & & \multicolumn{3}{|l|}{45.7} \\
\hline \multicolumn{5}{|l|}{ Lithic clasts } \\
\hline Perlite & \multicolumn{4}{|c|}{3.3} \\
\hline \multicolumn{5}{|c|}{ Altered welded tuff $a, b, c, d$} \\
\hline \multicolumn{5}{|c|}{ Rhyolite (?) lava } \\
\hline \multicolumn{5}{|l|}{ Crystal clasts } \\
\hline \multicolumn{5}{|l|}{ Plagioclase } \\
\hline \multicolumn{5}{|l|}{ Magnet ite } \\
\hline \multicolumn{5}{|l|}{ Quartz } \\
\hline \multicolumn{5}{|l|}{ Biotite } \\
\hline \multicolumn{5}{|c|}{ Alkali feldspar } \\
\hline \multicolumn{5}{|c|}{ Calcite fflling or replacement } \\
\hline \multicolumn{5}{|c|}{$9 y .9$} \\
\hline ANALYSES & $\mathbf{a}$ & b & c & d \\
\hline Oxide & (2) & (2) & (2) & (2) \\
\hline $\mathrm{SiO}_{2}$ & $63.46(2.19)$ & $63.00(0.11)$ & $66.53(0.17)$ & $67.41(1.63)$ \\
\hline $\mathrm{Al}_{2} \mathrm{O}_{3}$ & $19.96(1.55)$ & $13.94(0.07)$ & $12.94(0.07)$ & $13.42(0.39)$ \\
\hline $\mathrm{FeO}$ & $0.24(0.08)$ & $0.00(0.00)$ & $0.00(0.20)$ & $0.24(0.16)$ \\
\hline $\mathrm{MgO}$ & $0.00(0.01)$ & $0.15(0.00)$ & $0.08(0.03)$ & $0.18(0.06)$ \\
\hline $\mathrm{BaO}$ & $0.00(0.02)$ & $0.00(0.03)$ & $0.00(0.00)$ & $0.00(0.01)$ \\
\hline $\mathrm{CaO}$ & $2.38(2.06)$ & $5.71(0.09)$ & $5.02(0.07)$ & $4.64(0.46)$ \\
\hline $\mathrm{Na}_{2} \mathrm{O}$ & $3.60(1.83)$ & $0.22(0.02)$ & $0.21(0.02)$ & $0.30(0.01)$ \\
\hline $\mathrm{K}_{2} \mathrm{O}$ & $9.34(4.18)$ & $1.01(0.00)$ & $1.21(0.21)$ & $2.28(1.47)$ \\
\hline Total & $\begin{array}{l}98.99 \\
-\end{array}$ & 84.04 & 86.00 & 88.45 \\
\hline Qz & 1.49 & & & \\
\hline Or & 55.28 & & & \\
\hline$A b$ & 32.39 & & & \\
\hline An & 10.75 & & & \\
\hline$S i / A l$ & & 3.83 & 4.36 & 4.26 \\
\hline & KAF & Heul & Heul & Heul \\
\hline
\end{tabular}


YM-43 (564.5): Devitrified welded vitric-crystal tuff. This tuff consists of very poorly preserved relict pumice pyroclasts up to $350 \mathrm{um}$ long in a matrix of uniformly mixed finely crystalline (2-4 $\mathrm{\mu m}$ diam) colorless phases and coarser (60-90 $\mu \mathrm{m} \mathrm{diam),} \mathrm{equigranular,} \mathrm{colorless,} \mathrm{anhedral} \mathrm{phases.} \mathrm{Relict} \mathrm{pumice} \mathrm{pyroclasts} \mathrm{have} \mathrm{been} \mathrm{replaced} \mathrm{by} \mathrm{a} \mathrm{mixture} \mathrm{of}$ the fine grained phase described above and medium crystalline (up to $350 \mu \mathrm{m}$ long) subhedral phases.

Rounded sanidine $\left(0 r_{54}\right)$, magnetite, resorbed quartz, and oxidized biotite are the major phenocryst phases. Lithic fragments include sightly angular to rounded siltstone clasts, stained by hematite.

\begin{tabular}{|c|c|c|c|c|}
\hline \multicolumn{5}{|l|}{ MODE } \\
\hline Phase & & \multicolumn{3}{|c|}{ Volume Percent } \\
\hline Matrix ${ }^{a, b}$ & & 47.3 & & \\
\hline \multicolumn{5}{|l|}{ Pumice $c, d$} \\
\hline \multicolumn{2}{|c|}{ Medium crystalline } & 28.2 & & \\
\hline \multicolumn{2}{|c|}{ Coarse crystalline } & 14.4 & & \\
\hline \multicolumn{5}{|l|}{ Phenocrysts } \\
\hline \multicolumn{2}{|l|}{ Sanidine } & 7.7 & & \\
\hline \multicolumn{2}{|l|}{ Quartz } & 1.3 & & \\
\hline \multicolumn{2}{|l|}{ Biotite } & 0.3 & & \\
\hline \multicolumn{2}{|c|}{ Lithic fragments } & 0.7 & & \\
\hline \multicolumn{2}{|l|}{ Total } & 99.9 & & \\
\hline ANAL YSES & a & $b$ & c & $d$ \\
\hline Oxide & (3) & (1) & (4) & (4) \\
\hline $\mathrm{SiO}_{2}$ & $90.77(0.71)$ & 56.82 & $93.87(0.13)$ & $65.47(0.86)$ \\
\hline $\mathrm{Al}_{2} \mathrm{O}_{3}$ & $2.37(0.29)$ & 10.36 & $0.45(0.08)$ & $17.20(0.22)$ \\
\hline $\mathrm{Fe} 0$ & $0.11(0.15)$ & 2.45 & $0.00(0.00)$ & $0.12(0.03)$ \\
\hline $\mathrm{MgO}$ & $0.00(0.00)$ & 0.00 & $0.00(0.00)$ & $0.00(0.00)$ \\
\hline $\mathrm{BaO}$ & $0.00(0.02)$ & D. 04 & $0.00(0.00)$ & $0.01(0.02)$ \\
\hline $\mathrm{CaO}$ & $0.03(0.01)$ & 0.03 & $0.00(0.00)$ & $0.12(0.03)$ \\
\hline $\mathrm{Na}_{2} \mathrm{O}$ & $0.38(0.15)$ & 1.10 & $0.09(0.02)$ & $2.48(0.15)$ \\
\hline $\mathrm{K}_{2} \mathrm{O}$ & $1.41(0.22)$ & 9.94 & $0.11(0.05)$ & $11.47(0.38)$ \\
\hline Total & 95.06 & 80.73 & 94.52 & 96.87 \\
\hline$Q z$ & & & & 6.49 \\
\hline Or & & & & 69.90 \\
\hline$A b$ & & & & 22.98 \\
\hline An & & & & 0.63 \\
\hline $\mathrm{Si} / \mathrm{Al}$ & & 4.66 & & \\
\hline & Qz & Mont & $Q z$ & KAF \\
\hline
\end{tabular}


YM-44 (569.7): Devitrified welded vitric-crystal tuff. This tuff is similar texturally and mineralogically to YM-4J. Major differences are 1) fewer rolict pumice pyroclasts, and 2) more phenocrysts.

\section{MODE}

Phase

Matrix ${ }^{a, b}$

Pumice

Medium crystalline

Coarse crystalline ${ }^{c}$

Phenocrysts

Sanidine

Plagioclase

Biotite

Quartz

Total

ANALYSES

Oxide

$\mathrm{SiO}_{2}$

${ }^{A 1} 2_{3}{ }^{0}$

$\mathrm{FeO}$

$\mathrm{MgO}$

BaO

$\mathrm{Ca} 0$

$\mathrm{Na}_{2} \mathrm{O}$

$\mathrm{K}_{2} \mathrm{O}$

Total

-

Qz

or

$A b$

An

1.93
97.52

1.98

11.28

77.22

9.53
Volume Percent

53.3

22.7

13.7

5.3

4.3

0.7

tr

100.0 c

(3)

$95.84(0.45)$

$0.32(0.02)$

$0.04(0.04)$

$0.00(0.00)$

$0.00(0.03)$

$0.00(0.00)$

$0.09(0.00)$

$0.02(0.01)$

96.30

$0.15(0.11)$

$0.21(0.25)$

93.47

$\mathrm{NaAF}$

$n z$

Qz 
YM-45 (588.4): Devitrified elded vitric-crystal tuff. Poorly preserved relict pumice pyroclasts, 3-4 mm long with abundait voids are enclosed by very fine (1-2 um diam) to fine (10-25 $\mathrm{mm})$ granular to fibrous colorless phases. Pumice pyroclasts are replaced by a mixture of these fine grained phases, spherulites, and sub- to euhedral tabular, colorless crystals up to $100 \mu m$ long.

Phenocrysts include resorbed to euhedral plagioclase, sanidine $\left(0 r_{51-56}\right)$, and biotite. Rare lithic fragments consist of welded tuff clasts.

MODE

Phase

Matrix

Fibrous/granular

Coarse crystalline $e^{b, c}$

Pumice

Fibrous/spherul it ic

Coarse crystallined

Phenocrysts

Sanidine

Plagioclase

Biotite

Lithic fragments

Voids

Tot a 1

ANALYSES

Oxide

$\mathrm{SiO}_{2}$

$\mathrm{Al}_{2} \mathrm{O}_{3}$

$\mathrm{FeO}$

$\mathrm{MgO}$

800

$\mathrm{CaO}$

$\mathrm{Na}_{2} \mathrm{O}$

$\mathrm{K}_{2} \mathrm{O}$

Total

$Q 2$

Or

Ab

An

Si/A.I
Volume Percent

36.6

30.1

5.0

5.0

8.9

4.2

0.4

0.6

9.3

100.1

$\begin{array}{ccc}b & c & d \\ (2) & (1) & (3) \\ .29(1.12) & 63.09 & 94.38(1.00) \\ .38(0.08) & 22.84 & 0.40(0.05) \\ .03(0.01) & 0.08 & 0.00(0.02) \\ .00(0.00) & 0.00 & 0.00(0.08) \\ .01(0.01) & 0.21 & 0.00(0.03) \\ .00(0.00) & 4.61 & 0.00(0.01) \\ 11(0.01) & 8.41 & 0.14(0.04) \\ .05(0.01) & 0.71 & 0.10(0.13) \\ 87 & 100.14 & 95.03\end{array}$

1.34

4. 05

72.91

21.70

NaAF $\quad Q_{2}$ 
MM-46 (610.1): Devitrified densely welded vitric-crystal tuff. Numerous relict pumice pyraclasts are in a matrix of highly compacted relict shards and cement. Pumice pyroclasts have been replaced by $1 . \dot{5} \mathrm{~mm}$ diameter spherulites and by 2-5 $\mu \mathrm{m}$ long fibrous phases (mostly aikali feldspar). Shards are replaced by anhedral, calorless phases, 60 um long and $6 \mu \mathrm{m}$ wide. Abundant hemat ite occurs as disseminated $1-3 \mu \mathrm{m}$ diameter grains.

Phenocrysts include plagioclase $\left(\mathrm{An}_{8-9}\right)$, alkali feldspar, and resorbed quartz; most are fractured. A $3-5$ mm wide band of Mn-oxides crosses this sample.

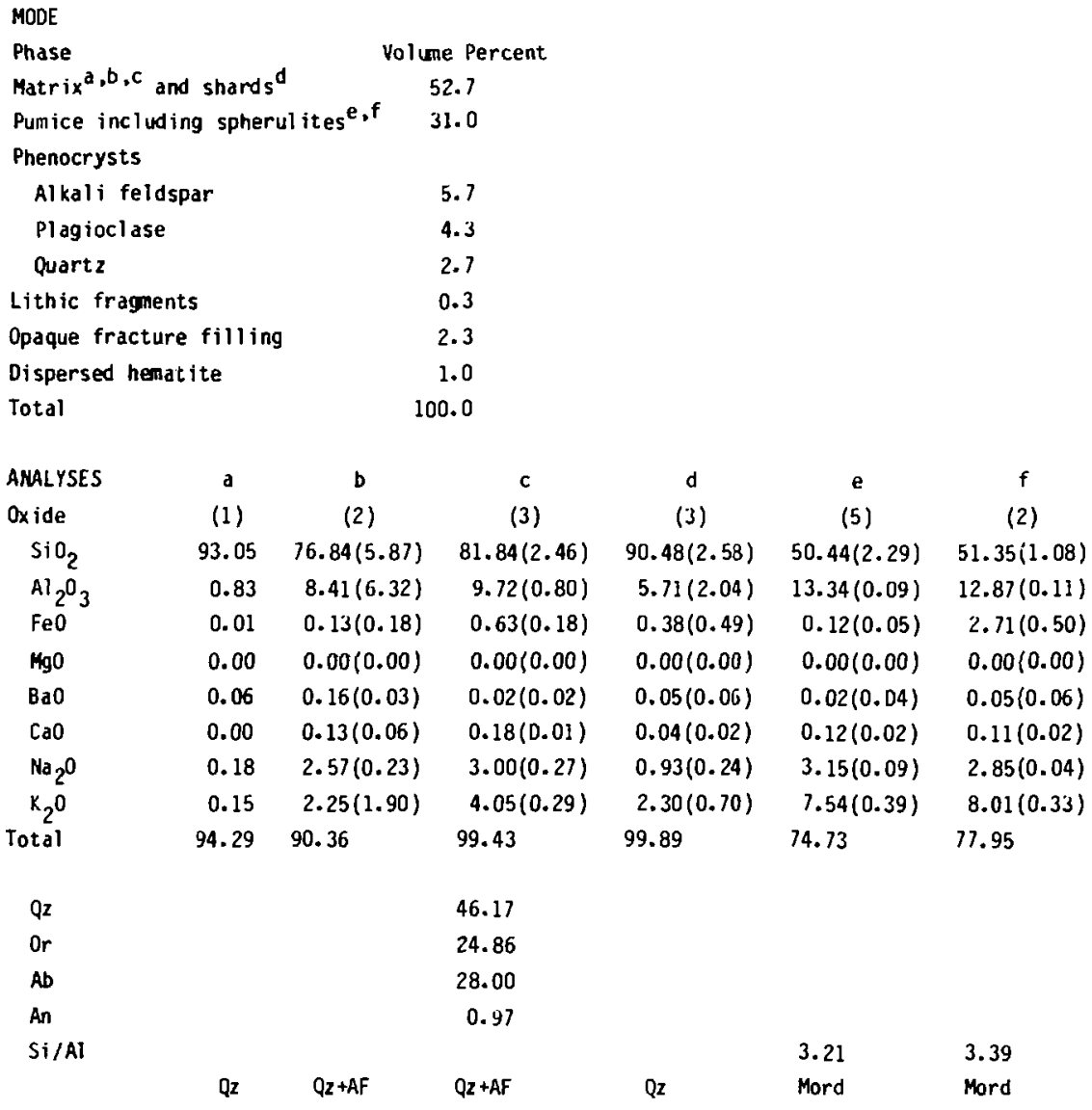


YM-47 (636,3): Devitrified\{?) nonwelded vitric-crystal tuff. This rock consists mostly of relict shards with occasional compacted relict punice pyroclasts. All pyroclasts have been replaced by finely crystalline (<2 $\mu m$ diam) grains of clinoptilolite.

Abundant phenocrysts include rounded quartz, plagioclase, sanidine $\left(0 r_{48}\right)$, and anarthoclase $\left(0 r_{26}\right)$. $L$ i $t h$ i fragments include siltstone clasts up to $5 \mathrm{~mm}$ long and rounded fragments of welded tuff.

MODE

Phase

Matrix ${ }^{a, b}$ and shards

Pumice, including vug lining

Phenocrysts

Sanidine and

anorthoclase

Plagioclase

Lithic fragments

Siltstone

Welded tuff

rotal

$\begin{array}{lc}\text { ANALYSES } & \text { a } \\ \text { Oxide } & (2)\end{array}$

$\mathrm{SiO}_{2} \quad 68.91(0.12)$

$\mathrm{Al}_{2} \mathrm{O}_{3} \quad 10.56(0.45)$

$\mathrm{FeO} \quad 0.01(0.01)$

MgO $0.11(0.15)$

$\mathrm{BaO} \quad 0.03(0.02)$

$\mathrm{CaO} \quad 3.07(0.26)$

$\mathrm{Na}_{2} \mathrm{O} \quad 1.05(0.01)$

$\mathrm{K}_{2} \mathrm{O} \quad 0.89(0.13)$

Total

84.63

$\mathrm{Si} / \mathrm{Al}$
Volume Percent

$$
64.3
$$

17.7

8.0

5.0

4.0

1.0

100.0

\section{b}

(3)

$59.18(0.83)$

$9.45(0.48)$

$0.33(0.06)$

$0.05(0.02)$

$0.00(0.00)$

$1.34(0.05)$

$0.87(0.09)$

$4.98(0.93)$

76.20

5.31

$\mathrm{Cl}$ in
(5)

$66.62(0.09)$

$11.69(0.06)$

$0.03(0.04)$

$0.63(0.03)$

$0.04(0.02)$

$3.86(0.05)$

$0.26(0.03)$

$1.07(0.17)$

84.20

4.84

$\mathrm{Cl}$ in

$\begin{array}{lll}5.54 & 4.84 \\ \text { Clin } & \text { Clin } & \text { Clin }\end{array}$


YM-48 (644.2): Altered slightly welded vitric tuff. This slightly altered tuff consists of 1-4 mm long pumice pyracla ts in a matrix of 10 um- $0.6 \mathrm{~mm}$ long shards and finely crystalline ( $1-8$ um diam) colorless cementing phases. Pyroclast interiors are still glassy; rims and vesicle walls are altered to a colorless, 3-5 um long fibrous phase which grows perpendicular to these boundaries.

Numerous phenocrysts include plagioclase $\left(A n_{8}\right)$, sanidine $\left(0 r_{53}\right)$, rounded quartz, orthopyroxene, biotite, and magnetite. Randomly oriented 15-20 $\mu \mathrm{m}$ wide fractures are occasionally filled with a zeolite.

\begin{tabular}{|c|c|c|c|c|}
\hline \multicolumn{5}{|l|}{ MODE } \\
\hline Pliase & & Volume Percent & & \\
\hline Matrix & & 39.1 & & \\
\hline Shards ${ }^{d}$ & & 26.9 & & \\
\hline Punice ${ }^{b}$ & & 24.2 & & \\
\hline \multicolumn{5}{|l|}{ Pheлосrysts } \\
\hline Plagioclase & & 4.2 & & \\
\hline Sanidine & & 3.4 & & \\
\hline Opãques & & 0.4 & & \\
\hline Pyroxene & & $\operatorname{tr}$ & & \\
\hline Biotite & & $\operatorname{tr}$ & & \\
\hline Quartz & & $\operatorname{tr}$ & & \\
\hline Lithic fragment & & 1.4 & & \\
\hline Fracture fillis & & 0.4 & & \\
\hline Total & & 100.0 & & \\
\hline ANALYSES & a & b & c & d \\
\hline Oxide & (3) & (2) & (2) & (6) \\
\hline $\mathrm{SiO}_{2}$ & $78.14(0.83)$ & $75.14(0.72)$ & $69.24(1.93)$ & $76.54(0.59)$ \\
\hline $\mathrm{Al}_{2} \mathrm{O}_{3}$ & $12.48(0.46)$ & $11.40(0.06)$ & $11.16(0.18)$ & $11.55(0.11)$ \\
\hline $\mathrm{FeO}$ & $0.60(0.05)$ & $0.29(0.05)$ & $0.26(0.04)$ & $0.39(0.08)$ \\
\hline $\mathrm{MgO}$ & $0.03(0.03)$ & $0.00(0.00)$ & $0.43(0.04)$ & $0.00(0.00)$ \\
\hline $\mathrm{BaO}$ & $0.00(0.00)$ & $0.00(0.04)$ & $0.00(0.04)$ & $0.00(0.10)$ \\
\hline $\mathrm{CaO}$ & $1.06(0.54)$ & $0.87(0.10)$ & $2.84(0.09)$ & $0.23(0.04)$ \\
\hline $\mathrm{Na}_{2} \mathrm{O}$ & $2.50(0.89)$ & $3.11(0.16)$ & $0.63(0.09)$ & $2.31(0.06)$ \\
\hline $\mathrm{K}_{2} \mathrm{O}$ & $4.49(0.54)$ & $4.59(0.22)$ & $0.84(0.10)$ & $4.02(0.29)$ \\
\hline Total & 99.29 & 95.40 & 85.40 & 95.04 \\
\hline$Q \mathbf{z}$ & 42.68 & 37.22 & & 48.77 \\
\hline $0 r$ & 28.04 & 29.03 & & 26.66 \\
\hline$A \mathrm{~b}$ & 23.73 & 29.90 & & 23.28 \\
\hline An & 5.56 & 3.84 & & 1.28 \\
\hline $\mathrm{Si} / \mathrm{Al}$ & & & 5.26 & \\
\hline & $Q z+K A F$ & 'G!ass' & clin & 'Glass' \\
\hline
\end{tabular}


YM-49 (676.8): Altered nonwelded vitric tuff. This rock is similar in many respects to YM-48, but the alteration is more advanced. Pyroclasts are completely altered to a colorless, $10-15$ um long fibrous phase. In contrast to $\mathrm{YM}-48$, where most pyroclast voids were vesizles, portions of some clasts in YM-49 have been dissolved to form vugs These solution vugs and vesicles are lined or filled with colorless, euhedral tithular, 15-25 pm long (clinop:ilolite crystals).

Plagioclase $\left(\mathrm{An}_{10}\right)$ and sanidine $\left(0 \mathrm{r}_{55}\right)$ are the dominant phenocrysts; quartz, magnetite, and biotite are also present. Glomerocrysts up to $2 \mathrm{~mm}$ in diameter al so occur. Lithic fragments consist of welded tuff clasts up to $3 \mathrm{~mm}$ in diameter.

$\begin{array}{lc}\text { MODE } & \text { Volume Percent } \\ \text { Phase } & 36.9 \\ \text { Matrix } & \\ \text { Shards } & 23.8 \\ \text { Walls } & \\ \text { Void lining } & \text { and } \\ \quad \text { filling } & \\ \text { Pumice } & 3.5 \\ \text { Phenocrysts } & 22.0 \\ \text { Plagioclase } & \\ \text { Sanidine } & 3.5 \\ \text { Quartz } & 3.0 \\ \text { Biotite } & 0.6 \\ \text { Opaques } & \mathrm{tr} \\ \text { Lithic fragments } & 0.5 \\ \text { Voids } & 3.4 \\ \text { Total } & 2.8\end{array}$

$\begin{array}{ccccc}\text { ANALYSES } & \mathrm{a} & \mathrm{b} & \mathrm{c} & \mathrm{d} \\ \text { Oxide } & (6) & (3) & (6) & (5) \\ \mathrm{SiO}_{2} & 69.67(0.13) & 64.99(1.20) & 62.61(0.71) & 66.21(0.30) \\ \mathrm{Al}_{2} \mathrm{O}_{3} & 10.36(0.46) & 11.36(0.60) & 11.13(0.37) & 10.92(0.57) \\ \mathrm{Fe} 0 & 0.76(0.11) & 0.01(0.02) & 0.00(0.02) & 0.00(0.00) \\ \mathrm{MgO} & 0.25(0.02) & 0.60(0.04) & 0.45(0.04) & 0.24(0.08) \\ \mathrm{Ba0} & 0.00(0.00) & 0.00(0.00) & 0.00(0.02) & 0.00(0.00) \\ \mathrm{CaO} & 2.03(0.34) & 3.72(0.04) & 3.55(0.42) & 3.24(0.51) \\ \mathrm{Na}{ }_{2} \mathrm{O} & 0.93(0.06) & 0.76(0.05) & 0.33(0.16) & 0.49(0.11) \\ \mathrm{K}_{2} \mathrm{O} & 3.39(0.08) & 1.40(0.04) & 1.10(0.11) & 0.99(0.17) \\ \mathrm{Total} & 87.39 & 82.84 & 79.17 & 82.09 \\ & & & & \\ \mathrm{Si} / \mathrm{Al} & 5.71 & 4.85 & 4.77 & 5.14 \\ & \mathrm{Clin} & \mathrm{Clin} & \mathrm{Clin} & \mathrm{Clin}\end{array}$


M-50 (702.4): Altered nonwelded vitric-crystal tuff. This rock is similar texturally and mineralogically to YM-49. Major differences are: 1) lithic fragments are all sligntly elongate to rounded siltstone clasts, occasionally stained with hematite; 2) relict shards are larger, having been broken from larger, having been broken from larger vesicles; and 3) oxidized amphibole is the mafic phenocryst rather than biotite.

\section{MOOE}

Phase

Matrix $x^{a, b}$

Coarse shards ${ }^{c}$, including

coarse crystalline phases ${ }^{d}$

Punice

Phenociysts

Sanidine

Plagioclase

Quartz

Lithic fragments

Siltstone

Helded tuff

Hemate reflacing amphibole

Total

\section{ANALYSES}

Oxide

$\mathrm{SiO}_{2}$

$\mathrm{Al}_{2} \mathrm{O}_{3}$

$\mathrm{FeO}$

$\mathrm{MgO}$

BaO

$\mathrm{CaO}$

$\mathrm{Na}_{2} \mathrm{O}$

$\mathrm{K}_{2} \mathrm{O}$

Total

Qz

Or

Ab

An

Si/Al
Volume Perce.tt

$38 . n$

29.0

18.0

4.0

3.7

1.7

2.0

3.0

0.7

100.1

$\begin{array}{rcccc}a & b & c & d & \mathrm{e} \\ (1) & (1) & (2) & (2) & (2) \\ 68.80 & 75.98 & 66.47(0.26) & 76.31(14.74) & 63.72(0.42) \\ 7.67 & 8.97 & 11.93(0.21) & 12.04(0.37) & 17.13(0.02) \\ 0.40 & 0.46 & 0.01(0.02) & 0.00(0.00) & 0.68(0.09) \\ 0.00 & 0.01 & 0.13(0.01) & 0.11(0.06) & 0.00(0.00) \\ 0.12 & 0.05 & 0.11(0.06) & 0.03(0.01) & 0.16(0.04) \\ 0.68 & 1.10 & 3.93(0.04) & 4.21(0.09) & 0.14(0.02) \\ 0.43 & 0.52 & 0.83(0.12) & 0.45(0.13) & 2.81(0.04) \\ 10.59 & 12.39 & 1.56(0.14) & 1.38(0.08) & 11.09(0.44) \\ 88.70 & 99.49 & 84.97 & 94.53 & 95.73 \\ & & & & \\ & 42.80 & & 62.33 & 3.83 \\ & 57.20 & & 9.27 & 68.69 \\ & 0.00 & & 4.59 & 26.45 \\ & 0.00 & & 23.81 & 1.03\end{array}$

Mont Qz+KAF Mix Clin+Qz KAF 
M-51 (710.6): Altered non-welded vitric-crystal tuff. This rock is similar texturaliy and mineralogically to YM-49 and YM-50. Differences are: 1) fewer phenocrysts, 2) fewer punices, 3) fewer lithics, and 4) biotite is a phenocryst.

\begin{tabular}{|c|c|c|c|}
\hline \multicolumn{4}{|l|}{ MODE } \\
\hline Phase & \multicolumn{3}{|c|}{ Volume Percent } \\
\hline Matrix & \multicolumn{3}{|c|}{60.0} \\
\hline Shards ${ }^{b}$ & \multicolumn{3}{|c|}{29.3} \\
\hline Punice ${ }^{c}$ & \multicolumn{3}{|c|}{2.7} \\
\hline \multicolumn{4}{|l|}{ Phenocrysts } \\
\hline Plagioclase & \multicolumn{3}{|c|}{4.0} \\
\hline Alkali felds & \multicolumn{3}{|c|}{1.7} \\
\hline Quartz & \multicolumn{3}{|c|}{0.3} \\
\hline \multicolumn{4}{|c|}{ Lithic fragments } \\
\hline Siltstone & \multicolumn{3}{|c|}{1.3} \\
\hline Helded tuff & \multicolumn{3}{|c|}{0.7} \\
\hline Total & \multicolumn{3}{|c|}{100.0} \\
\hline ANGL YSES & a & $b$ & c \\
\hline Oxide & (2) & (5) & (2) \\
\hline $\mathrm{SiO}_{2}$ & $65.20(3.66)$ & $65.91(1.56)$ & $67.11(0.26)$ \\
\hline $\mathrm{Al}_{2} \mathrm{O}_{3}$ & $10.79(0.93)$ & $11.48(0.29)$ & $11.31(0.04)$ \\
\hline $\mathrm{FeO}$ & $1.89(0.71)$ & $0.00(0.00)$ & $0.00(0.02)$ \\
\hline $\mathrm{Mg} 0$ & $0.53(0.08)$ & $0.28(0.21)$ & $0.08(0.04)$ \\
\hline $\mathrm{BaO}$ & $0.07(0.10)$ & $0.08(0.10)$ & $0.15(0.00)$ \\
\hline $\mathrm{CaO}$ & $1.91(0.25)$ & $3.41(0.40)$ & $3.37(0.13)$ \\
\hline $\mathrm{Na}_{2} \mathrm{O}$ & $0.77(0.06)$ & $0.98(0.13)$ & $0.93(0.07)$ \\
\hline $\mathrm{k}_{2} \mathrm{O}$ & $1.93(0.35)$ & $0.60(0.21)$ & $0.35(0.02)$ \\
\hline Total & 81.18 & 82.74 & 83.36 \\
\hline $\mathrm{Si} / \mathrm{Al}$ & 5.13 & 4.87 & 5.03 \\
\hline & $\mathrm{Clin}$ & Clin & $\mathrm{Clin}$ \\
\hline
\end{tabular}


Bullfrog Member of the Crater Flat Tuff

YM-52 (119.8): Devitrified welded vitric-crystal tuff. This rock is nearly identical to YM-54 both texturally and mineralogically with the exception of fewer phenocrysts ( $\rho$ lagioclase $\left(A n_{16}\right)$, quartz, biotite. and magnetite).

\begin{tabular}{|c|c|c|}
\hline \multicolumn{3}{|l|}{ MODE } \\
\hline Phase & & Yolume $P$ \\
\hline \multicolumn{3}{|l|}{ Matrix } \\
\hline \multicolumn{2}{|c|}{ Fine crystalline } & 38.3 \\
\hline \multicolumn{2}{|c|}{ Medium crystalline $e^{a, b}$} & 30.7 \\
\hline \multicolumn{3}{|l|}{ Pumice } \\
\hline \multicolumn{2}{|c|}{ Coarse crystalline } & 5.2 \\
\hline \multicolumn{2}{|c|}{ Fibrous/spherulitic } & 11.3 \\
\hline \multicolumn{3}{|c|}{ Phenocrysts } \\
\hline \multicolumn{2}{|c|}{ Alkali feldspar } & 7.7 \\
\hline \multicolumn{2}{|c|}{ Plagioclase } & 4.0 \\
\hline \multicolumn{2}{|l|}{ Quartz } & 0.3 \\
\hline \multicolumn{2}{|l|}{ Biotite } & $\mathrm{tr}$ \\
\hline \multicolumn{2}{|l|}{ Opaques } & $\mathrm{tr}$ \\
\hline \multicolumn{2}{|l|}{ Voids } & 2.4 \\
\hline \multicolumn{2}{|l|}{ Total } & 100.0 \\
\hline ANALYSES & a & b \\
\hline oxide & (2) & (1) \\
\hline $\mathrm{SiO}_{2}$ & 64.75 & 92.98 \\
\hline \multirow{2}{*}{$\begin{array}{l}\mathrm{Al}_{2}{ }^{\mathrm{O}} 3 \\
\mathrm{Fe} 0\end{array}$} & 16.97 & 3.87 \\
\hline & 0.09 & 0.00 \\
\hline $\mathrm{MgO}$ & 0.00 & 0.00 \\
\hline $\mathrm{BaO}$ & 0.08 & 0.00 \\
\hline$C \mathrm{~d} 0 \quad 0.25$ & 0.03 & \\
\hline Na, 0 & 3.59 & 0.54 \\
\hline$K_{2} \mathrm{O}$ & 10.50 & 1.89 \\
\hline Total & 96.23 & 99.31 \\
\hline$Q z$ & 4.03 & \\
\hline Or & 64.25 & \\
\hline$A b$ & 31.72 & \\
\hline \multirow[t]{2}{*}{ in } & 0.00 & \\
\hline & KAF & Qz \\
\hline
\end{tabular}


YM-53 (737.5): Devitrified melded vitric-crystal tuff. All phases are identical to those in YM-54. Differences are 1) fewer phenocrysts, and 2) finer-grained crystalline mosaics.

\begin{tabular}{|c|c|c|c|}
\hline \multicolumn{4}{|l|}{ MODE } \\
\hline \multicolumn{2}{|l|}{ Phase } & Volume Percent & \\
\hline \multicolumn{4}{|l|}{ Matrixa } \\
\hline \multicolumn{2}{|c|}{ Fine crystalline } & 31.9 & \\
\hline \multicolumn{2}{|c|}{ Mediun crystalline } & 42.4 & \\
\hline \multicolumn{4}{|l|}{ Pumice } \\
\hline \multicolumn{2}{|c|}{ Coarse crystalline $b, c$} & 3.0 & \\
\hline \multicolumn{2}{|c|}{ Fibrous/spherulitic } & 4.3 & \\
\hline \multicolumn{4}{|c|}{ Phenocrysts } \\
\hline \multicolumn{2}{|c|}{ Alkali feldspar } & 9.5 & \\
\hline \multicolumn{2}{|c|}{ Plagioclase } & 5.9 & \\
\hline \multicolumn{2}{|l|}{ Quartz } & 1.6 & \\
\hline \multicolumn{2}{|l|}{ Biotite } & $\operatorname{tr}$ & \\
\hline \multicolumn{2}{|l|}{ Cpaques } & $\mathrm{tr}$ & \\
\hline \multicolumn{2}{|l|}{ Voids } & 1.4 & \\
\hline \multicolumn{2}{|l|}{ Total } & 100.0 & \\
\hline \multicolumn{2}{|l|}{ ANALYSES } & $b$ & c \\
\hline $0 x$ ide & (2) & (6) & (2) \\
\hline $\mathrm{SiO}_{2}$ & $52.09(2.34)$ & $94.27(1.37)$ & $65.20(0.28)$ \\
\hline $\mathrm{Al}_{2} \mathrm{O}_{3}$ & $12.66(1.34)$ & $0.95(0.64)$ & $17.78(1.21\}$ \\
\hline $\mathrm{Fe} 0$ & $1.27(0.20)$ & $0.03(0.03)$ & $0.07(0.01)$ \\
\hline $\mathrm{MgO}$ & $0.02(0.03)$ & $0.00(0.00)$ & $0.00(0.00)$ \\
\hline$B a 0$ & $0.03(0.01)$ & $0.12(0.08)$ & $0.53(0.54)$ \\
\hline $\mathrm{CaO}$ & $0.32(0.24)$ & $0.01(0.02)$ & $0.19\{0.11\}$ \\
\hline $\mathrm{Na}_{2} \mathrm{O}$ & $4.27(1.39)$ & $0.23(0.14)$ & $4.17(2.31)$ \\
\hline$k_{2} 0$ & $\because 35(1.85)$ & $0.12(0.11)$ & $9.58(3.03)$ \\
\hline Total & 75.01 & 95.73 & 97.52 \\
\hline \multicolumn{2}{|l|}{ Qz } & & 3.27 \\
\hline \multicolumn{2}{|l|}{ Or } & & 57.30 \\
\hline \multicolumn{2}{|l|}{$A D$} & & 37.92 \\
\hline \multirow[t]{2}{*}{ An } & & & 1.52 \\
\hline & Mont & $Q z$ & KAF \\
\hline
\end{tabular}


YM-54 (759.3): Devitrified welded vitric-crystal tuff. In hand specimen this appears to be a welded tuff; however, in thin section no relict pyroclasts have been preserved. There is only a fabric of lenticular zones of coarsely crystal1 ine phases that may have been welded pyroclasts. Most of the rock consists of colorless to tan, 2-20 um diameter alkali feldspar and quartz crystals. Siattereo thrnughout this 'matrix' are irregular patches of more coarsely crystalline (150-400 um diameter) alkali feldspar and quart.: grains; the larger of these are sometimes roughly rimed by spherulites.

Phenocrysts include sanidine $\left(0 r_{62-64}\right)$ and quartz with quartz overgrowths, oxidized biotite, plagioclase, and magnetite. Xenocrysts of mafic phases altered to phlogopite and hematite also occur.

MODE

Phase

Matrix $a, b$

Volume Percint

Pumice

Coarse crystalline ${ }^{c} \quad 36.1$

Fibrous/spherulitic $\quad 8.8$

Phenocrysts

Sanidine $\quad 10.0$

Quartz 4.1

Plagioclase 2.3

Biotite 1.2

Opaques 0.2

Phlogopite plus hematite $\quad 1.2$

other 0.2

Total 99.9

$\begin{array}{cccc}\text { ANALYSES } & \mathrm{a} & \mathrm{b} & \mathrm{c} \\ \text { Oxide } & (4) & (1) & (2) \\ \mathrm{SiO}_{2} & 68.45(1.94) & 96.16 & 66.32(1.34) \\ \mathrm{Al}_{2} \mathrm{O}_{3} & 18.45(0.74) & 0.45 & 22.61(0.55) \\ \mathrm{FeO} & 0.13(0.14) & 0.00 & 0.12(0.02) \\ \mathrm{MgO} & 0.13(0.14) & 0.00 & 0.00(0.00) \\ \mathrm{BaO} & 0.00(0.00) & 0.00 & 0.00(0.06) \\ \mathrm{CaO} & 0.55(0.59) & 0.00 & 3.94(0.86) \\ \mathrm{Na} 2 \mathrm{O} & 4.65(2.45) & 0.12 & 0.89(0.54) \\ \mathrm{K}_{2} \mathrm{O} & 8.46(4.38) & 0.04 & 0.99(0.27) \\ \text { Total } & 100.69 & 96.77 & 100.88\end{array}$

$\begin{array}{lrrr}\text { Qz } & 7.05 & & 12.86 \\ \text { Or } & 49.18 & 5.84 \\ \text { AD } & 41.09 & & 61.78 \\ \text { An } & 2.68 & & 19.52 \\ & \text { KAF } & \text { Mz } & \text { NaAF }\end{array}$

